University of Louisville

ThinkIR: The University of Louisville's Institutional Repository

Electronic Theses and Dissertations

$5-2017$

\title{
Late Magdalenian lithic technological organization at Lapa do Picareiro, central Portugal.
}

Melissa Jean Holst

University of Louisville

Follow this and additional works at: https://ir.library.louisville.edu/etd

Part of the Archaeological Anthropology Commons

\section{Recommended Citation}

Holst, Melissa Jean, "Late Magdalenian lithic technological organization at Lapa do Picareiro, central Portugal." (2017). Electronic Theses and Dissertations. Paper 2720.

https://doi.org/10.18297/etd/2720

This Master's Thesis is brought to you for free and open access by ThinkIR: The University of Louisville's Institutional Repository. It has been accepted for inclusion in Electronic Theses and Dissertations by an authorized administrator of ThinkIR: The University of Louisville's Institutional Repository. This title appears here courtesy of the author, who has retained all other copyrights. For more information, please contact thinkir@louisville.edu. 


\title{
LATE MAGDALENIAN LITHIC TECHNOLOGICAL ORGANIZATION AT LAPA DO PICAREIRO, CENTRAL PORTUGAL
}

\author{
By \\ Melissa Jean Holst \\ B.A., University of Louisville, 2013

\begin{abstract}
A Thesis
Submitted to the Faculty of the

College of Arts and Sciences of the University of Louisville in Partial Fulfillment of the Requirements for the Degree of
\end{abstract}

Master of Arts in Anthropology

Department of Anthropology

University of Louisville

Louisville, Kentucky

May 2017 



\section{LATE MAGDALENIAN LITHIC TECHNOLOGICAL ORGANIZATION AT LAPA DO PICAREIRO, CENTRAL PORTUGAL BY \\ Melissa Jean Holst \\ B.A., University of Louisville, 2013 \\ A Thesis Approved on \\ March 31, 2017}

By the following Thesis Committee:

Dr. Jonathan A. Haws, Thesis Director

Dr. Telmo J. R. Pereira

Dr. Amanuel Y. Beyin 
For Lana and Henry 


\section{ACKNOWLEDGEMENTS}

There were many people involved in the development, execution, and production of this Master's thesis. I would first like to extend personal thanks to the four individuals whom I have relied on so heavily throughout my time working on this thesis:

Dr. Jonathan Haws (University of Louisville) has been my primary mentor and advisor since I was an Undergraduate at the University of Louisville. It was at his invitation that I was provided the opportunity to participate in the ongoing excavations at Lapa do Picareiro in central Portugal. His leadership, advice, guidance, and encouragement have been instrumental in my academic and developing professional success. It is hard to really express the extent to which I owe all that I have learned and experienced in archaeology to him.

There is then Dr. Telmo Pereira (University of Algarve). I have had the pleasure of working in the laboratory at the University of Algarve and in the field at Lapa do Picareiro with him. While being one of my mentors he is also a dear friend who has provided me with an innumerable amount of advice,

encouragement, brutally honest criticism, and support throughout the past couple years. If it wasn't for his patience, willingness to teach me, and objective eye for editing, I couldn't have completed this thesis so successfully. I look forward to many more years of friendship and hopefully future collaboration with him. 
Over the past year, I have had the opportunity to work Dr. Amanuel Beyin (University of Louisville) in the archaeology laboratory, at the University of Louisville, and in the classroom both as student and assistant. He has provided me with countless hours of guidance, constructive criticism, encouragement, and honest advice. I look forward to growing our professional relationship in the coming months and hopefully years.

And last but not least, there is Philip DiBlasi (University of Louisville). He has provided me with hours and hours of advice, stories, laughter, consolation, and encouragement over the past year. He has been such an amazing mentor and friend to me. I honestly cannot imagine what I would have done without him.

I cannot express enough how much I owe to these four. Anyone who gets to work with any of them (let alone all of them) should consider themselves extremely fortunate. I know I do.

Next I would like to thank all the groups that have help fund my research for this thesis over the years. The funding for this project was generously granted by the University of Louisville Anthropology Department, the University of Louisville Portuguese Studies Program, the University of Louisville Graduate Student Council, and the University of Louisville Graduate Network of the Arts and Sciences. Special thanks to the University of Algarve and ICArEHB for providing me access to and a place to work with the assemblage. Without the support provided by these groups, this thesis could not have been done. Thank you so very much 
I also want to thank my friends and colleagues who have helped me during this journey. Forrest Melvin, Mallory Cox, Cassandra Penley, and Krysta Wilham, thank you from the bottom of my heart. You four have been there for me on this journey like no others. The network of support, commiseration, accountability, celebration, and friendship that I have found in you ladies is something I will always hold dear. I really couldn't have done this without you all. Thank you.

Next, I would like to thank all of my family. Thank you all for all the love, support, and encouragement you have given me on this journey. It is because of you all that this dream became a reality for me. Words really do not do justice to how thankful I am for all that all of you have done for me and continue to do.

Last, but certainly not least, I want to thank my amazing husband, Kyle Holst, for his unconditional love, unwavering support, and for never letting me give up on myself or this thesis project. Thank you for enduring all the months of me being away for field work and analysis, never letting the distance or the duration of my absence and focus affect the amazing life we have together, and for always celebrating date night with me, even when I am an ocean away. More than anyone else, this thesis project was possible because of you. Thank you, I love you so much. 


\title{
ABSTRACT \\ LATE MAGDALENIAN LITHIC TECHNOLOGICAL ORGANIZATION AT LAPA DO PICAREIRO, CENTRAL PORTUGAL
}

\author{
Melissa J. Holst
}

March 31, 2017

Lapa do Picareiro, a cave located in Portuguese Estremadura, contains continuous deposits dated to the Late Pleistocene. As one of the highest elevation Upper Paleolithic sites currently known in Portugal, questions are raised about the function of the site during this time. This thesis presents a comprehensive analysis of the lithic assemblage recovered from the Late Magdalenian layer of $F / G(13,442$ to 14,011 cal BP). The data generated from this study, when looked at in conjunction with the previously analyzed faunal assemblage, helps to provide a broader understanding of the site's function during the Late Magdalenian. The analysis focuses on raw material preference and use, representation of reduction phases, and typologies present in the assemblage. These data are then compared with other contemporaneous sites in the region to see what, if any, inferences can be drawn about location and site function. This is important because this work ultimately contextualizes the observed patterns found in the lithic assemblage in the broader context of the Late Magdalenian in southern Iberia. 


\section{TABLE OF CONTENTS}

ACKNOWLEDGMENTS iv

ABSTRACT vii

LIST OF TABLES $\quad x i$

LIST OF FIGURES Xiii

CHAPTER I: INTRODUCTION

CHAPTER II: BACKGROUND AND HISTORY OF INVESTIGATION 4

Upper Paleolithic in Portugal 5

Portuguese Estremadura and the Magdalenian Period 6

The Magdalenian Lithic Assemblages of Estremadura $\quad 7$

History and Chronology of the Site 9

CHAPTER III: CLIMATE, PALEO-ENVIRONMENT, SUBSISTENCE, AND

MOBILITY DURING THE LATE PLEISTOCENE IN PORTUGAL 15

Climatic Events and their Impact on the Paleo-Environment 16

$\begin{array}{ll}\text { Late Pleistocene Mobility and Subsistence } & 19\end{array}$

Technological Adaptation and Raw Material Availability 23

Raw Material Availability 25

CHAPTER IV: PREVIOUS ANALYSIS OF LITHIC MATERIALS FROM

LAPA DO PICAREIRO 28 
Work by Nuno Bicho

Work by Telmo Pereira 30

Work by Carolina Mendonça 32

CHAPTER V: METHODOLOGY 33

General Analysis 34

Technological Definitions 34

$\begin{array}{ll}\text { Typological Definitions } & 38\end{array}$

CHAPTER VI: NEW DATA ON LITHIC TECHNOLOGICAL ORGANIZATION

AT LAPA DO PICAREIRO 41

Layer F/G: Archaeological Context 42

Layer F/G: Artifact Density $\quad 44$

Layer F/G: Cores 46

Layer F/G: Blanks $\quad 51$

Layer F/G: Burin Spalls $\quad 55$

Layer F/G: Retouched Tools $\quad 57$

CHAPTER VII: DISCUSSION, CONCLUSIONS, AND FUTURE RESEARCH

$\begin{array}{ll}\text { OPPORTUNITIES } & 70\end{array}$

$\begin{array}{ll}\text { Analysis Interpretation } & 70\end{array}$

Discerning Site Function from the Assemblage Analysis 74

$\begin{array}{ll}\text { Regional Site Comparisons } & 78\end{array}$

Conclusion and Future Research Opportunities 84

$\begin{array}{lr}\text { REFERENCES } & 87\end{array}$

APPENDIX I: SITE CHRONOLOGY 96 
APPENDIX II: QUANTITATIVE ANALYSIS 98

APPENDIX III: ASSEMBLAGE ANALYSIS 100

APPENDIX IV: IMAGERY APPENDIX 104

$\begin{array}{ll}\text { CURRICULUM VITAE } & 107\end{array}$ 


\section{LIST OF TABLES}

Table 3.1: Layer F/G NIS from faunal data 23

Table 6.1: Layer F/G Assemblage Inventory 43

Table 6.2: Inventory of Cores by Raw Material 46

Table 6.3: Inventory of Cores Types in Chert 47

Table 6.4: Inventory of Core Types in Quartz 48

Table 6.5: Inventory of Core Types in Quartzite 48

Table 6.6: Inventory of Burin Spalls by Raw Material 56

Table 6.7: Retouched Tool Inventory 58

Table 6.8: Inventory of Backed Bladelets 58

Table 6.9: Inventory of Backed Bladelet Typologies 59

Table 6.10: Inventory of Burins $\quad 60$

Table 6.11: Inventory of Burin Typologies 61

Table 6.12: Inventory of Composite Tools 62

Table 6.13: Inventory of Composite Tool Typologies 62

Table 6.14: Inventory of Denticulates 63

Table 6.15: Inventory of Denticulate Typology 63

Table 6.16: Inventory of Notches $\quad 64$

Table 6.17: Inventory of Notch Typology 64

Table 6.18: Inventory of Perforators 65 
Table 6.19: Inventory of Perforator Typology 65

Table 6.20: Inventory of Side Scrapers 66

Table 6.21: Inventory of Side Scraper Typology 66

Table 6.22: Inventory of Thick Endscrapers $\quad 67$

Table 6.23: Inventory of Thick Endscraper Typologies 68

Table 6.24: Inventory of Thin Endscrapers 68

Table 6.25: Inventory of Thin Endscraper Typologies 69

Table 6.26: Inventory of Truncations 69

Table 6.27: Inventory of Truncation Typologies $\quad 70$

Table 7.1: Raw Material Assemblage Number, Weight, \& Percent $\begin{array}{ll}\text { Representation } & 71\end{array}$

Table 7.2: Raw Material Representation by number of Artifacts/Retouched $\begin{array}{ll}\text { Tools } & 73\end{array}$

Table 7.6: Inter-site Assemblage Comparison Ratios 83 


\section{LIST OF FIGURES}

Figure 2.1: Map of the Iberian Peninsula $\quad 10$

Figure 2.2: Western Face of the Serra d'Aire Mountains 11

Figure 2.3: Excavation Inside Lapa do Picareiro 13

Figure 2.4: Profile View of Lapa do Picareiro 13

Figure 2.5: Interior Plan of the Cave 14

Figure 3.1: Climatic Events that Occurred During the Late Pleistocene 20

Figure 6.1: Stratigraphic Sequence of Late Magdalenian Layers of Picareiro 42

Figure 6.2: Exposing of the Layer F/G Hearth 44

Figure 6.3: Top of the Exposed Layer F/G Hearth 44

Figure 6.4: Relative Density of Artifacts by Raw Material in Layer F/G 45

Figure 6.5: Relative Density of All Raw Material Types in Layer F/G 46

Figure 6.6: Average Core Size $\quad 49$

Figure 6.7: Core Volume to Cortical Presence Comparison 50

Figure 6.8: Average Flake Blank Size by Raw Material 51

Figure 6.9: Relative Distribution of Blank Types 52

Figure 6.10: Distribution of Average Flake Blank Size 53

Figure 6.11: Average Blade \& Bladelet Size Distribution 54

Figure 6.12: Frequency of Elongated Quartzite Blanks 55

Figure 6.13: Frequency of Elongated Quartz Blanks 55 
Figure 6.14: Frequency of Elongated Chert Blanks

Figure 6.15: Average Bladelet \& Burin Spall Size Distribution

Figure 7.1: Raw Material Distribution by Number

72

Figure 7.2: Raw Material Distribution by Weight

73

Figure 7.3: Location of CPM in Relation to Coelhos \& Picareiro

80

Figure 7.4: Locations of Coelhos in Relation to CPM \& Picareiro

81

Figure 7.5: Location of Picareiro in Relation to Coelhos \& CPM

81

Figure 7.6: Inter-site Assemblage Representation Comparison

82

Figure 7.7: Cluster Analysis of Site Assemblage Representations

84 


\section{CHAPTER I:}

\section{INTRODUCTION AND RESEARCH OBJECTIVES}

In recent years, an influx of new information has led to a better understanding of hunter-gatherer raw material use and lithic technological adaptation during the latter half of the Upper Paleolithic in the Portuguese Estremadura (Gameiro 2012, Pereira 2010, Bicho 2000). In particular, there are now 12 sites with layers radiometrically dated to the Magdalenian, a time period spanning from roughly 20 to $10 \mathrm{ka}$ cal BP. The majority of those dates came from the sites of Cabeço do Porto Marinho (CPM) (Marks et al. 1994), Lapa do Picareiro (Bicho et al. 2000), Lapa do Suão (Zilhão 1997a; Haws 2003), and Lapa dos Coelhos (Almeida et al. 2004); This allowed for a more refined and comprehensive understanding of the Magdalenian period in Portugal (Bicho and Haws 2012). The characterization of Magdalenian lithic technology derives from detailed analysis of CPM and Lapa dos Coelhos combined with preliminary results from Picareiro and Suão (Zilhão 1997a, Bicho 2000).

Using principles adopted from Foraging Theory, the purpose of this thesis is to form inferences about Magdalenian lithic technological organization through a detailed analysis of the Late Magdalenian lithic assemblage from Lapa do Picareiro. Resulting in the introduction of this crucial site to the discussion of the 
human behavior and ecodynamics in the period comprised between the end of the Last Glacial Maximum (LGM) and the Holocene.

While there had previously been some preliminary analysis done on the excavated lithic artifacts from these layers at Picareiro, it was largely limited to a basic inventory of the types of lithic artifacts present and the raw materials utilized in their production (Bicho et al 2006). Presently, the only detailed analysis done on the Magdalenian lithic assemblage from Picareiro was performed within the scope of an undergraduate dissertation (Mendonça 2006). Important to note also is that the analysis from these two instances were limited to artifacts recovered from excavations dating before 2010 , so with the continued excavation to present, there was substantially more material that has been recovered and thus requiring analysis.

This thesis provides an in-depth analysis of the lithic materials recovered from the Late Magdalenian occupation Layer F/G from Lapa do Picareiro. The analysis focuses on raw material preference and use, representation of reduction phases, and typologies present. In doing so, this allows for the data from the assemblage to be compared to other regionally contemporaneous sites.

This data generated from this thesis, when looked at in conjunction with the analyzed faunal assemblage, allowed the previously held assumptions about the role of Picareiro during the late Magdalenian to be tested. It also allowed for the observed patterns found in the lithic assemblage to be contextualized within the broader context of the Late Magdalenian in central Iberia. 
This thesis will be organized into seven additional chapters. Chapter II provides an introduction and background into the Upper Paleolithic, ultimately discussing how it is exemplified in the Portuguese archaeological record. From this point, the site of Lapa do Picareiro is introduced and the history and chronology of the site is described. Chapter III is dedicated to the establishment of the climate, paleo-environment, subsistence, and mobility during the Late Pleistocene in Portugal. This chapter helps contextualize the cause and effects of what was going on at Lapa do Picareiro. Chapter IV presents the various analyses that were conducted on the Late Magdalenian assemblage at Lapa do Picareiro in the past. Chapter V presents the methodology for this thesis research conducted on the lithic assemblage. Chapter $\mathrm{VI}$ is a presentation of the data collected from the analysis of the lithic assemblage. Chapter VII presents the conclusions of this work, comparisons of the assemblage to other regionally contemporaneous sites, and future opportunities for further analysis and investigation. 


\section{CHAPTER II:}

\section{BACKGROUND AND HISTORY OF INVESTIGATION}

\section{The Upper Paleolithic}

Western Europe became home to the first Modern Humans roughly $35 \mathrm{ka}$ cal BP, during the Aurignacian phase of the Upper Paleolithic. These peoples inhabited a variety of settings, ranging from caves to open air camps, and subsisted by exploiting an array of resources ranging from locally foraged plants, hunting large and small game animals, and even taking advantage of aquatic resources via the development of fishing practices (Sonneville-Bordes 1963). While their lithic toolkits still contained type artifacts associated with the Middle Paleolithic, such as Mousterian side scrapers, Upper Paleolithic assemblages were identified by the introduction of specialized lithic technologies, such as intense blade technologies and micro-blades, the use and development of various types of bone and antler tools, such as needles, fishing hooks, and projectiles, they wove nets and ropes out of natural fibers to be utilized in hunting endeavors, and they produced works of artistic expression in the form of figurines, cave and rock art paintings, and engravings (Ambrose 2001; Sonneville-Bordes 1963).

Most of the archaeological information from the Magdalenian is drawn from the "classical" or "type" sites in the southwest of France, between the Loire 
River and the Pyrenees mountains (e.g. Le Madeleine) and Spain, primarily from Cantabria (e.g. La Riera Cave) (Straus 1996). Due to the rich depositional history of these regions, the assignment of chronological titles and typologies for most of the Paleolithic originated there (Aurignacian, Magdalenian, Azilian, etc.) (Sonneville-Bordes and Perrot 1954-1956). The Magdalenian, when compared with previous chronological time frames, is most often identified by the exhaustive exploitation of raw material, the miniaturization of the tools produced, the presence of antler and bone harpoons, and an increase in diversity within lithic assemblages, including a multitude of burins, endscrapers, points, and backed blades and bladelets (Straus 1996; Zilhão 1997a; Bicho 2000; Gameiro 2012).

\section{Upper Paleolithic in Portugal}

Interest in the Paleolithic of Estremadura in Portugal can be traced back to the early $19^{\text {th }}$ century investigation conducted by Carlos Ribeiro and Joaquim Filipe Nery Delgado of the Serviços Geológicos (Bicho 1992, 2000; Zilhão 1997a; Pereira 2010; Haws 2003). The primary reason for this investigation was to establish if there was coexistence of extinct Pleistocene animals and prehistoric human populations in Portugal, as had been found in northern France (Haws 2003). As a result of this investigation, there were many archaeological sites identified and excavated, including excavations led by Manuel Heleno in the Rio Maior valley (Zilhão 1997a; Bicho 2000; Haws 2003; Pereira 2010). During this time, George Zbyszewski and Henri Breuil established the classification of the Portuguese Upper Paleolithic in the "classical" chronology utilized in the type 
sites of France (Haws 2003; Pereira 2010). More recently, Anthony E. Marks and João Zilhão developed a project in the late 1990's to ultimately produce a detailed chronology for the Upper Paleolithic of Portuguese Estremadura (Bicho 2000; Marks et al. 1994). Ultimately, the utilization of the "classical" chronology associated with the type sites of France is still utilized today when discussing the Portuguese Upper Paleolithic. The chronology is thus defined as: Aurignacian (33,000-25,000 BP), Gravettian (25,000-22,000 BP), Solutrean (22,000-17,000 BP), and Magdalenian (17,000-10,000 BP) (Haws 2003; Straus 1996; Zilhão 1997a).

\section{Portuguese Estremadura and the Magdalenian Period}

The Portuguese Estremadura encompasses the central coastal portion of Portugal bordered on the north by the Mondego River basin, on the south by the Tejo River basin, on the east by the mountainous Serra da Estrela, and stretching all the way to the Atlantic Ocean on the west (Haws 2003). This region is home to the Serra d'Aire limestone massif that rises to $650 \mathrm{~m}$ above sea level, marked by karstic caves and shrubby vegetative cover; the rest of the region consists of sporadic mountainous rises surrounded by plains and valleys (Haws 2003). The landscape is heavily cultivated with olive, fruit, and eucalyptus trees, resulting in the exposure of open air Paleolithic sites due to deep plowing (Haws 2003). Outside of anthropogenic activities, Estremadura has also been shaped by eustatic and climactic fluctuations along with tectonic and karstic processes (Marks et al. 1994). 
During the Upper Paleolithic, this region possessed many desirable ecological traits for prehistoric humans. Primarily that the region was largely dominated by Mediterranean plant species with some Atlantic species, making it an ideal home of many large and small game species, and it possessed locally available high quality chert sources ( See Matias 2012 for in depth discussion of chert sources; Pereira et al. 2015; Zilhão 1997a, Haws 2003, Marks et al. 1994).

\section{The Magdalenian Lithic Assemblages of Estremadura}

The Magdalenian was once considered to be an identifiable and homogeneous culture across the whole of Europe; however the concept is now utilized more as a chronological definer than as being representative of a cultural group (Zilhão 1997a; Gameiro 2012; Bicho 2000; Bicho and Haws 2012). The Magdalenian in Portugal for example, possesses many temporal, typological, and technological variations when compared with the more traditional core sites of Southwestern France and Northern Spain from the same time frame (Zilhão 1997a; Marks et al. 1994; Bicho 2000; Bicho et al. 2012; Bicho and Haws 2012). Despite these differences being well known in the archeological community, the term Magdalenian is still dominantly utilized in the literature thus, the traditional chronological definers established for the Portuguese Upper Paleolithic by Zbyszewski and Breuil will also still be utilized in this work for continuity.

In Estremadura, there are four sub-phases of the Magdalenian identifiable within the region: the Early Magdalenian dating between 20 and $18 \mathrm{ka}$ cal BP, the Middle Magdalenian dating between 18 and $15 \mathrm{ka}$ cal BP, the Late Magdalenian dating between 15 and $12 \mathrm{ka}$ cal BP, and the Terminal 
Magdalenian dating between 12 and 10 ka cal BP (Zilhão 1997a; Gameiro 2012). Technologically the Magdalenian in Portugal is marked by a lack of bifacial technology and a decrease in overall tool size, while typologically it is marked by an increase in backed bladelets and micropoints, but is mostly comprised of nonretouched flake blanks (Zilhão 1997a; Gameiro 2012; Marks et al. 1996; Bicho 2000; Bicho and Haws 2012; Bicho et al. 2011).

More specifically, the Early and Middle Magdalenian in Portugal can generally be identified by a lower frequency of chert, and a higher frequency of quartz and quartzite (Gameiro 2012; Bicho and Haws 2012). The flakes produced during this time commonly possess unfaceted platforms (with large amounts being cortical), have triangular cross sections, and are randomly shaped; the bladelets most commonly have feathered and converging terminations (but are rarely pointed) and unfaceted platforms (Bicho and Haws 2012). The Late and Terminal Magdalenian can generally be identified by an increase in utilization of chert, and a general decrease in use of quartz and quartzite (Gameiro 2012; Zilhão 1997a; Bicho and Haws 2012). The flakes produced during this time possess unfaceted or faceted platforms (cortical platforms becoming relatively uncommon), have triangular and flat cross sections, and vary in their shapes; bladelets become more common and frequently possess feathered terminations (however hinged and plunging terminations are also common) (Gameiro 2012; Zilhão 1997a; Bicho and Haws 2012). 
Despite the differential fluctuation in representative use during the different stages of the Magdalenian, the utilization of multiple types of raw material is nonetheless very common and consistent throughout this time period in Portugal (Gameiro 2012; Pereira 2010; Zilhão 1997a). Throughout the literature, there are two main theories on the differential utilization of raw materials throughout the Upper Paleolithic, the first being that hunter-gatherers were utilizing "low quality" raw materials to produce expedient technologies conserving the "high quality" raw materials for more intensive reduction sequences (e.g. Zilhão 1997a), the other being that raw material was selected based upon the intended use of the tool (e.g. Bicho 2000; Aubry et al. 2008; Almeida 2000, Pereira et al. 2012; see Chapter III section Raw Material Availability and Pereira 2010 for more in depth discussion).

\section{History and Chronology of the Site}

Lapa do Picareiro is a cave site in Estremadura, located near the town of Covão do Coelho in the Serra d'Aire limestone massif (39³1'48.99" N, 8039'10.68" W). Opening on the western face of the mountain range, the cave overlooks a wide valley that lies roughly $10 \mathrm{~km}$ south of the town of Fatima and $40 \mathrm{~km}$ to the west of the Atlantic coast (Bicho et al. 2000). Sitting at roughly 570 meters above sea level, it represents the highest currently known elevation Upper Paleolithic site in central and southern Portugal (Bicho et al. 2011). Interest in Picareiro can be traced back to the late 1960s, when Antonio Marques and Jorge Andrade performed a trench test of the site. This trench later proved to yield evidence of Iron Age deposits including several human burials 
associated with decorated pottery (Bicho et al. 2000; Haws 2003). The site lay largely disregarded until João Zilhão and members of the Sociedade Torrejana de Espeleologia e Arqueologia (STEA) revisited the site in 1988 and recovered materials suggesting the potential for Upper Paleolithic deposits (Haws 2003; Zilhão 1997a). Scientific investigation of the site did not really occur again until 1994 when, as part of a larger research endeavor, Nuno Bicho tested the site and took samples resulting in the confirmation of the presence of archaeological layers corresponding to the Upper Paleolithic (Bicho et al. 2000; Haws 2003).

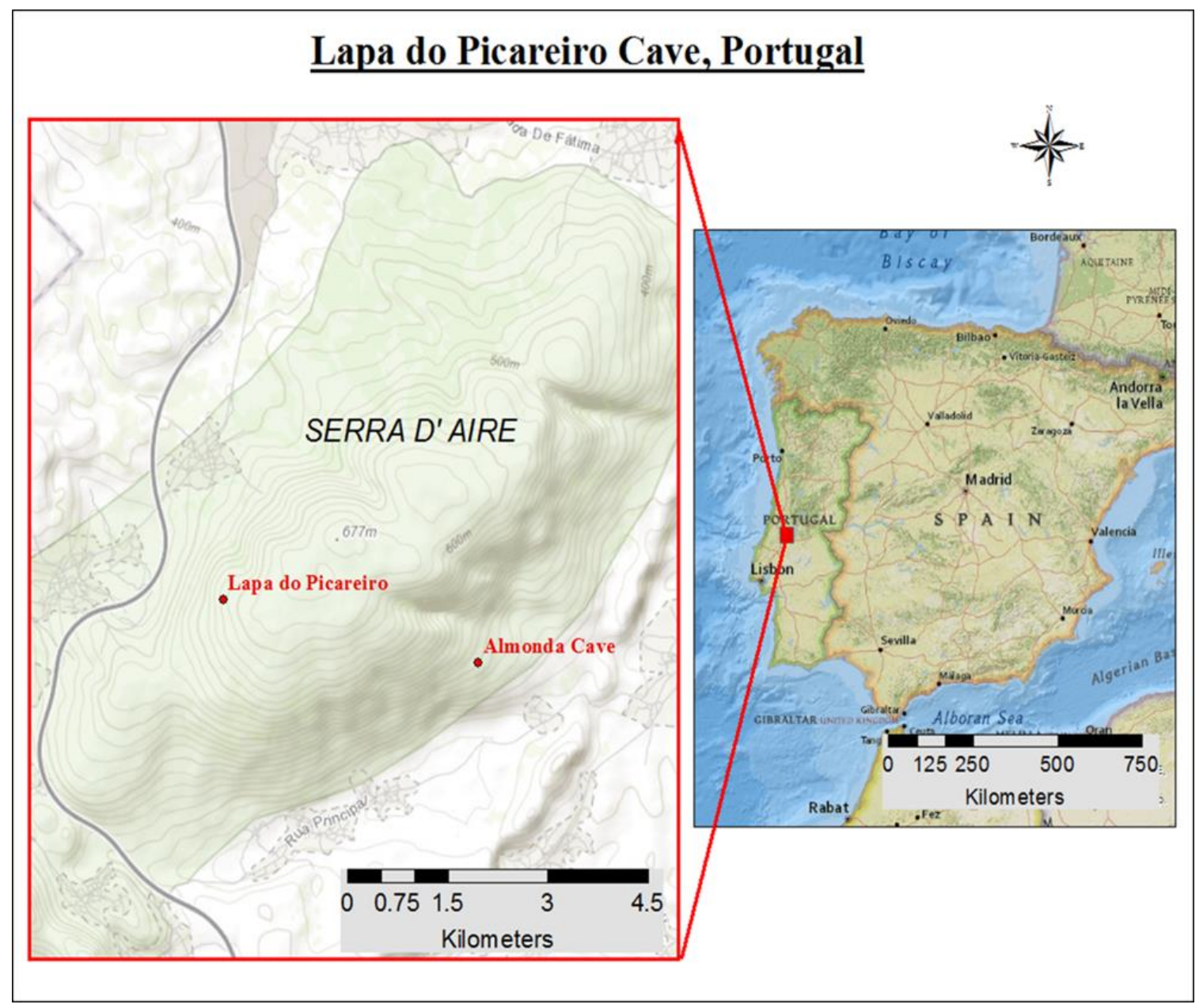

Figure 2.1: Map of the Iberian Peninsula with Lapa do Picareiro identified in the Serra d'Aire mountain range in central Portugal. 


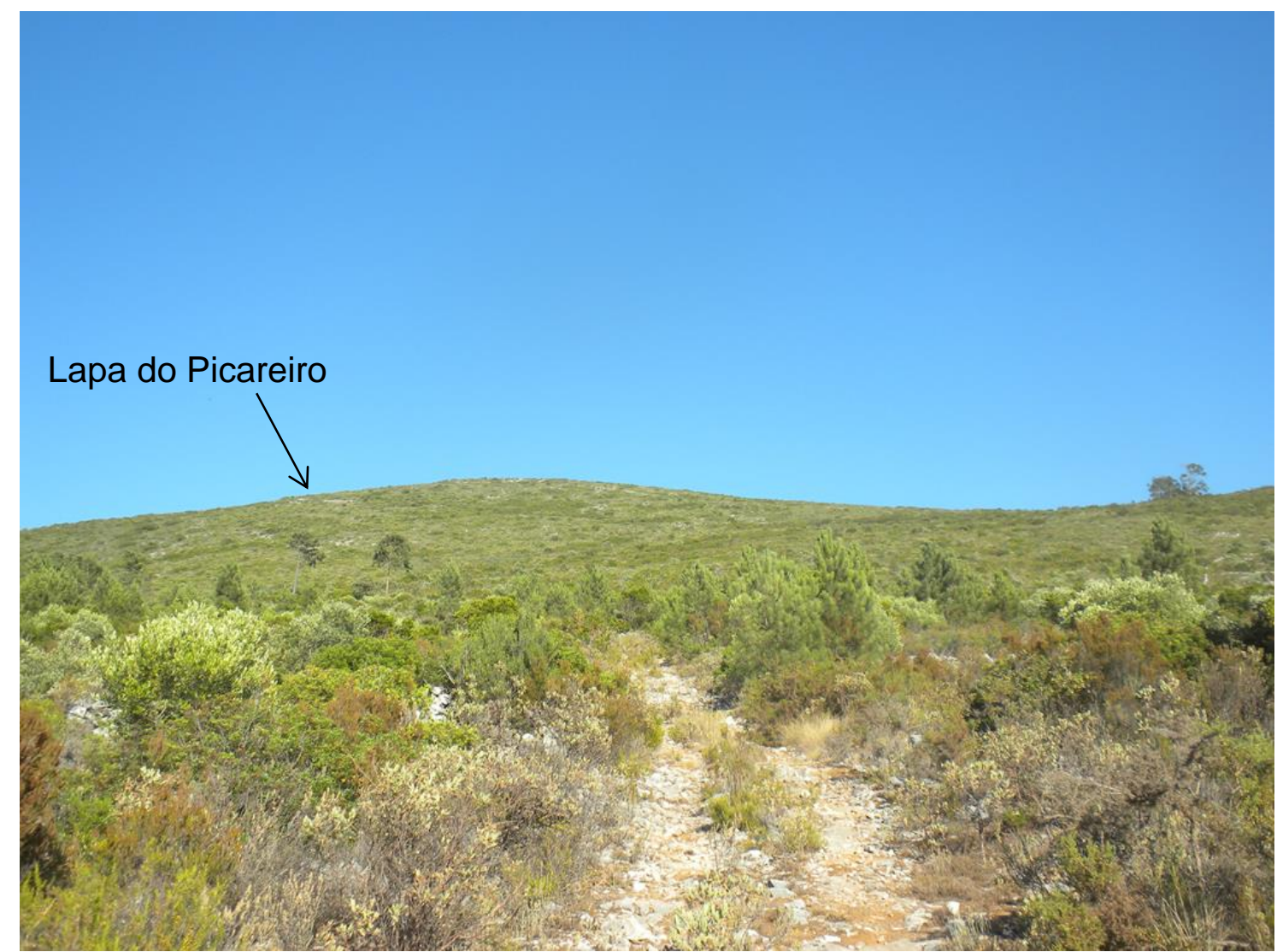

Figure 2.2: Western face of the Serra d' Aire mountain range with locations of Lapa do Picareiro indicated.

In the following year, 1995, Bicho initiated what would become a long term interdisciplinary archaeological excavation of Lapa do Picareiro (Bicho et al. 2000). During the systematic excavation of the site, utilizing $1 \mathrm{~m}^{2}$ units on an alpha-numeric grid, identifiable archaeological and faunal materials were pieceplotted. The removed sediment was then dry screened and/or water screened utilizing $4 \mathrm{~mm}$ and $1 \mathrm{~mm}$ mesh screens to recover any small or missed archaeological and faunal materials (Bicho et al. 2000; Haws 2003). The excavation ultimately revealed the presence of 19 stratigraphic layers labeled AS; Six of those layers (D, E, F, and G) were successfully dated (Layer D: 8,300 \pm 120 BP, Layer E: 10,070-11,500 \pm 120 BP, Layer F: 11,700-12,300 BP, Layer G: 
12,300 BP) (Haws 2003; for current accepted chronological dates see Appendix I). Archaeological excavation of the site resumed in 2005, under the direction of Jonathan Haws. Excavation and analysis of the site continue to the present day.

Currently, Lapa do Picareiro has been excavated to expose over 10 meters of sediment sequence spanning roughly 50,000 years with bedrock and the horizontal limits of the cave yet to be reached. The techniques utilized for excavation have been kept consistent between the two site directors. Both utilized the grid that divides the cave into $1 \mathrm{~m}^{2}$ units and maintained vertical control during the excavations by following the geologic layers present, and subsequently dividing those into $5 \mathrm{~cm}$ thick spits (Bicho et al. 2006). A characteristic that makes Picareiro stand out from many other contemporaneous sites in the region is its continuous depositional sequence. The sediment filling the cave is largely the result of the chemical and physical erosion of the cave itself, resulting in the deposition of clasts of various sizes and quantities relative to the climatic influences of the time (Bicho et al. 2006). The continued excavation has now exposed 40 deposition layers, labeled A through NN. The current excavation, while maintaining the methodology utilized by Bicho to systematically excavate the cave, is working to improve the accuracy of the piece-plotting of archaeological and faunal materials recovered during the excavation. The excavation implemented the use of an electronic total station in 2013 and currently utilizes a Sokkia CX-103 total station. The Enterprise Data Management (EDM) system, designed by Harold H. Dibble and Shannon P. McPherron and available at Oldstoneage.com, is used to organize data 
collection. It was specifically designed for the organization of piece plotted artifacts found at Paleolithic sites.

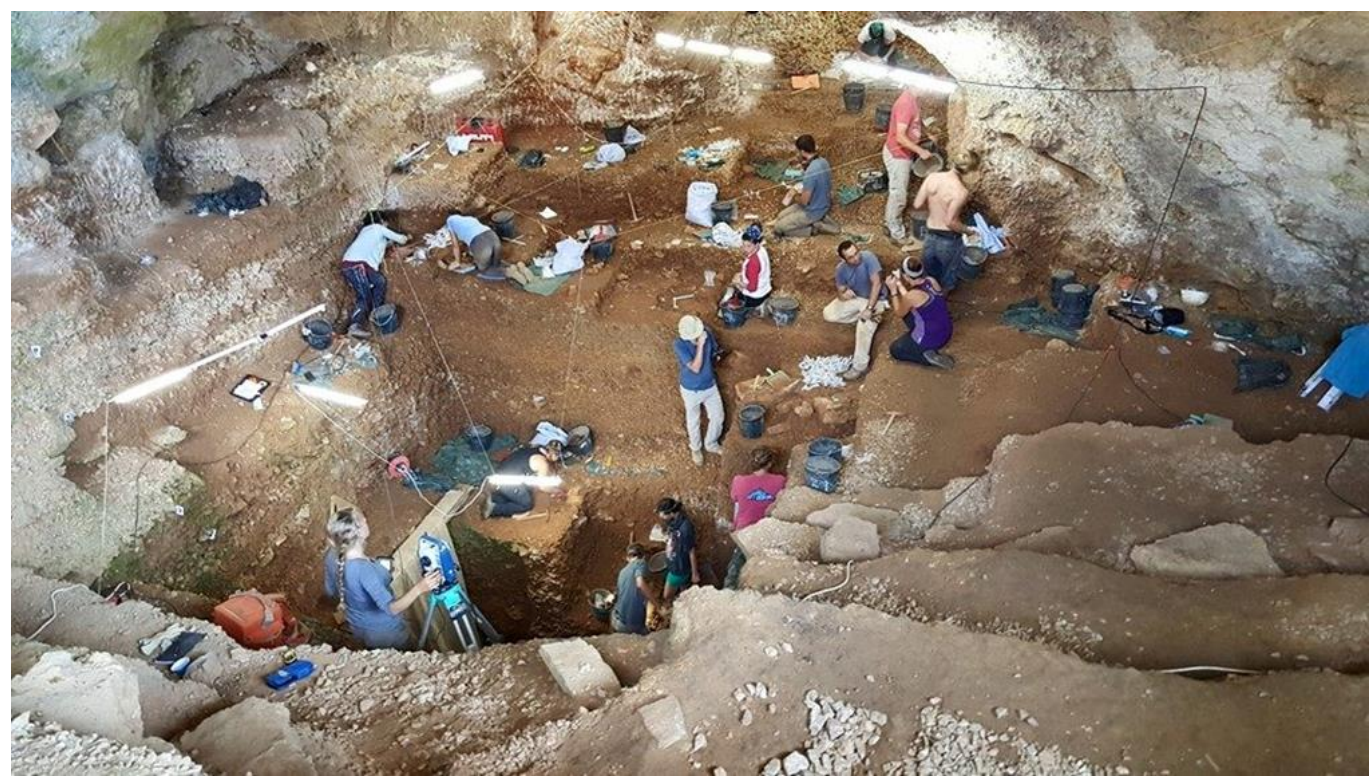

Figure 2.3: 2015 Excavation inside Lapa do Picareiro

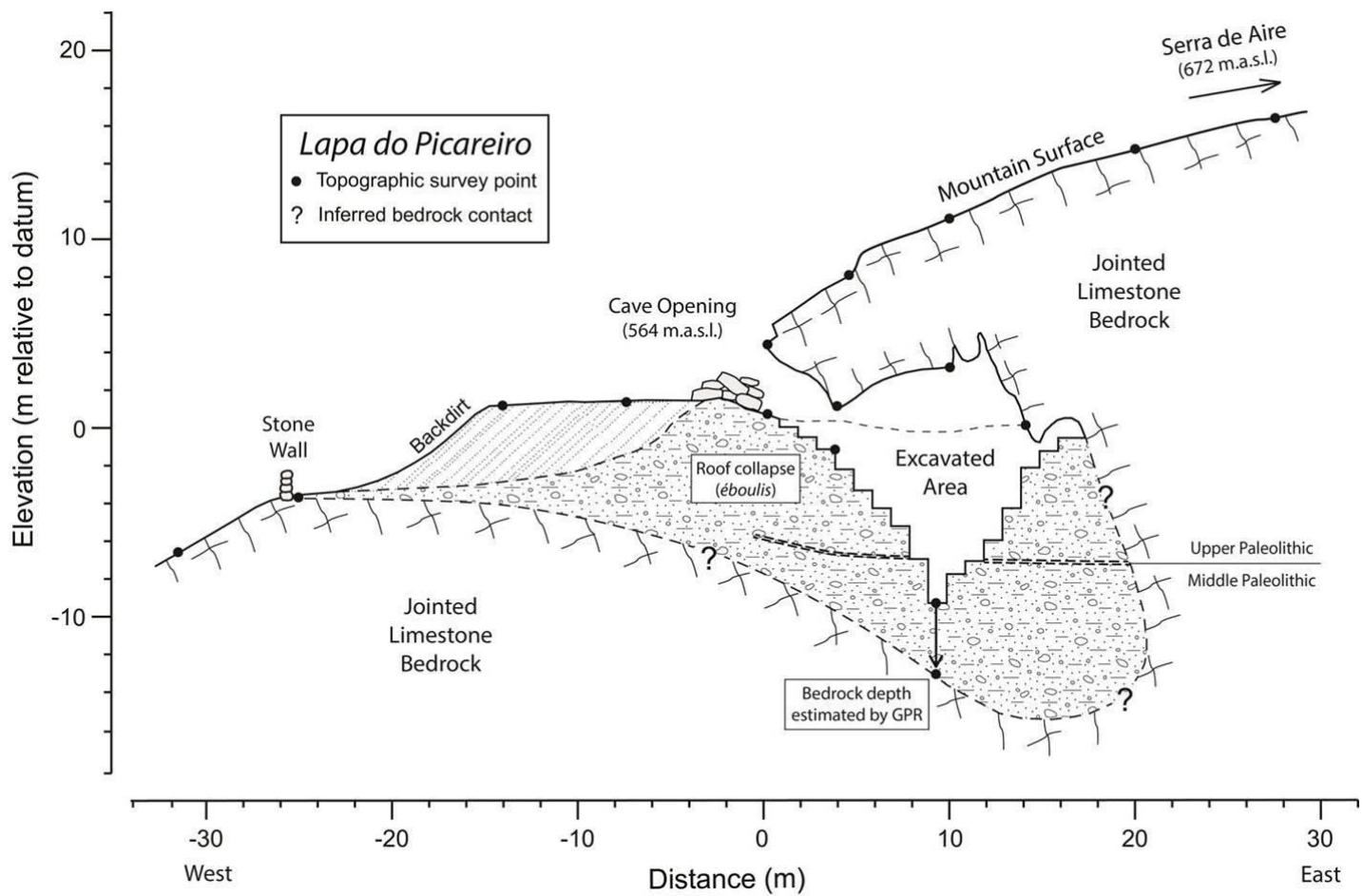

Figure 2.4: Profile of Lapa do Picareiro (Provided by Jonathan Haws 2017) 


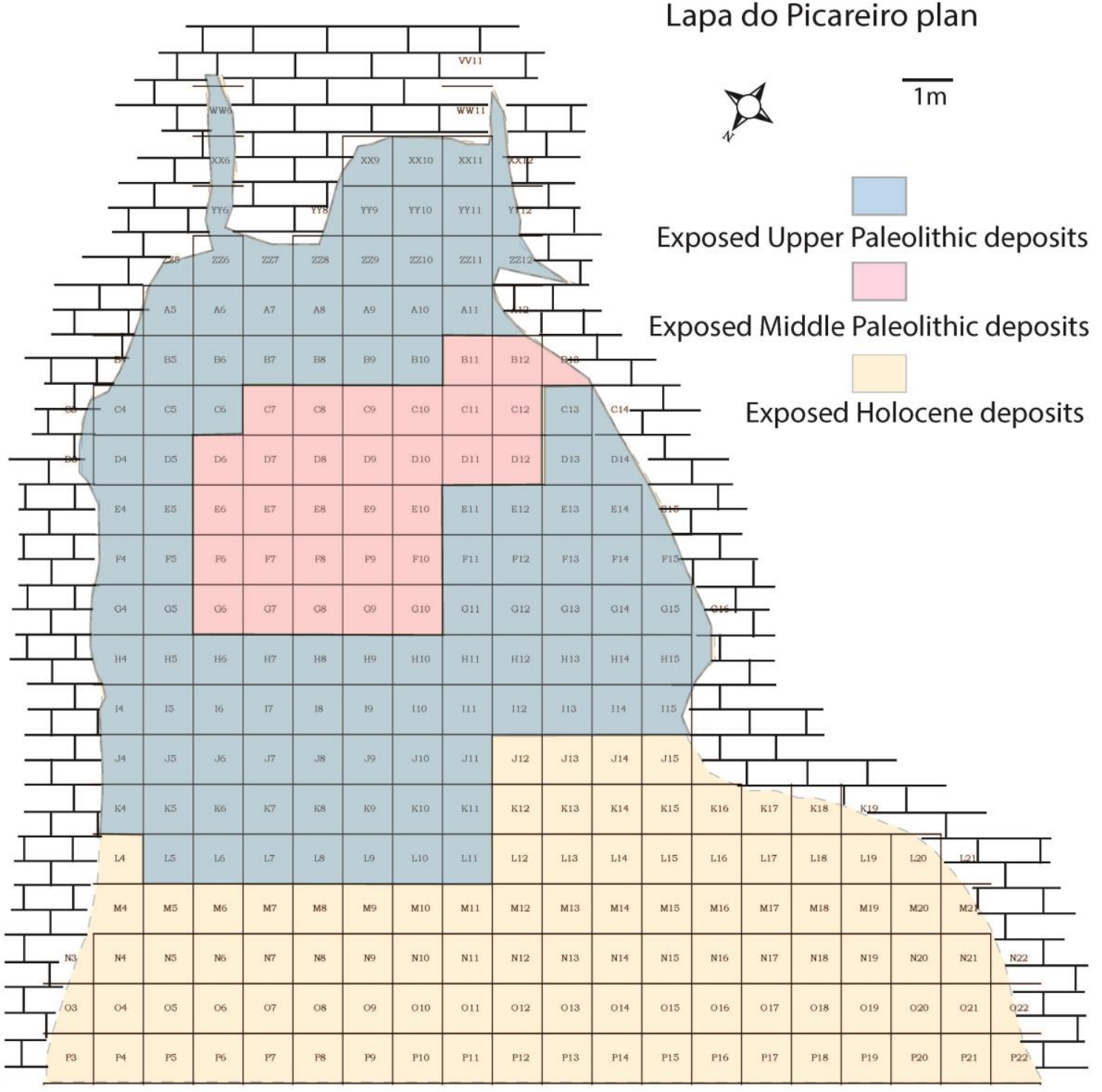

Figure 2.5: Interior plan of the cave with excavated units and their correlating excavated deposits (Provided by Jonathan Haws 2017). 


\section{CHAPTER III:}

\section{CLIMATE, PALEO-ENVIRONMENT, SUBSISTENCE, AND MOBILITY DURING THE LATE PLEISTOCENE IN PORTUGAL}

One major challenge that archaeologists must face when trying to understand past human societies is how their adaptive responses were shaped by changes in climate (Naughton et al. 2015:1). The peoples of the late Pleistocene experienced drastic and abrupt fluctuations in climatic conditions all across Europe, resulting in many adaptive responses that effected their mobility, settlement patterns, subsistence, and technological strategies (Naughton et al. 2015; Haws 2003). While a general typological analysis of an assemblage can provide some basic interpretations about any lithic assemblage, if you don't understand the broader context from whence it came, any meaningful information pertaining to prehistoric human behavior and adaptive responses would be lost (Thacker 1996); Thus, the need for a broad understanding of the external processes and pressures that influenced prehistoric human adaptive capabilities. Possibly the most important of which is the influence of climate and climatic events. The data available for understanding what the climate and environmental conditions were like during the late Pleistocene in Portugal is largely limited to geologic stratigraphy, deep sea cores, charcoal samples, pollen analysis, and faunal analysis (Haws 2003: 103; Naughton et al. 2015). It is through an 
interdisciplinary analysis of this data, and the syntheses of this data regionally (e.g. Zilhão 1997a) that is ultimately conducive to understanding the conditions that elicited varying adaptive responses (Haws 2003).

\section{Climatic events and their impact on the paleo-environment}

During the late Pleistocene, there were two types of climatic events that resulted in significant impacts on Western Europe; namely the Heinrich Events (HEs) and Dansgaard-Oeschger stadials (D-O stadials). D-O stadials are cyclical climatic events that represent abrupt atmospheric changes over Greenland, consisting of oscillations between warm phases (interstadials) and cold phases (stadials); while HEs represent the southward expansion of polar waters from icebergs that broke off the Laurentide Fenno-Scandinavian ice sheet and melted as they moved southward into the North Atlantic (Fletcher and Sánchez Goñi 2008; Sánchez Goñi et al. 2000; NOAA 2008). These events are recorded in marine sediments as continuous layers of coarse grained sediment, referred to as Ice Rafted Detritus (IRT), and high percentages of planktonic foraminifer (Neogloboquadrina pachyderma) in the North Atlantic (Sánchez Goñi et al. 2000;

Sánchez Goñi et al. 2008; NOAA 2008). They also are marked by abrupt cooling of sea surface temperature (SST), decrease salinity of the ocean water, and sharp increase in magnetic susceptibility (Sánchez Goñi et al. 2000:395).

To study these depositional layers, samples (called cores) were removed from the ocean floor by drilling with a hollow tube. This tube, as it bores down, collects the deposited sediment in its original stratigraphic sequence which can then be analyzed with its chronology still intact. Several of these marine cores 
have been retrieved from the Iberian margin and studied in detail; these include MD95-2042, MD95-2040, MD03-2697, MD99-2331, SU81-18 among many others (Moreno et al. 2002; Salgueiro et al. 2014; Sánchez Goñi et al. 1999; Sánchez Goñi et al. 2008; Naughton et al. 2015). There are very few regions in the world that have been cored as extensively as the Iberian margin (Salgueiro et al. 2014: 318). Analysis of these marine cores, in conjunction with other climateproxy data such as the Greenland ice cores, palynological studies, charcoal analysis, and faunal analysis, has allowed for the establishment of a chronology for paleo-climatic conditions in western Iberia during the late Pleistocene (Sánchez Goñi et al. 2000; Moreno et al. 2002; NOAA 2008; See table 1.1). Through the interdisciplinary analysis and comparison of these various climateproxies it has been largely concluded that during D-O cycles and HEs, there were significant changes in terrestrial vegetation and sea surface temperatures within a range of about 150 thousand years as direct results of a climatic event (Sánchez Goñi et al. 2002: 104; Sánchez Goñi and d’Errico 2005). Specifically relevant to the understanding of the adaptive responses employed during the Magdalenian in central Portugal would be to look at more closely the climatic events of HE1, the Bølling-Allerød interstadial, and the Younger Dryas (see table $3.1)$.

HE1/Oldest Dryas occurred 17,000 to 15,000 cal BP and is initially marked by an abrupt SST cooling, roughly $8^{\circ}$ to $10^{\circ}$ Celsius, an increase of planktonic foraminifer, and an increase in deposition of IRD, and a large increase in magnetic susceptibility (Naughton et al. 2015; Salgueiro et al. 2014; Combourieu 
Nebout et al. 2009). During this event, the palynological records indicate that the on the Iberian Peninsula there was a reduction in arboreal pollens and an increase in semi-desert/grassland plants (Combourieu Nebout et al. 2009: 511; Naughton et al. 2015). Despite some warming within the HE1 event, it was largely a dramatically cold climatic event. Reconstructed annual temperature and precipitation indicate extremely cold conditions (Combourieu Nebout et al. 2009: 513).

The Bølling-Allerød insterstadial spans roughly 14,700 to 12,900 cal BP, (Salgueiro et al. 2014). It is characterized by a sudden and substantial increase in SST, and thus a decrease in planktonic foraminifer; this period is characterized as being the closest to current day temperatures out of all the late Pleistocene climatic fluctuations (Naughton et al. 2015). The palynological records indicate a massive expansion of Mediterranean/temperate plant species; however the semidesert/grassland plants were still present but their palynological footprint decreased as the Bølling transitioned into the Allerød period being indicative of a continuous increase in temperature and moisture availability as time progressed (Naughton et al. 2015: 8; Combourieu Nebout et al. 2009: 511). During this time period, the sea level rose to roughly $40 \mathrm{~m}$ below the current sea level resulting in the loss of about $25 \%$ of the available land in central Portugal (Haws 2003: 107).

The Younger Dryas, also referred to as Dryas III, occurred 12,500 to 11,750 cal BP (Combourieu Nebout et al. 2009; Salgueiro et al. 2014). This climatic event was characterized by a relatively significant decrease in SST $\left(2^{\circ}\right.$ to $4^{\circ} \mathrm{C}$ ) resulting in the presence of planktonic foraminifer, but there was no peak in 
IRD indicating that there was no icebergs that made it to the lberian margin of the Atlantic (Naughton et al. 2015:8). According to Combourieu Nebout et al. (2009) this period can be divided into two parts: an initial very dry and cold period followed by a more humid and cold period; this fluctuation could be the result of a shift in the hydrologic cycle among other possibilities (Combourieu Nebout et al. 2009: 514). The palynological record indicates a decrease in Mediterranean/temperate plant species and a major increase in grasses but with only minor increase semi-desert plants, being indicative of an overall cold but moist climate for Iberia (Combourieu Nebout et al. 2009: 511; Naughton et al. 2015). During this period sea level was $60 \mathrm{~m}$ below the present level (Haws 2003:17).

\section{Late Pleistocene mobility and subsistence}

Based on pollen analysis from various marine cores taken off the coast of Iberia changes in vegetation in the Iberian Peninsula coincided with the cycle of D-O stadials and interstadials, presenting evidence for the rapid response of vegetation to the fluctuations in climatic conditions (Sánchez Goñi and d'Errico 2005; Combourieu Nebout et al. 2009). As generally described in the previous section, the cold episodes corresponded to the expansion of semi-desert grassland consisting largely of heather (Calluna and Ericaceae species) and juniper (Juniperus) and the warm episodes corresponding to expansion of Atlantic/Mediterranean forests consisting primarily of pine (Pinus pinaster), birch (Betula pubescens), and evergreen and deciduous oak (Haws 2003: 115; Sánchez Goñi and d’Errico 2005; Combourieu Nebout et al. 2009: 511). 


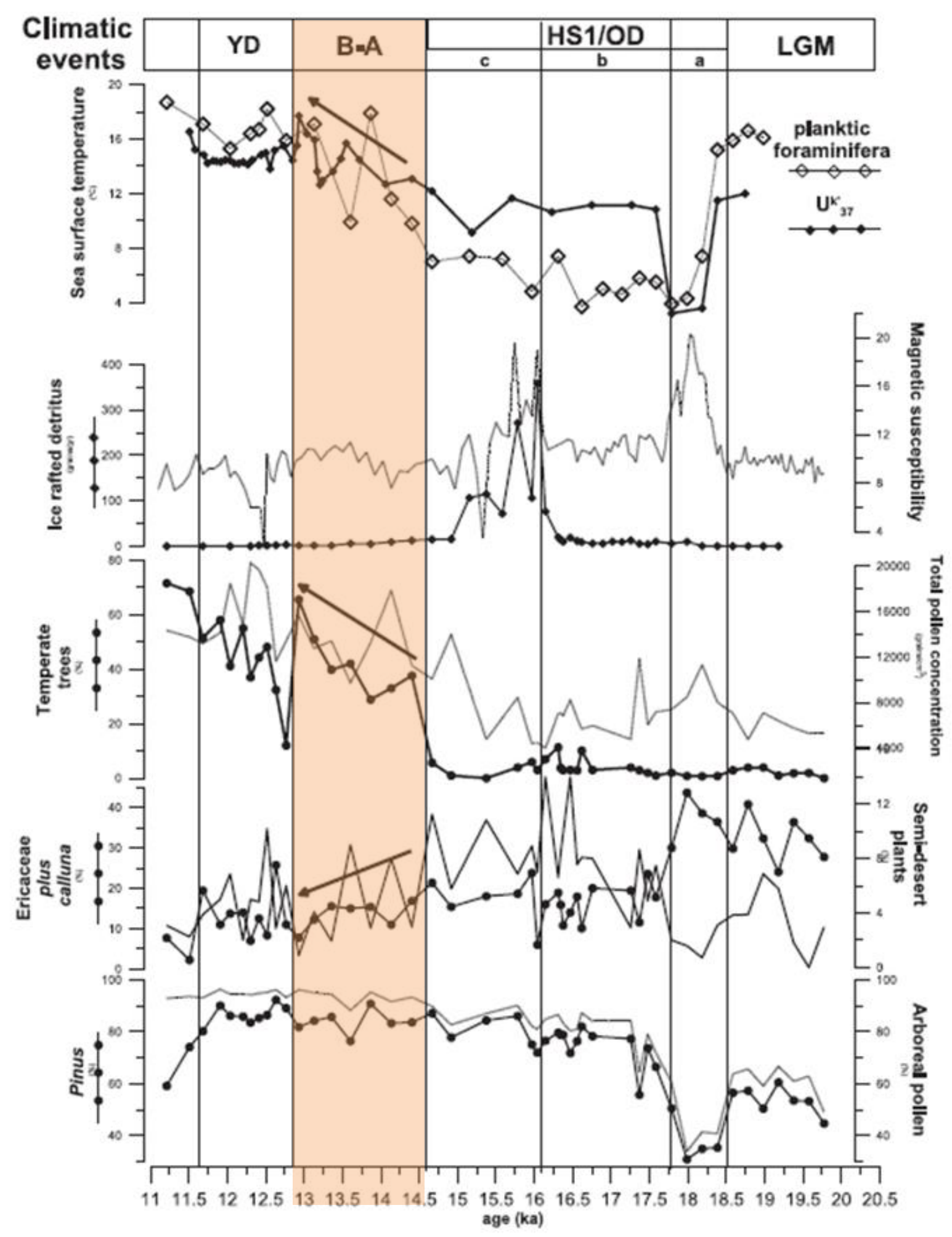

Figure 3.1: Climatic events that occurred during the Late Pleistocene and the resulting signatures they left in both marine and terrestrial cores. The climatic event corresponding to layer F/G of the cave, is highlighted (Adapted from Naughton et al. 2015:7). 
Due to the intensity of the cold conditions that accompanied the HE1/Oldest Dryas, resulting in extremely dry conditions, terrestrial game animals would have been nutritionally stressed and greatly decreased in available numbers. Thus prehistoric populations would have been forced to exploit coastal and marine resources such as shellfish, fish, and marine mammals for protein and fat (Haws 2003: 290-291). The archaeological record shows that during this event there is a major decrease in inland site habitation, some areas representing a complete hiatus (Haws 2012: 7). This shift to reliance on aquatic resources for sustenance would result in prehistoric peoples settling along the coast, but unfortunately if this is the case, with $40 \mathrm{~km}$ of the continental shelf underwater, all evidence of this would be submerged under several meters of water (Haws 2003:107, 291).

When the climate ameliorated, entering into the Bølling-Allerød insterstadial, prehistoric hunter-gatherers found themselves surrounded by a landscape lush with highly productive plants and an increase in available terrestrial game animals. Rabbit (Oryctolagus cuniculus), wild boar (Sus scrofa), and red deer (Cervus elaphus) were among some of the game animals available on the landscape during this period (Haws 2003). This abundance of edible resources, along with the available marine and coastal resources allowed for a more diverse and nutritional diet, resulted in healthier populations and thus population growth (Haws 2003:291). Resuming the dry summer/wet winter cycle, hunter-gatherers would have utilized coastal settlements during the dry summer months and inland cave/open air settlements during the winters (Haws 2003). 
At the very end of the Pleistocene, prehistoric peoples would have experienced the Younger Dryas cooling event. This event resulted in an abrupt climatic deterioration from that of the previous Bølling-Allerød, and again there is a hiatus within the archaeological record (Haws 2012:7). However, at the end of the Younger Dryas climatic event, there was significant amelioration with the landscape largely returning to its pre-Heinrich Event 1 state. These landscapes would thus be inhabited by a variety of herbivores and vegetation would be composted of deciduous oak (Quercus), pine (Pinus pinaster), wild olive (Olea europaea), willow (Salix), and ash (Fraxinus angustifolia) ( Haws 2003; Bicho and Haws 2012). Faunal remains indicate that rabbit (Oryctolagus cuniculus), red deer (Cervus elaphus), and horse (Equus caballus) were still present on the landscape with a major decrease in ibex (Capra pyrenaica) and a complete disappearance of chamois (Rupicapra rupicapra) (Bicho et al 2015)(See Table 3.1). This climatic event would have initially resulted in more reliance on coastal settlements much like during the HE1 climatic event, but as the climate ameliorated there would have been a shift back to seasonal mobility as was the case during the Bølling-Allerød. 
NISP of fauna from Magdalenian levels in Picareiro

\begin{tabular}{|c|c|c|c|c|c|c|c|c|c|c|}
\hline Taxon & D & $\mathbf{E}$ & F/G & I & J & $\mathbf{K}$ & $\mathbf{L}$ & $\mathbf{M}$ & $\mathbf{N}$ & 0 \\
\hline \multicolumn{11}{|l|}{ Mammals } \\
\hline Cervus elaphus & 9 & 107 & 440 & 12 & 51 & 14 & 10 & 1 & 21 & 12 \\
\hline \multicolumn{11}{|l|}{ Capreolus capreolus } \\
\hline Cervidae & & 71 & 3 & & 2 & & & & 1 & 2 \\
\hline Capraibex/pyrenaica & & & 4 & & 4 & & 3 & & 3 & 5 \\
\hline Rupicapra rupicapra & & 1 & 1 & & & & 1 & 1 & & \\
\hline Capridae & & & & & 1 & & & & & \\
\hline Bos primigenius & & 8 & 1 & 1 & 1 & & & & & \\
\hline Sus scrofa & & 26 & 139 & 5 & 23 & 1 & 1 & & & \\
\hline Medium ungulate & 16 & 314 & 1,155 & 35 & 158 & 40 & 51 & 4 & 157 & 53 \\
\hline Equus caballus & & & & & & 1 & & & 1 & \\
\hline & & & & & & & & & & \\
\hline Lynx pardinus & & & & & 2 & & & & 1 & 4 \\
\hline \multicolumn{11}{|l|}{ Felis sylvestris } \\
\hline Vulpes vulpes & & & 1 & 1 & 2 & & & & & \\
\hline Oryctolagus cuniculus & 17 & 220 & 17,209 & 353 & 1,313 & 134 & 106 & 2 & 122 & 171 \\
\hline Lepus granatensis & & 1 & 1 & & 1 & & & & & \\
\hline & & & & & & & & & & \\
\hline Erinaceus europeus & & & 5 & & 1 & & & & & \\
\hline
\end{tabular}

Table 3.1: Number of Individual Specimens (NIS) for the Late Pleistocene layers of Lapa do Picareiro (Haws n.d.). Layer F/G correlates to the Bølling-Allerød climactic event.

$\underline{\text { Technological Adaptation and Raw Material Availability }}$

Climatic shifts impacted prehistoric hunter-gatherers in their mobility, subsistence, and settlement patters, however it is not as commonly discussed as to how the effects of climatic events could have influenced raw material availability or stone tool technology (Pereira and Benedetti 2013:20). Foraging Theory suggests hunter gatherers' choices of technological strategies are often determined by the nature of resources available on the landscape (Bousman 1993). When trying to understand the choices made by hunter-gatherer populations, there are two factors that must first be considered: risk and stress.

Risk being the probability of economic loss, where different levels of risk relate to the structure of resources and the predictability of their availability (Bousman 1993). The concept of stress as used here is not only relating to 
physical stress, but to the scarcity of resources. For example, during periods of environmental stability in a warm/humid climate with ample access to resources, risk and stress are both relatively low. During periods of full glaciation where climate is cold and arid, both stress (lack of access to ample resources) and risk (the higher probability of failure) are relatively high.

Raw materials necessary for lithic tool production can also be classified in two ways: constant, meaning available in the same place year round, or contingent, referring to seasonal availability (Bousman 1993, Pereira and Benedetti 2013). This correlation between raw material and its availability are related to decisions pertaining to subsistence and tool production strategies, thus bringing us back to Foraging Theory (Pereira and Benedetti 2013).

"All technical systems result from a design process... the designer selects from the available alternatives to create a solution to an identified problem" (Bleed 1986: 738). Thus, as stated in Foraging Theory, tool production is a result of trying to solve a problem, it is the factors surrounding that problem that shape the toolmaker's choices. As Bleed (1986) describes, a tool should be effective, efficient, and available regardless of the production strategy employed. Meaning that it should be able to do the job it is designed for, do it with minimal 'cost' (in terms of material, production time, etc.), and that it should be largely available to do its job (not requiring ample amounts of continuous maintenance).

Technological production strategies can be divided into three main categories: opportunistic, maintainable, and reliable (Bousman 1993). Opportunistic technological strategies are considered an unplanned technological 
response to an unanticipated need (Bousman 1993). The other two tool production strategies are a bit more complex. Maintainable tools are typically light and easily transportable, capable of quickly being repaired or sharpened, made for utility not specificity, and can be repurposed into another tool when broken (Bousman 1993, Pereira and Benedetti 2013). Reliable tools on the other hand are typically larger and more robust, require long maintenance periods, and designed for a specific task requiring subsequent tools for other tasks (Pereira and Benedetti 2013). While these are all technological production strategies geared at effectiveness, efficiency, and availability, the decisions for the selection of one strategy over another is related directly to how the tool is intended to be utilized (Pereira et al. 2012a; Pereira et al. 2012b; Bicho 2000; Pereira 2010; Gameiro 2012; Aubry and Igreja 2013; Binford 1979). Opportunistic tools seem to correspond to domestic activities, whereas maintainable tools seem to correspond with hunting implements (Pereira and Benedetti 2013; Pereira et al. 2012a; Aubry et al. 2008; Pereira 2010; Zilhão 1997a). In order to understand technological production strategies, it is also important to understand the natural distribution of raw materials on the landscape.

\section{Raw Material Availability}

Pereira and Benedetti (2013) indicate that there are three major geologic regions within the Iberian Peninsula: "chert-poor regions dominated by siliceous Paleozoic rocks, chert-rich regions dominated by limestone, and large sedimentary basins." With the geography of the land the way it was, water played a crucial role in the region when it came to the erosion, movement, and 
deposition of raw materials across the landscape. Due to the mountainous nature of central Portugal, this allowed for a variety of hydrologic settings to exist, ultimately contributing to the fluvial transport of large quantities of raw material (Pereira and Benedetti 2013). Most of the headwaters of the major rivers are located in Central and Eastern Iberia and in their travels to the Atlantic margin, they cross through chert-rich areas before entering chert-poor ones; Thus resulting in large quantities of chert nodules along with other materials good for tool production, such as quartzite, quartz, and greywacke, to be transported across the landscape (Pereira and Benedetti 2013).

The climatic events (described in the previous section) had an impact on the contingency of raw material availability to a certain extent. During the severe cold phases of the Upper Paleolithic, the region would face extreme aridity and thus poor steam flow, resulting in a lack of karst erosion and thus a lack of sediment. Increased aridity also resulted in the carrying capacity of the stream to greatly diminish (Pereira and Benedetti 2013). During warm/humid phases, it would be quite the opposite. There would be an increased stream flow, resulting in increased karst erosion, higher carrying capacity of course sediment, and thus a result of a high yield of raw materials in fluvial deposits (Pereira and Benedetti 2013). This fluvial distribution of raw materials across the landscape is due largely to the Tagus River eroding the massive quartzite crests from the Vila Velha do Ródão region since the Miocene (Pereira 2010).

The main conclusion from the reviewed climatic record is that fluctuations in climate were key drivers of changes in prehistoric hunter-gatherer 
adaptive strategies. Climate changes would have profoundly influenced huntergatherer decision making processes, not only with their subsistence and settlement patterns but also in their technological strategies; thus bringing us back to the concept of Foraging Theory. One of the goals of this thesis is to contextualize the observed patterns found in the late Magdalenian lithic assemblage from layers F/G at Lapa do Picareiro. In doing this, it will also require an understanding of the pressures and processes acting on the hunter-gatherers of the time and the choices, or adaptive responses, they employed to persist through them. 


\section{CHAPTER IV:}

\section{PREVIOUS ANALYSIS OF LITHIC MATERIALS FROM LAPA DO PICAREIRO}

\section{Work by Nuno Bicho}

The preliminary analysis of the lithic materials done by Bicho et al. (2006) revealed interesting evidence alluding to raw material use and reduction strategy that could ultimately provide insight into the site's function and technological organization during this time. The 2006 publication presented a basic analysis and inventory of the lithic materials that had been recovered from layer $F / G$ up to that point. The assemblage consisted of 1,954 lithic materials and was comprised primarily of the four major raw material sources, presented here as number of artifacts and respective percentage: chert $(1,349=69.04 \%)$, quartz $(353=$ $18.07 \%)$, and quartzite $(246=12.59 \%)$ (Bicho et al 2006). The assemblage was then inventoried based on 10 categories: fragments (chunks), chips, complete flakes, flake fragments, complete blade and bladelets, fragments of blades and bladelets, burin spalls, crests and tablets (preparation and maintenance products), cores, and retouched tools (Bicho et al. 2006). From this analysis, Bicho et al. called attention to several interesting trends present within this collection. These trends include the high frequency of chert materials within the assemblage. This, as mentioned in the previous section, is a common trend in Late Magdalenian lithic assemblages in the Estremadura region of Portugal, 
however it is interesting that trend holds true considering the location of Picareiro. The site's location emphasizes the high procurement cost of this specific raw material; its acquisition and transportation to the site would have required a large commitment of time and energy.

The next trend observed in the analysis is the issue of cores, or rather the near lack thereof. Cores are significantly under represented within the inventoried assemblage (of any raw material type), making up less than $1 \%$ of the analyzed materials (Bicho et al. 2006). The cores present are stated to be "of small dimensions with the flaking surface less than $2 \mathrm{~cm}$ long", to this end of the lithic materials analyzed, they proved largely void of core preparation and maintenance products (with only 8 being identified) and cortical flakes, complete or partial, are rare (Bicho et al. 2006). This, as stated by Bicho et al., indicates that the cores were being brought to the site nearly exhausted but already prepared for flake blank production. Bicho et al. (2006) argue that the representation of chips may make sense of the low representation of cores. Chips, defined as measuring less than $4 \mathrm{~mm}$, represent an exceptionally large portion of the assemblage, making up $77 \%$ of the analyzed materials (Bicho et al. 2006). This quantity and size of the chips is indicated to be typically representative of tool sharpening and retouch than from tool production and core preparation (Bicho et al. 2006).

To gain a further understanding of what the 2006 assemblage represented, Bicho et al. then looked further at the category of retouched tools. This category, which represents 121 artifacts, was further divided into 8 basic 
tool classes: burins, endscrapers, truncations, retouched flakes, notches and denticulates, backed bladelets, microlithic points, and other miscellaneous retouched tools (Bicho et al. 2006). Of specific interest was the high number of weaponry tips (backed bladelets and microlithic points) representing over $40 \%$ of the retouched tool assemblage (Bicho et al. 2006). Of even greater significance was that all but one of these weaponry tips were broken with evidence of impact fractures (Bicho et al. 2006). This type of breakage, the researchers believe, was more the result of use during hunting than of post depositional damage (Bicho et al 2006: 497). It is with all of this data and its respective interpretations that Bicho et al conclude that the lithic assemblage at Picareiro was representative of a hunting and carcass processing site.

\section{Work by Telmo Pereira}

Pereira (2010) performed an analysis on the quartzite found at many Upper Paleolithic sites in Southwestern Iberia with the ultimate goal of understanding how quartzite was utilized during this time period. He looked at multiple sites across Estremadura, Alentejo, and the Algarve, including Lapa do Picareiro. Pereira's (2010) analysis of the quartzite lithic materials also included identification of any potential refits from layers $D, E, F$, and $G$ from Lapa do Picareiro. Due to the focus of this thesis, only his results from layers $F$ and $G$ will be presented here.

Pereira (2010) found the quartzite in layer $F$ to be dominantly represented by quartzite of very fine texture, with a low refitting rate (only $3 \%$ ). The ratio of flakes (proximal and complete)/cores is $8.25 / 1$ and $7 / 1$ (Pereira 2010). The 
quartzite cores are identified as having little to no preparation before use, and some of these display extensive exploitation (Pereira 2010). The inventory of tools found in the quartzite of layer F (2010:93) includes: Hammerstones (1), anvil (1), carinated endscraper (1), nucleiform endscraper (1), denticulates (2), notch (1), double convex right scraper (1), simple concave scraper (1), right single scraper (1), and Vale Comprido point (1). Pereira (2010) determines that had the assemblage been based on these quartzite lithic artifacts alone, they could not be definitively attributed to the Upper Paleolithic (92).

Layer $\mathrm{G}$ is again dominated by quartzite of very fine texture, with a small percentage of the assemblage being of fine texture (Pereira 2010:93). The ratio of flakes (proximal and complete)/cores is $38 / 1$ and $23 / 1$ (Pereira 2010). The only core recovered was exploited centripetally. The inventory of tools found in the quartzite of layer $G$ (2010:94) includes: right single scraper (1), denticulate (1), and a convex single scraper (1). Pereira (2010) determined that had the assemblage been based on these quartzite lithic artifacts alone, they could not be definitively attributed to the Upper Paleolithic.

These data provided valuable insight into the value quartzite had for hunter-gatherer populations during the late Magdalenian. The raw material was widely available across the landscape and was of good fine grained quality. Hunter-gatherers developed unique strategies for its exploitation transport across the landscape, and in its intended use (Pereira 2010). While many studies focus primarily on the chert lithic artifacts, this study allows for a holistic perspective on the role of raw materials within lithic assemblages. 


\section{Work by Carolina Mendonça}

The chronologic sequence at Picareiro indicates that the depositional layers correlating to the Magdalenian spans layers $\mathrm{N}$ through $\mathrm{E}$, with the subphase of the Early Magdalenian occupation being represented in levels $\mathrm{N}-\mathrm{K}$ and the sub-phase of the Late Magdalenian being represented by levels G-E. Level J has dates that are considered too young and therefore could be Middle or Late Magdalenian (Mendonça 2011). Level E dating between 11,980 and 13,119 cal $\mathrm{BP}$, which also corresponds to the Late Magdalenian, was presented in an aggregate analysis done by Carolina Mendonça (2011). In her analysis, she found that quantitatively the assemblage is primarily chips from tool retouch and largely lacks the debitage that would indicate that there was a complete reduction sequence present at the site, thus cores must have been initially worked before being brought to Picareiro speaking to the transportation choices of the prehistoric peoples (Mendonça 2011). Retouched tools represented only $2 \%$ of the analyzed lithic assemblage, and that in conjunction with the lack of complete reduction sequence, low representation of cores, and the faunal data recovered from the cave were seen to be indicative of the site being utilized for hunting activities (Mendonça 2011). From the analyzed assemblage it was also noted in the analysis that the tools produced from quartz and quartzite were done so in an expedient manner, whereas tools produced from chert were done more conservatively. While Layer E is not the primary focus of this thesis' analysis, it is important to understand what is going on in the other layers dating to the Magdalenian to determine if there are any diachronic similarities. 


\section{CHAPTER V:}

\section{METHODOLOGY}

The analysis of the assemblage took place over two separate trips to the University of Algarve in Faro, Portugal. The first trip took place in December 2015. The primary goal of this trip was to acquaint myself with the assemblage and establish a preliminary inventory. The second trip took place in June 2016 and produced comprehensive technological, morphological, and typological information. The analysis was conducted utilizing common Western European lithic technological concepts (e.g. Inizan et al. 1999). The assemblage, totaling 3,280 artifacts, was initially divided into general morphological artifact categories. These categories are the most common categories utilized when discussing the Portuguese Upper Paleolithic (Zilhão 1997a; Bicho 2000; Gameiro 2012; Pereira 2010). These categories were used to maintain consistency and comparability with the region so that the analysis done on this assemblage could be utilized in future comparative analyses for other regionally contemporaneous assemblages.

For this analysis, only complete artifacts and fragments possessing an intact platform were subjected to further study beyond their initial general categorization, as is consistent practice among other researchers such as Zilhão (1997a, 1997b), Bicho (2000), and Gameiro (2012). 
Due to the large amount of chips (see definition below) recovered, their high percentage distorts the representation of the other artifacts within the assemblage. Consequently, in order to gain a better understanding of what is present in the assemblage, two methodological decisions were made:

1.) Weight for chips were not taken

2.) Calculations combining effective and relative quantities of artifacts were based upon the total assemblage minus chips.

\section{TECHNOLOGICAL ANALYTIC PROCEDURE}

\section{General Analysis}

All artifacts were classified by raw material and weight in grams. Exception was weight for chips as they are so light that it was not possible to make this measure with certain accuracy. All artifacts were measured in millimeters, except in the case of fragments where the dimension where the fracture occurred was not taken; for example proximal, mesial, and distal blanks where width and thickness were measured, but not length since this is the dimension where the fracture occurred.

\section{TECHNOLOGICAL DEFINITIONS}

Nodule, cobble, and pebble: nodules of raw material that are unused, meaning that they have no presence of stippling or removals.

Core: chunk of raw material that has identifiable flake scars due to its use as a source of flake blanks. Cores also possess identifiable platforms.

Cores were analyzed as so:

- Length: taken on the morphological axis; 
- Width: perpendicular to the maximum length at midpoint;

- Thickness: the cross section where length and width intersect;

- Core Type: chopper, bipolar, chipped stone, multidirectional, prismatic, tested pebble/nodule, core fragment.

- Platform Type: cortical, faceted, flat, bipolar, or indeterminate (if there was no discernable platform).

- Cortex: present or absent. It was then documented in a representative percentage: None, less than $25 \%, 26 \%-50 \%$, 51\%-75\%, 76\%-99\%, Completely Cortical.

- Dominant Flake Scar Pattern: unidirectional, bi-directional, multi-directional, or convergent.

- Dominant Scar Type: elongated, expanding, or intermediate. Blanks: These include flakes, blades, and bladelets

- Flake: a piece of a core that has been removed and possesses a platform and complete termination. The term flake is not indicative of a specific shape or size, but merely a term used to describe a removed piece of raw material that can be used as a tool with or without being retouched.

- Flake fragment: classified as proximal, mesial, or distal. Proximal fragments lack an intact termination, but possess an intact platform and/or bulb of percussion. Distal fragments lack an intact platform, 
but possess and intact termination. Mesial fragments lack both an intact platform and an intact termination.

- Blade: flake with parallel edges whose length is equal or more to twice its width but larger than $12 \mathrm{~mm}$ wide and/or $50 \mathrm{~mm}$ long.

- Bladelet: smaller version of a blade with its length being at least twice its width, but smaller than $12 \mathrm{~mm}$ wide and/or $50 \mathrm{~mm}$ long.

- Blade/bladelet fragments: classified as proximal, mesial, or distal. Proximal fragments lack an intact termination, but possess an intact platform and/or bulb of percussion. Distal fragments lack an intact platform, but possess and intact termination. Mesial fragments lack both an intact platform and an intact termination.

Blanks were analyzed as so:

- Length: taken according to the technological axis;

- Width: taken perpendicular to length at midpoint

- Thickness: the cross section where length and width intersect.

- Platform type: plain, faceted, indeterminate, cortical, or pointed.

- Platform width

- Platform thickness

- Blank shape: circular, semi-circular, rectangular, dejete, rectangular, expanding, convergent

- Blank profile: flat, curved, twisted 
- Transversal cross section: triangular, trapezoidal, flat.

- Dominant flake scar pattern: unidirectional, bi-directional, multi-directional, convergent, or cortical.

- Blank termination: feather, step, hinge, or plunge.

- Cortex: present or absent. It was then documented in a representative percentage: None, less than $25 \%, 26 \%-50 \%$, 51\%-75\%, 76\%-99\%, Completely Cortical.

- Retouch: presence or absence; it was then documented in a relative percentage: none, less than $25 \%, 26 \%-50 \%, 51 \%$ $75 \%, 76 \%-99 \%$, completely retouched.

- Typology: see typological section for various types.

\section{Debris/Possible blanks}

- Burin spalls: reminiscent of bladelets however they possess a thick, often triangular, cross section. This is a result of the production strategy utilized to produce them, the burin blow reduction technique, as opposed to prismatic core reduction which produces blades and bladelets. These were analyzed following the blank criteria (see above).

- Chips: smaller than $1 \mathrm{~cm}^{2}$ and not possessing the previously defined traits of proximal or distal blade/bladelet fragments. While the chips in this assemblage were not analyzed beyond counting their presence within each raw material group, they are 
important indicators of the reliability of the integrity of the assemblage (Zilhão 1997).

- Preparatory and maintenance products: any flake produced as a means to prepare a core for blank production or to remove flaws on a core so that it can be further utilized for blank production. These were analyzed following the blank criteria (listed above).

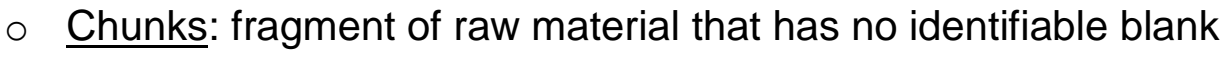
removals or presence of retouch.

- Firecrack: fragment of raw material that has no identifiable blank removals or presence of retouch but possesses the characteristics of being heat treated.

TYPOLOGICAL DEFINITIONS

The identification and defining of the specific typologies was done utilizing Sonneville-Bordes and Perrot (1954-1956) adapted by Zilhão 1997. Definitions and interpretation were also developed through the utilization and adaptation of Andrefsky 2005, Inizan et al 1999, and Bicho 2000.

Domestic Utensils:

- Notch: tools that possess a delineated edge with a sharp concave indentation, sometimes $\mathrm{v}$-shaped, with a small curvature radius that is created by various forms of retouch (Inizan et al 1999: 147).

- Denticulate: possesses at least one delineated edge that displays multiple sharp, concave indentations, sometimes v-shaped, with a 
small curvature radius, in succession of one another (Inizan et al 1999: 138).

- Side scraper: possess at least one steeply retouched lateral edge. Typological differences are attributed to the shape and position of the retouch.

- Thin endscrapers: possess at least one retouched edge, typically along their distal end, and the retouch would be acute.

- Perforator: a type of delineation that refer to a projection outlined by two adjacent notches (Inizan et al 1999: 156).

Hunting Utensils:

- Backed bladelets: bladelets that possess steep retouch along at least one lateral edge. Typological differences are based upon subtle variation in retouch.

Functionally Ambiguous Utensils:

- Composite tools: possess at least two morphologically distinct retouched edges resulting in at least two distinct tool types on the artifact. They typically consist of a pairing of scrapers, burins, perforators, and/or truncations.

- Truncation: possess a line of continuous abrupt retouch along either the proximal, distal, or lateral edge of a blank. Typological differences are based upon the shape and position of the retouch.

○ Burins: a French term that means engraving tool; typologically distinguished based on their overall shape, number and orientation 
of burin spall scars. These scars are at least $5 \mathrm{~mm}$ long and aligned more or less parallel to the long axis of the tool and are the result of the burin blow technique. While the burin itself can be used as a tool, they can also be categorized as cores for bladelet blank production.

\section{Bladelet Cores:}

- Thick endscrapers: possess at least one retouched edge, typically along their distal end. These endscrapers have steeply convergent retouch with laminar flake scars. They can be carinated. 


\section{CHAPTER VI:}

\section{NEW DATA ON LITHIC TECHNOLOGICAL ORGANIZATION AT LAPA DO PICAREIRO}

The primary focus of this thesis project is the Late Magdalenian layers of F/G (Figure 6.1). Excavation of this layer began in 1994 and was completed for the current excavated units within the cave in 2016. Thus, over the course of roughly 22 years, 8,205 artifacts have been piece plotted, recovered, analyzed, and curated all from Layer F/G.

In the case of this assemblage, the site's integrity is $63.9 \%$ (See Appendix II for equation). This is indicative of the integrity of four things:

1.) Human behavior at the cave encompassed in situ knapping;

2.) Site formation processes allowed the preservation of the smallest implements;

3.) The excavation was careful and recovery methods allowed for the collection of these small implements.

Thus, the layer $F / G$ lithic assemblage is reliable for an accurate interpretation of the technological and typological patterns, and more importantly, of the human behavior carried out at the cave. The presentation of the summary of the analysis of this assemblage will be broken up into four sections: raw 
material use, reduction sequence, productivity by raw material, and retouched tools.

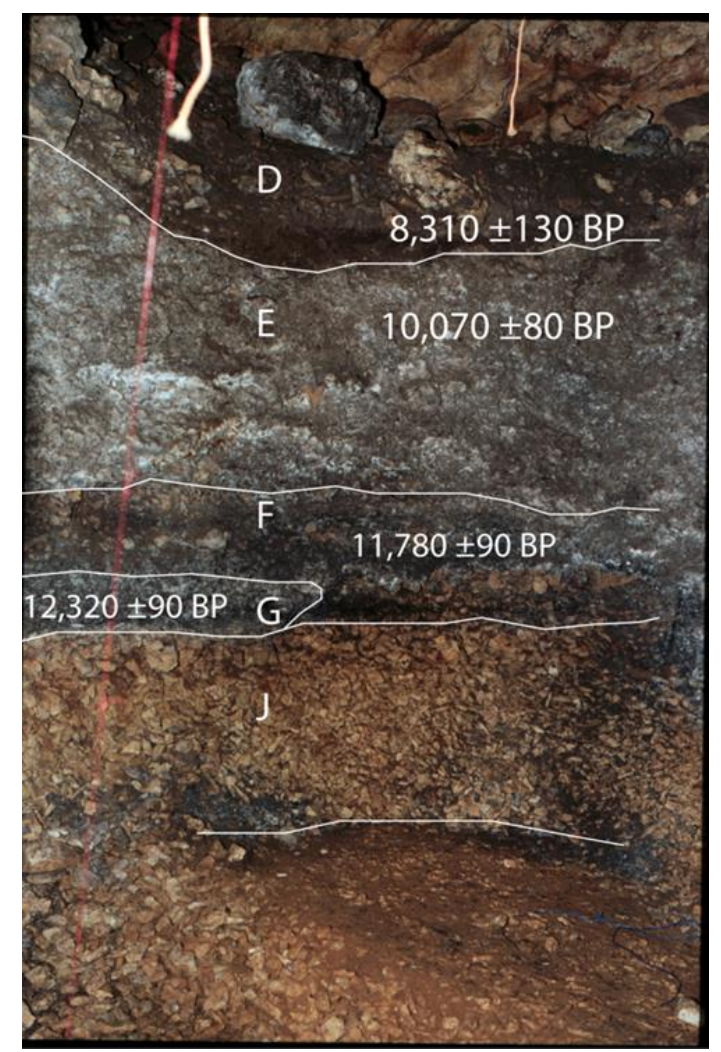

Figure 6.1: Stratigraphic Sequence of the Late Magdalenian layers of Lapa do Picareiro

\section{Layer F/G: Archaeological Context}

Layer F/G dates between 13,772 and 14,011 cal BP (Haws 2003; See APPENDIX I: Site Chronology). This layer was identified in the stratigraphy as possessing loose clasts with very little sediment present (Haws 2003). The most significant feature identified in this layer was a large hearth, nicknamed 'the bunny pit' due to the immense amount of rabbit bone recovered, that contained a large quantity of sediment, charcoal, fragmentary and burned bones, and lithic material (Haws 2003).

From Layer F/G 3,280 lithic artifacts were recovered (See Table 6.1). The predominant raw materials are chert (69.56\%), quartz (20.65\%), and quartzite 
(8.68\%). Technologically, it is dominated by chips $(\# 2,096=64.15 \%)$, flakes/flake fragments $(\# 512=15.67 \%)$, elongated blanks $(\# 444=13.59 \%)$, cores $(\# 67=$ $2.05 \%)$, preparatory and maintenance products $(\# 63=1.92 \%)$, and hammerstones $(\# 2=0.06 \%)$ that comprise the in situ knapping. The large amount of chips, chunks, hammerstones, anvils, and preparatory and maintenance products are indicative of in situ knapping and core maintenance and the pebbles/nodules indicate raw material selection.

\begin{tabular}{|l|c|c|c|c|c|}
\hline \multirow{2}{*}{$\begin{array}{c}\text { Technological } \\
\text { Type }\end{array}$} & \multicolumn{4}{|c|}{ Count by Raw Material } & \multirow{2}{*}{ Total } \\
\cline { 2 - 5 } & Chert & Quartz & Quartzite & Misc. & \\
\hline Flakes & 193 & 24 & 81 & 2 & 300 \\
\hline Flake fragments & 143 & 23 & 48 & 0 & 214 \\
\hline Blades & 8 & 0 & 2 & 0 & 10 \\
\hline Bladelets & 142 & 4 & 3 & 0 & 149 \\
\hline $\begin{array}{l}\text { Blade/bladelet } \\
\text { fragments }\end{array}$ & 192 & 18 & 7 & 0 & 217 \\
\hline Burin spalls & 53 & 6 & 9 & 0 & 68 \\
\hline $\begin{array}{l}\text { Prep. \& } \\
\text { maintenance }\end{array}$ & 38 & 1 & 24 & 0 & 63 \\
\hline Cores & 27 & 17 & 23 & 1 & 68 \\
\hline Hammerstones & 0 & 0 & 2 & 1 & 3 \\
\hline Anvils & 0 & 0 & 1 & 0 & 1 \\
\hline Pebbles/nodules & 0 & 0 & 5 & 0 & 5 \\
\hline Firecracks & 0 & 0 & 8 & 0 & 8 \\
\hline Chunks & 29 & 10 & 32 & 7 & 78 \\
\hline Chips & 1,301 & 535 & 258 & 2 & 2,096 \\
\hline \multicolumn{1}{|c|}{ Total } & 2,126 & 638 & 503 & $\mathbf{1 3}$ & $\mathbf{3 , 2 8 0}$ \\
\hline
\end{tabular}

Table 6.1: Layer $\mathrm{F} / \mathrm{G}$ assemblage inventory by raw materials 


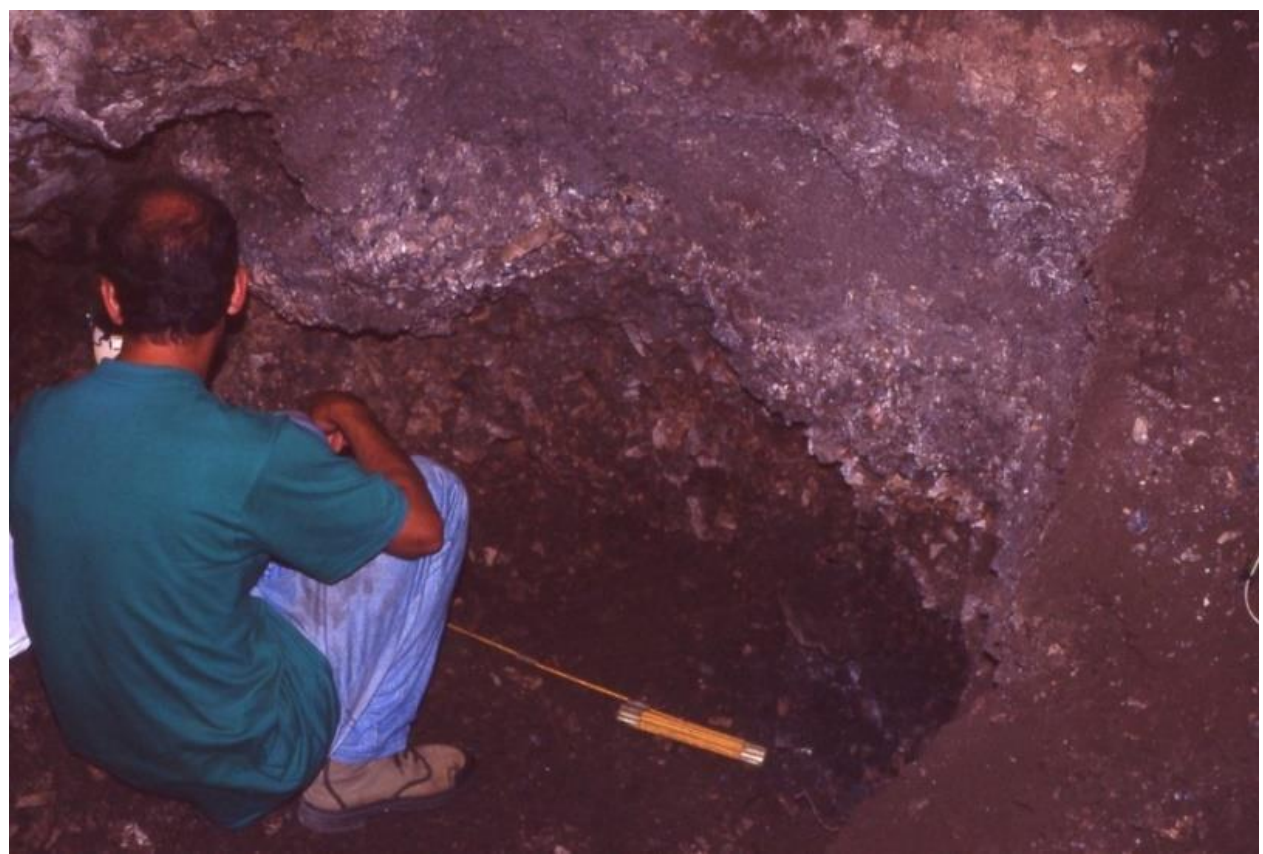

Figure 6.2: António Carvalho in 1994 exposing the large hearth nicknamed 'the bunny pit' in Layer F/G

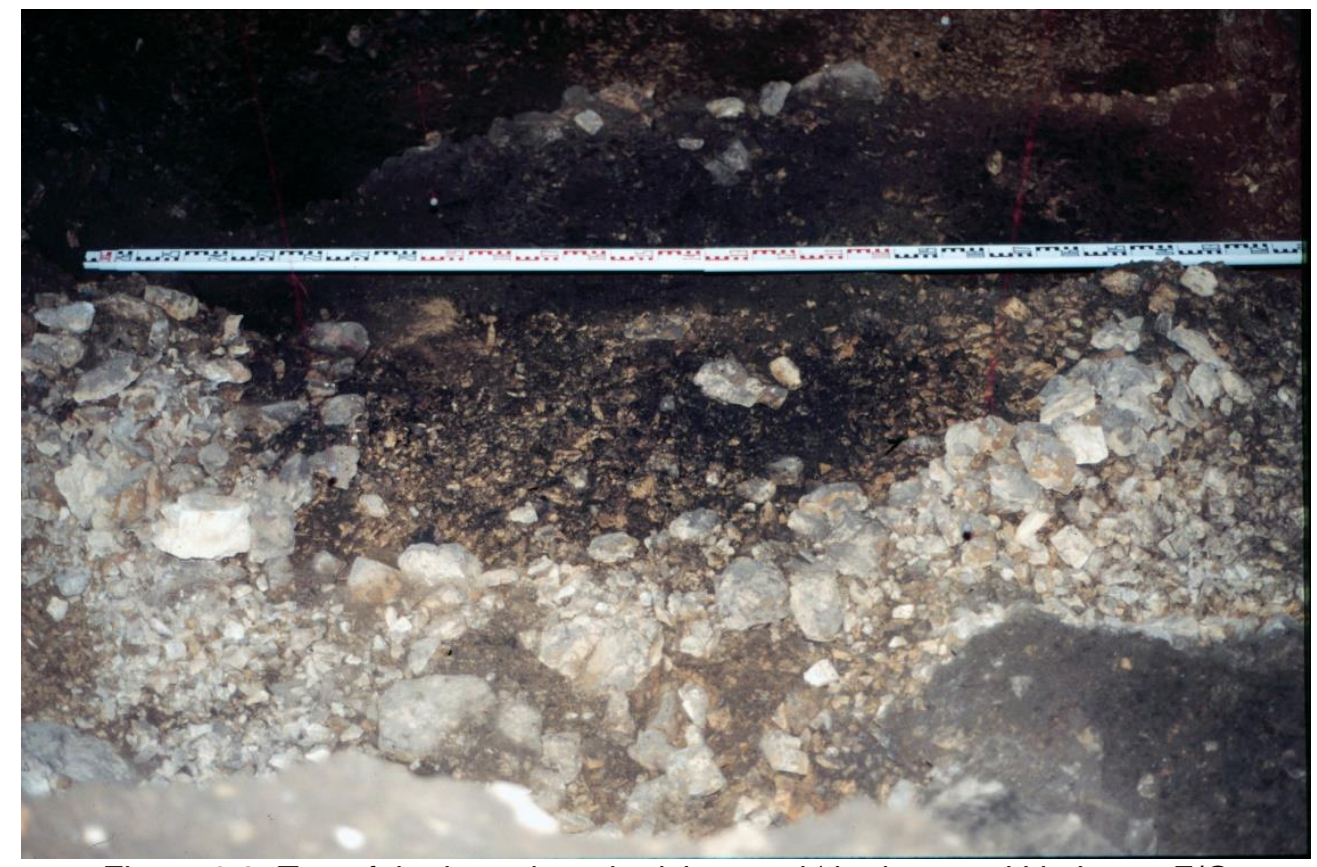

Figure 6.3: Top of the large hearth nicknamed 'the bunny pit' in Layer F/G

\section{Artifact Density}

The artifacts recovered from Layer F/G are plotted on a plan layout of the cave (Figures 6.4 and 6.5); from these, there are interesting trends in general artifact density that can be identified, specifically in the E5, E6, and F5 units. 
These three units represent the location of the large hearth nicknamed 'the bunny pit'. It is apparent from these densities that the recovered lithic materials were all being reduced, used, and discarded within the same areas.

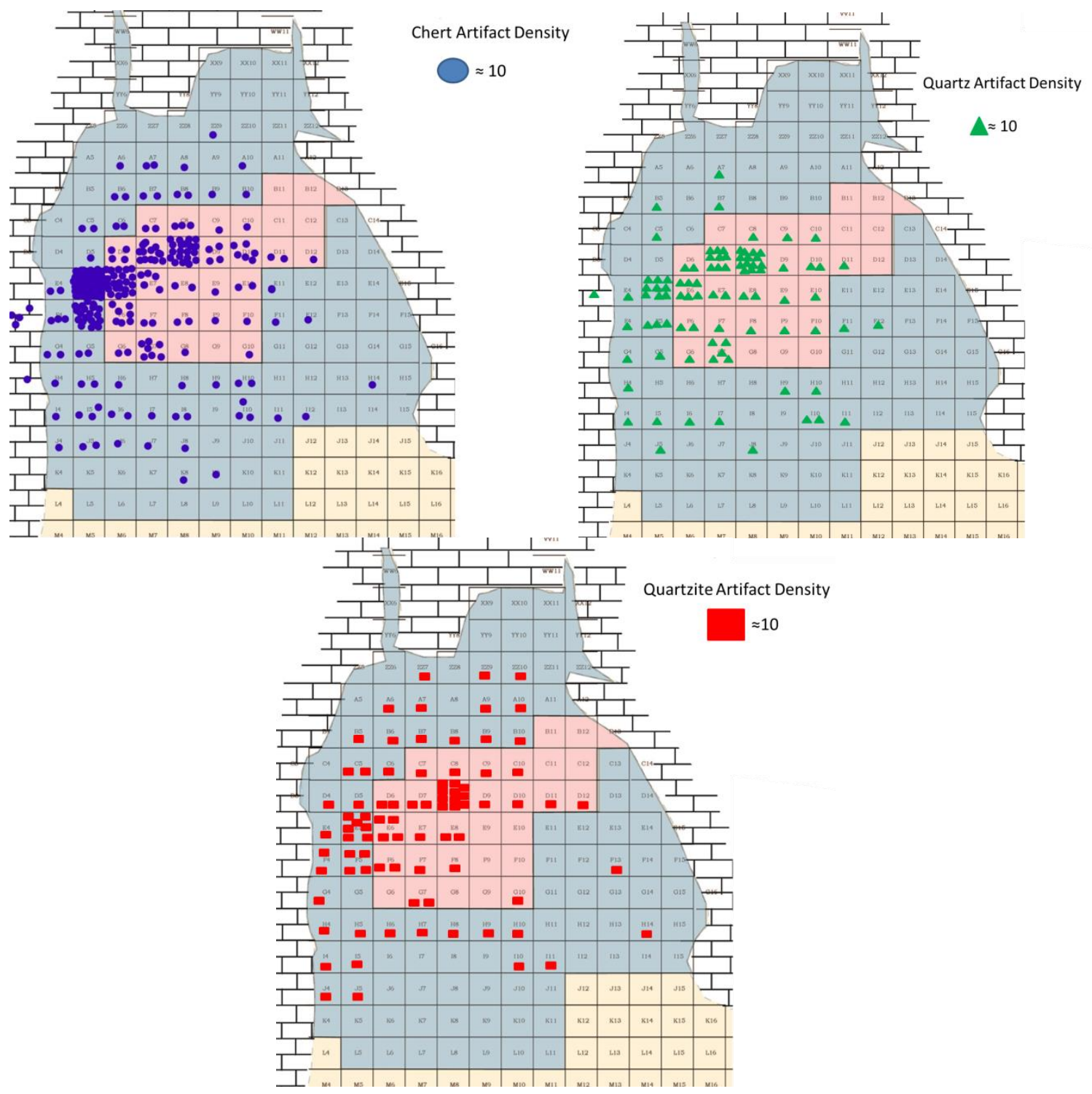

Figure 6.4: Relative density of raw materials in Layer F/G. Each marker is roughly equal to 10 artifacts. 


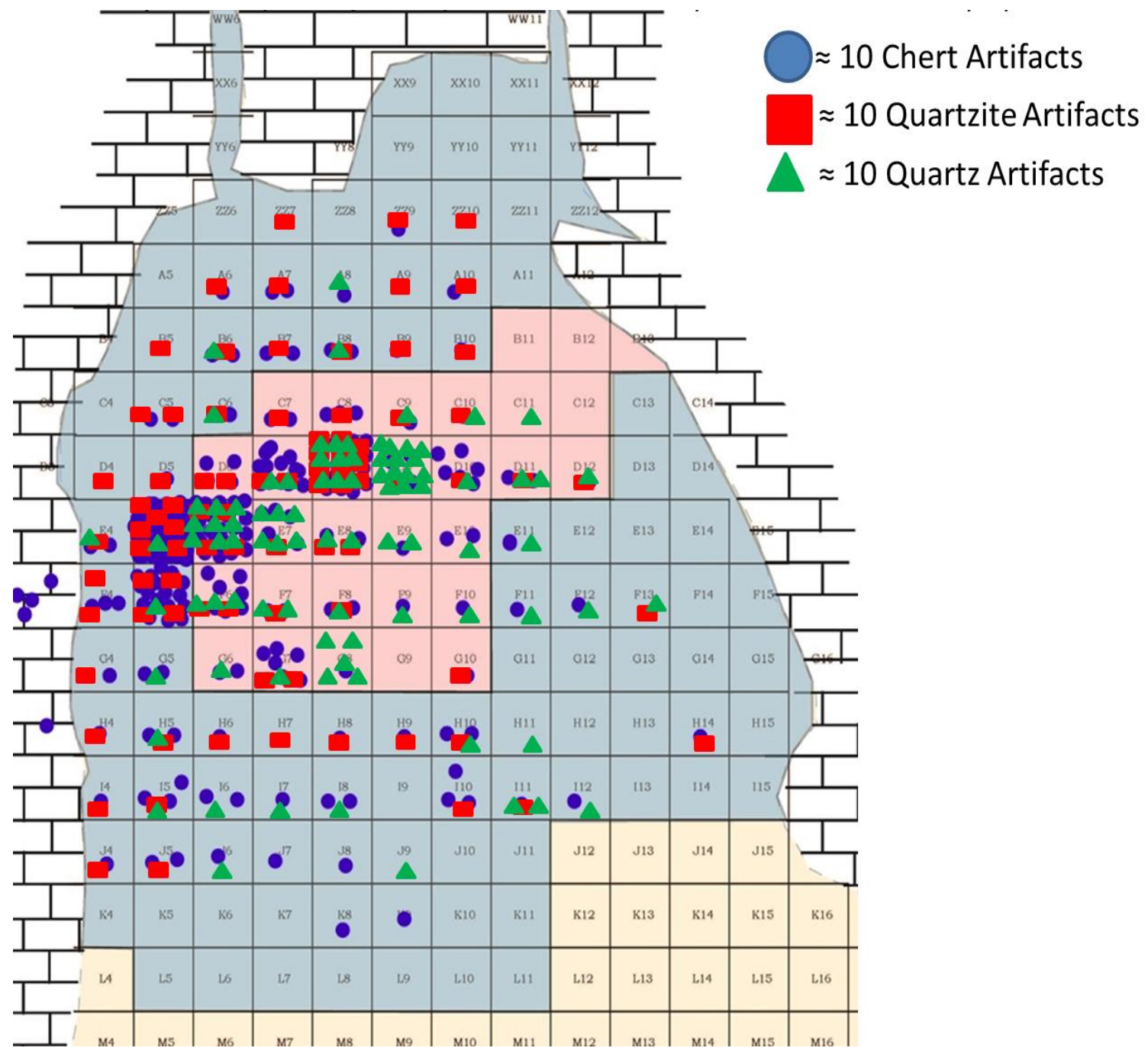

Figure 6.5: Relative density of raw materials in Layer F/G. Each marker roughly represents 10 artifacts.

\section{Layer F/G: Cores}

\begin{tabular}{|c|c|c|c|c|c|}
\hline & Chert & Quartz & Quartzite & Sandstone & Total \\
\hline Count & 27 & 17 & 23 & 1 & $\mathbf{6 8}$ \\
\hline$\%$ & 39.70 & 25.00 & 33.82 & 1.47 & $\mathbf{9 9 . 9 9 \%}$ \\
\hline Weight (g) & 513.54 & 448.75 & $6,543.69$ & 285.50 & $\mathbf{7 , 7 9 1 . 4 8}$ \\
\hline
\end{tabular}

Table 6.2: Inventory of cores by raw material 


\section{$\underline{\text { Chert }}$}

\begin{tabular}{|c|c|c|}
\hline Core Type & Count & \% of those in chert \\
\hline Bipolar & 3 & 11.11 \\
\hline Prismatic & 14 & 51.85 \\
\hline Multi-directional & 8 & 29.62 \\
\hline Core fragments & 2 & 7.4 \\
\hline Total & $\mathbf{2 7}$ & $\mathbf{9 9 . 9 8 \%}$ \\
\hline
\end{tabular}

Table 6.3: Inventory of core types in chert

The chert cores produced bladelets mostly through prismatic reduction.

This is shown by the predominance of prismatic cores with bladelet detachments (\#14 = 51.85\%) and corroborated by the bladelet to core production ratio [MNI of bladelets (213): cores (14)], meaning there is an average production of 15.21 bladelets per prismatic core. Chert cores were also used however to produce flakes; shown by 10 cores with expanding and/or intermediate flake scar detachments and corroborated by the flake to core production ratio [MNI of flakes (240): cores (11)], meaning there is an average production of 21.81 flakes per core with expanding and/or intermediate flake scars. The ratio between prismatic cores to those producing flakes in 1.27 , meaning that for every flake there is 1.27 bladelets being produced. Nevertheless, at least some of these, along with bipolar and chunks might have represented prismatic cores that, as they reached an exhausted stage of exploitation, experienced a shift in production strategy towards flake blanks production, for a more opportunistic and expedient means producing useable cutting edges. This seems to be corroborated by the $46.11 \%$ of flakes of small size being less than $20 \mathrm{~mm}$ in length. This is also corroborated by the low amount of cortex on the cores, as all cores have less than $50 \%$ cortex. 


\section{$\underline{\text { Quartz }}$}

\begin{tabular}{|c|c|c|}
\hline Core Type & Count & \% of those in quartz \\
\hline Bipolar & 10 & 58.82 \\
\hline Prismatic & 2 & 11.76 \\
\hline Multi-directional & 2 & 11.76 \\
\hline Core fragments & 2 & 11.76 \\
\hline Tested pebble & 1 & 5.88 \\
\hline Total & $\mathbf{1 7}$ & $\mathbf{9 9 . 9 8 \%}$ \\
\hline
\end{tabular}

Table 6.4: Inventory of core types in quartz

The quartz cores produced flakes mostly through bipolar reduction. This is shown by the predominance of bipolar cores with flake detachments $\# 10=$ $58.82 \%)$. These cores, much like those in chert, reached a stage of exploitation that required a shift in production strategy, from bladelet production, [(MNI of bladelets (7): cores (2)] meaning there is an average production of 3.5 bladelets per prismatic core, to flake blank production, [MNI of flakes (\#36): cores (\#10)], meaning that there is an average production of 3.6 flakes per core, due to the need to produce cutting edges from these small cores. This seems to be corroborated by the $45.08 \%$ of small sized flakes with less than $20 \mathrm{~mm}$ in length. This is also corroborated by the low amount of cortex, as $88.23 \%$ of the cores have less than $50 \%$ cortex.

Quartzite

\begin{tabular}{|c|c|c|}
\hline Core Type & Count & $\begin{array}{c}\text { \% of those in } \\
\text { quartz }\end{array}$ \\
\hline Prismatic & 3 & 13.04 \\
\hline Multi-directional & 1 & 4.34 \\
\hline Core fragments & 5 & 21.73 \\
\hline Chopper & 14 & 60.86 \\
\hline Total & $\mathbf{2 3}$ & $\mathbf{9 9 . 9 7 \%}$ \\
\hline
\end{tabular}

Table 6.5: Inventory of core types in quartzite

The quartzite cores were largely used to produce flakes. These cores were reduced by the direct knapping of a water worn pebble without any 
preparation; the nodules were selected based upon the possession of a naturally flat platform. These types of artifacts are traditionally called choppers. This is shown by the predominance of choppers with flake detachments $(\# 14=60.86 \%)$. [MNI of flakes (\#93)/cores (\#14)] gives an average ratio of 6 flakes by core. Of these cores, $65.21 \%$ of them possess more than $50 \%$ cortex and $85.18 \%$ of the flakes being over $20 \mathrm{~mm}$ in length. Bladelets were not intensively produced in this material, corroborated to the low bladelet to core ratio [MNI of bladelets (5): cores (14)].

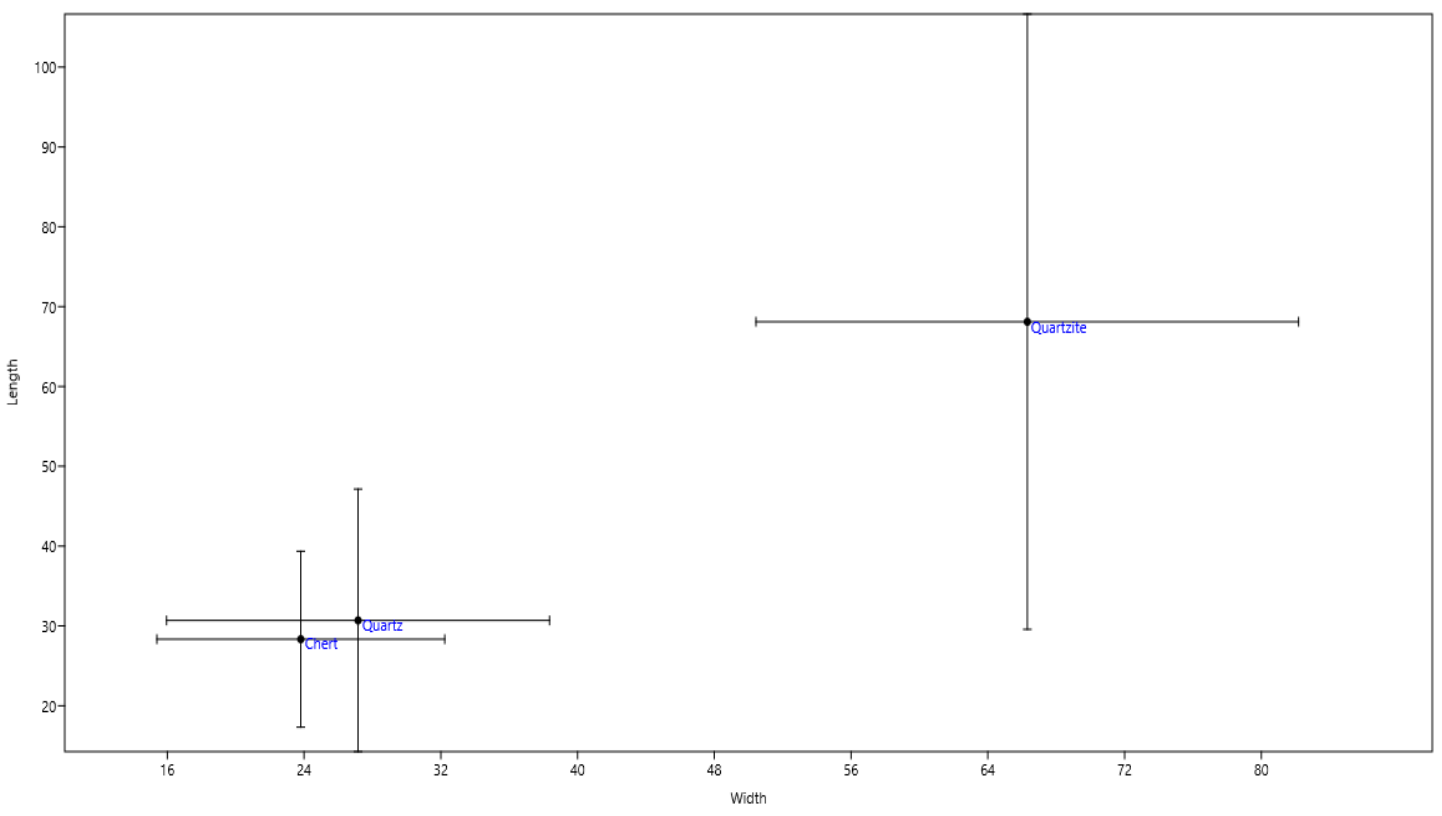

Figure 6.6: Average core size by raw material with standard deviation 


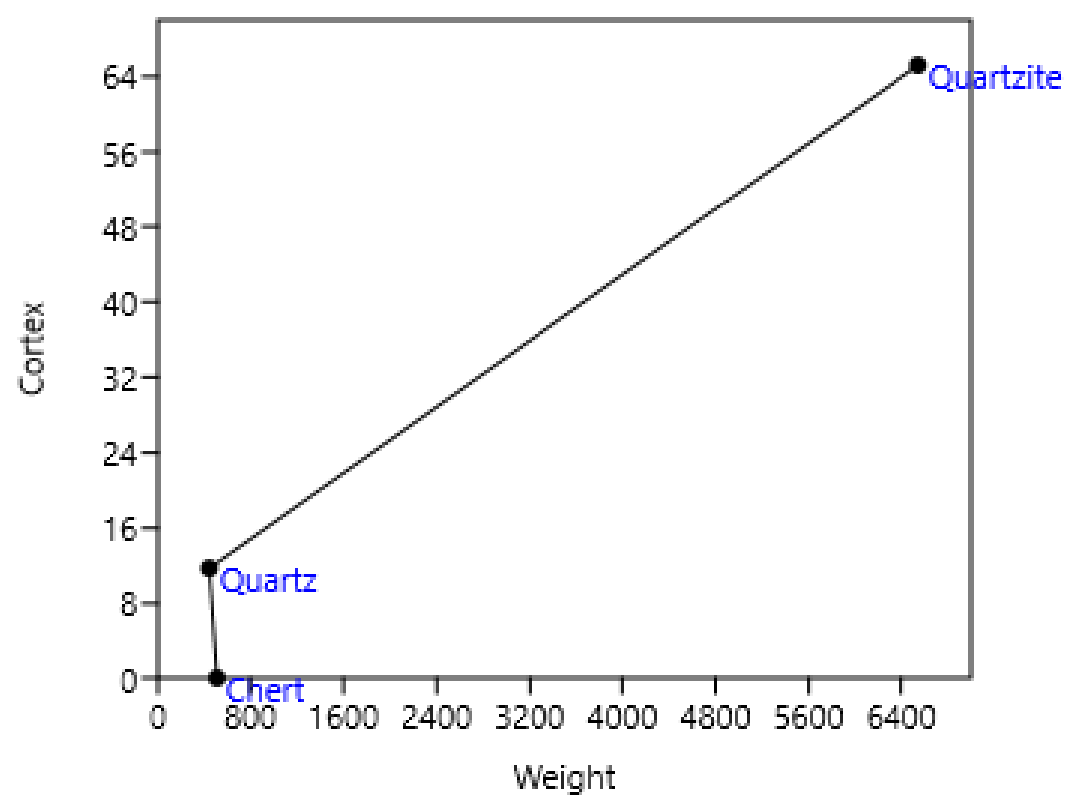

Figure 6.7: Core volume to cortical presence comparison

Figure 6.6 shows the distribution of the average size of primary raw materials cores. From this, it is shown that quartzite cores possess larger dimensions while chert and quartz are small in size. Figure 6.7 represented the volume of the cores versus their cortical representation. Looking at these two figures together, it is evident that chert and quartz were exploited in a similar manner or at the time of procurement were of similar size. The chert and quartz cores were reduced to very small dimensions with little to no cortex present, while the quartzite cores remained largely cortical, this could be due to the utility of the core itself as a tool. The variation in core size has an influence on blank size production (See Figure 6.8); quartzite flakes, much like quartzite cores, have larger dimensions than that of chert and quartz. 


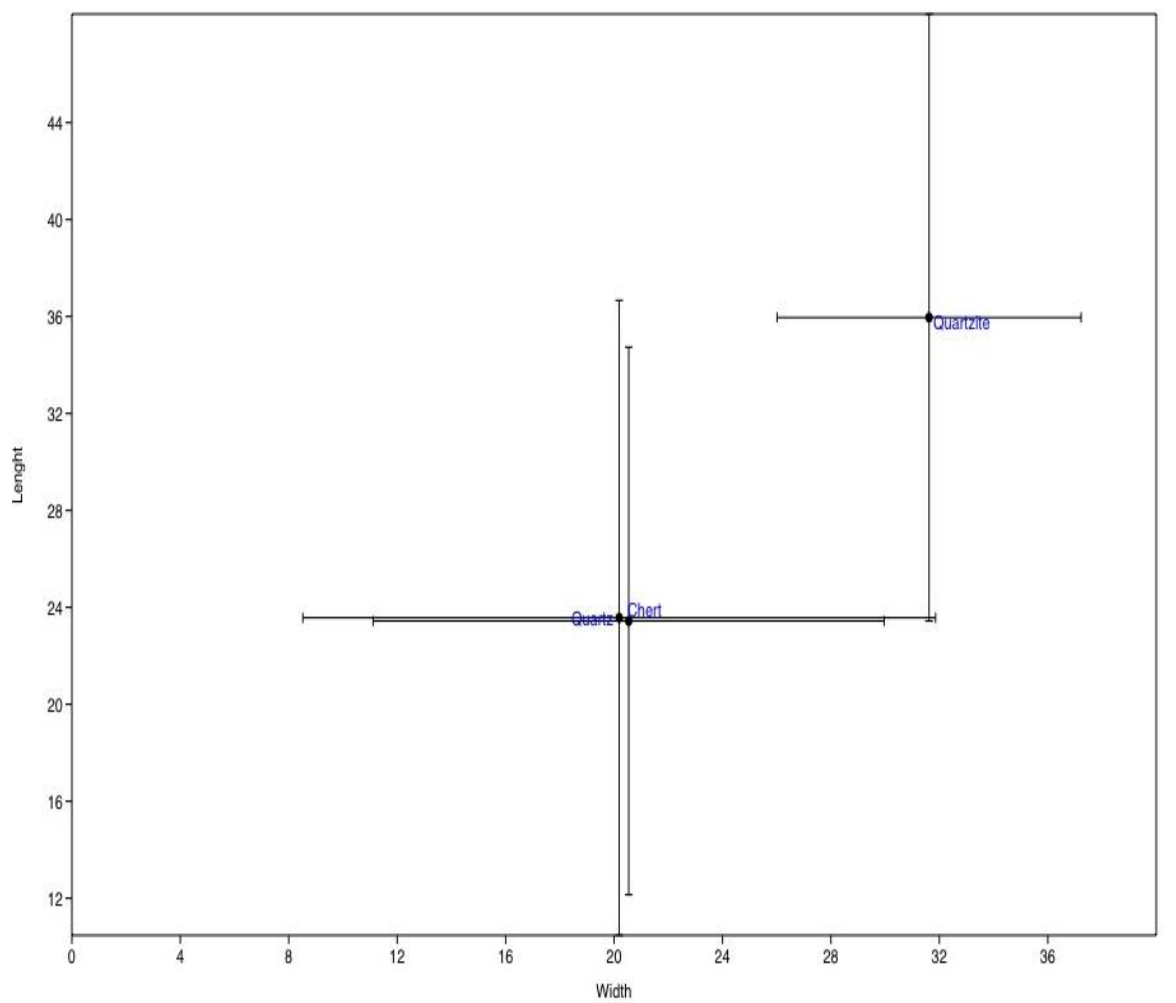

Figure 6.8: Average flake blank size by raw material with standard deviation

\section{Layer F/G: Blanks}

The MNI for blanks (flakes, blades, and bladelets) that make up Layer F/G represent 604 artifacts. Figure 6.9 demonstrates the relative distribution of blank types by raw material. Flakes represent the highest production rate, being present in all three raw materials. 


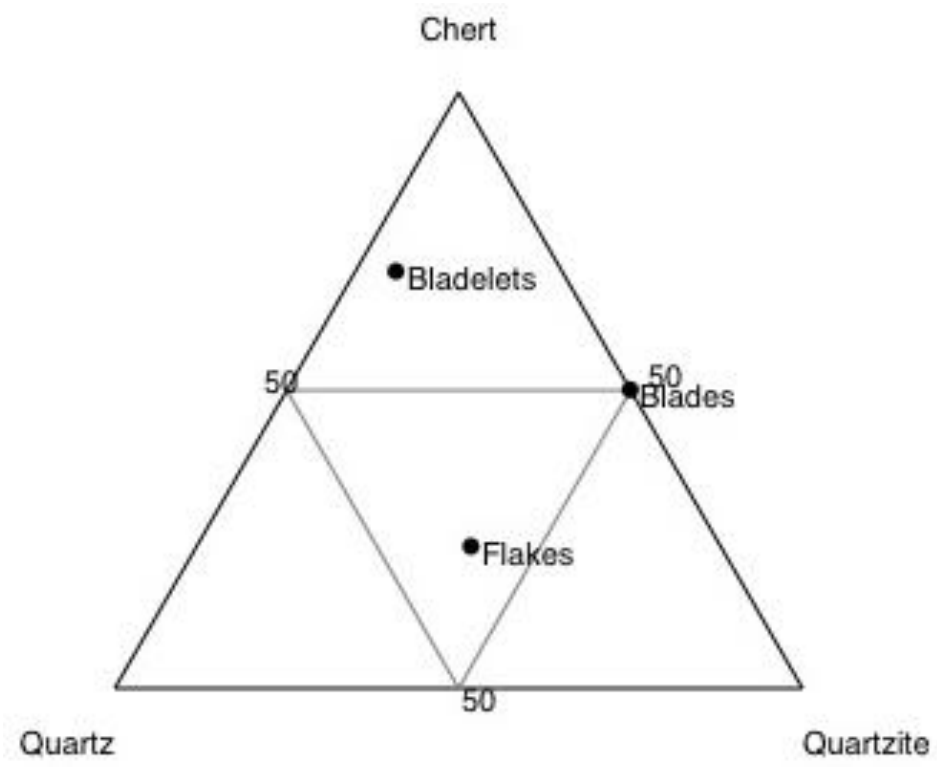

Figure 6.9: Relative distribution of blank types

However, there is a larger relative frequency in quartz and quartzite than in chert, this is because chert was also used for intensive bladelet production. Bladelets, while being the second most produced blank type, are produced most predominantly in chert, with a small amount being produced in quartz. Blades, being the least represented blank type were produced relatively equally between chert and quartzite, but not in quartz. Thus, chert was producing bladelets and flake blanks relatively equally; quartz was producing flake blanks and some bladelets, while quartzite was used almost exclusively for flake production. Figure 6.10 displays the distribution of average flake blank size by raw material. 


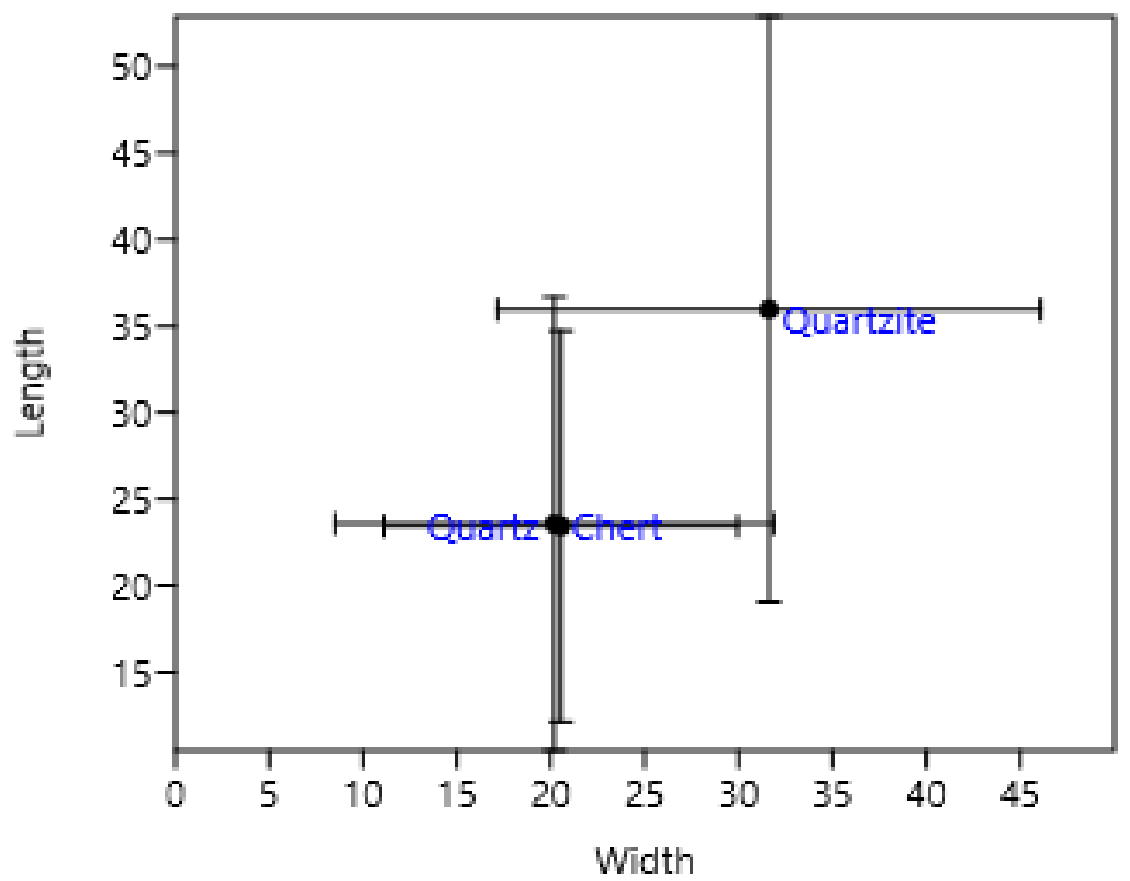

Figure 6.10: Distribution of average flake blank size by raw material

Looking back at figure 6.7 and then at 6.10 , based upon production of blank type, volume, and representation of cortex it is discernable that quartz was treated similarly to chert. Thus, from these two figures, and from the information gathered from the cores, blanks were produced through intensive reduction on chert and quartz, and less intensively on quartzite. 


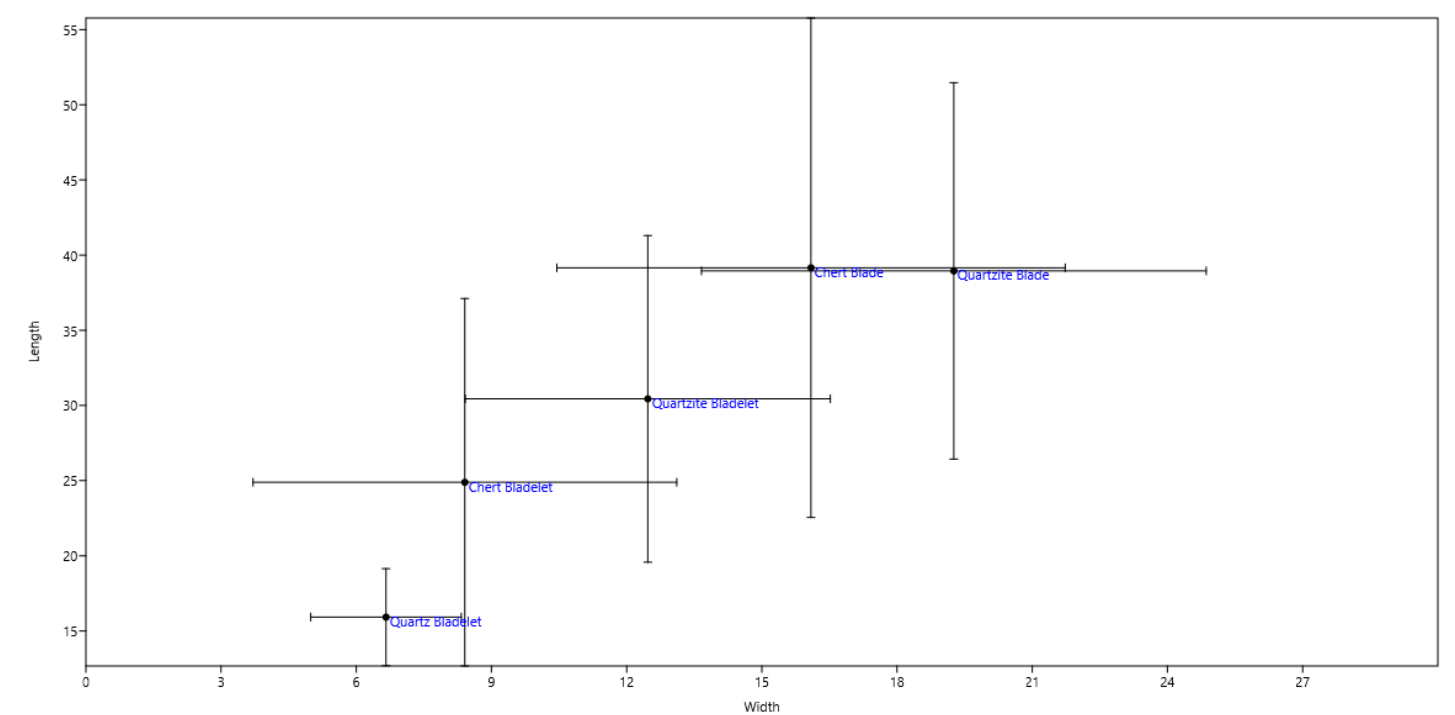

Figure 6.11: Average blade and bladelet size distribution by raw material with standard deviation

Figure 6.11 demonstrates the variation in average size variation between blades and bladelets. This type of variation is indicative of two different categories of elongated blanks, thus reaffirming that there is indeed blade and bladelets being produced at the site.

Looking at the dimensions of the elongated blanks (Figures 6.12, 6.13, and 6.14), it can be determined if there is one or more production strategies employed in their production. First (Figure 6.12), is that of quartzite. The histogram demonstrates a elongate unimodal curve, indicating that there is only one group of elongated quartzite blanks being produced. Second, (Figure 6.13) is quartz blanks. The histogram clearly demonstrates a pronounced unimodal curve, again indicating that there is only one group of elongated blank types being produced. Finally (Figure 6.14) represents chert elongated blanks. This histogram, demonstrates an elongated unimodal curve with a significant peak that suggests there may be two production groups of elongated blanks, one larger than the other, but still within the standard bladelet threshold of $12 \mathrm{~mm}$. 


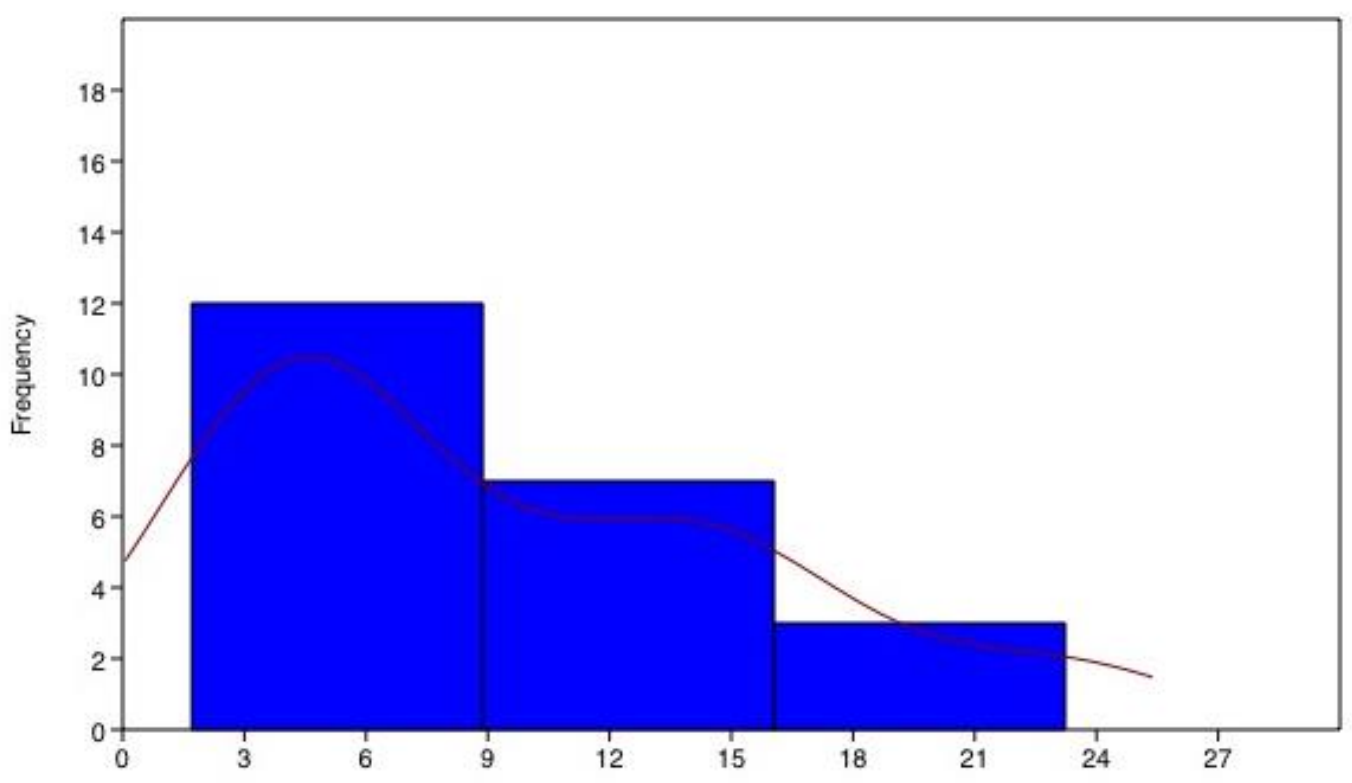

Figure 6.12: Frequency of elongated quartzite blanks

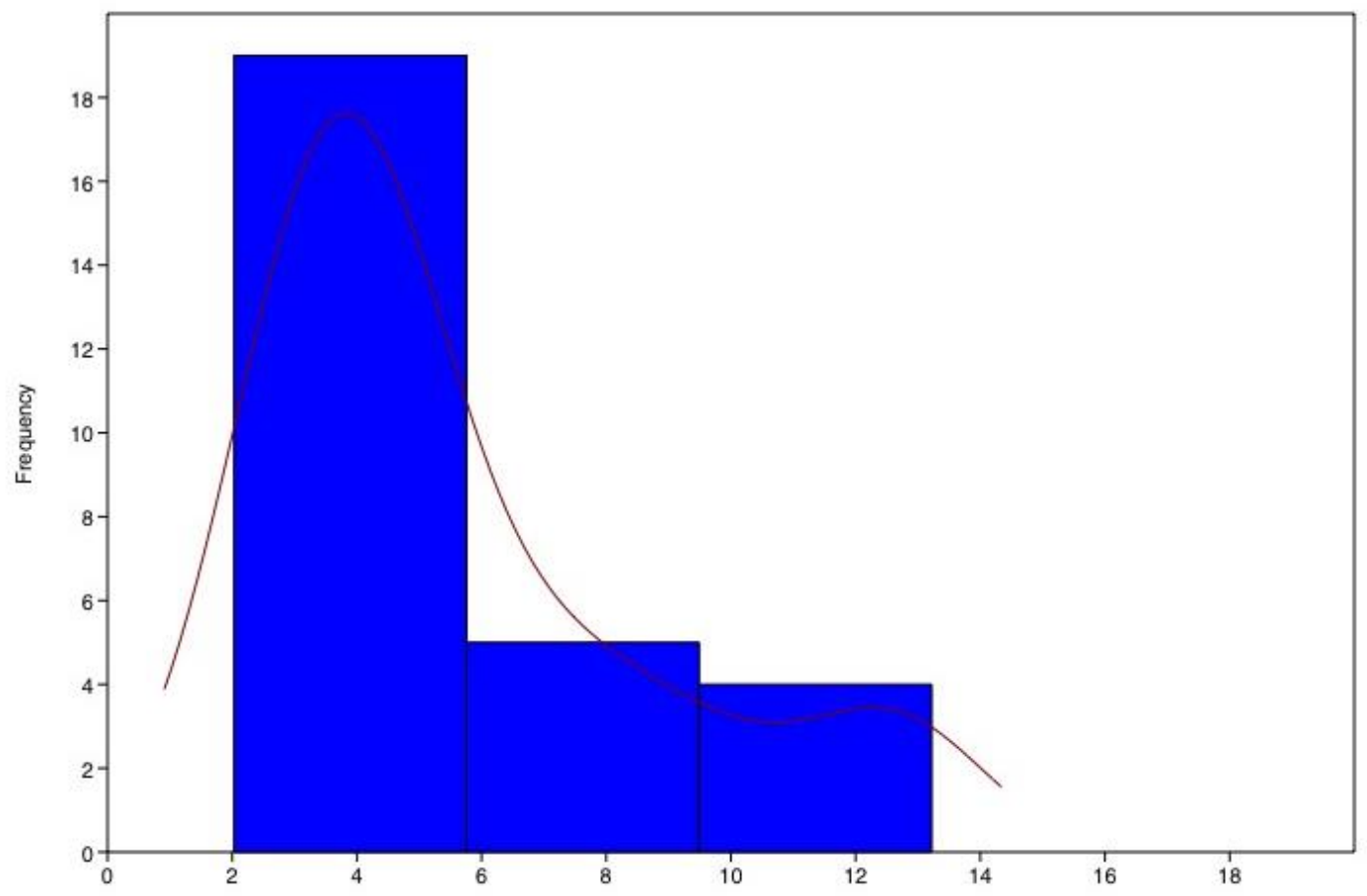

Figure 6.13: Frequency of elongated quartz blanks 


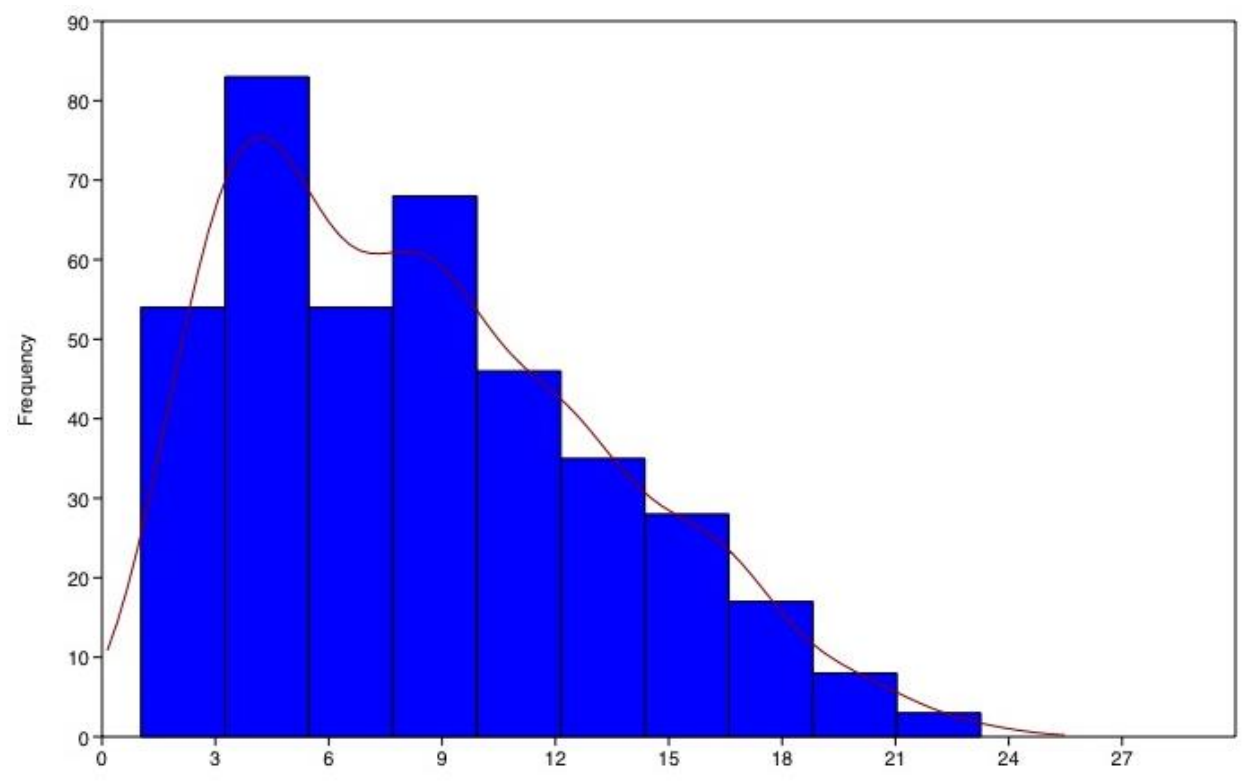

Figure 6.14: Frequency of elongated chert blanks

Layer F/G: Burin Spalls

\begin{tabular}{|c|c|c|c|c|c|}
\hline \multicolumn{2}{|c|}{} & Chert & Quartz & Quartzite & Total \\
\hline \multirow{3}{*}{ Platform Type } & Pointed & 1 & 0 & 0 & $\mathbf{1}$ \\
\cline { 2 - 6 } & Plain & 27 & 2 & 3 & $\mathbf{3 2}$ \\
\cline { 2 - 6 } & Faceted & 21 & 4 & 6 & $\mathbf{3 1}$ \\
\cline { 2 - 6 } & Indeterminate & 4 & 0 & 0 & $\mathbf{4}$ \\
\hline \multirow{2}{*}{ Dorsal Scar Pattern } & Unidirectional & 53 & 6 & 9 & $\mathbf{6 8}$ \\
\hline \multirow{3}{*}{ Termination } & Feather & 38 & 1 & 8 & $\mathbf{4 7}$ \\
\cline { 2 - 6 } & Hinge & 1 & 0 & 0 & $\mathbf{1}$ \\
\cline { 2 - 6 } & Step & 14 & 5 & 1 & $\mathbf{2 0}$ \\
\hline \multicolumn{2}{|c|}{ Total } & $\mathbf{5 3}$ & $\mathbf{6}$ & $\mathbf{9}$ & \\
\hline
\end{tabular}

Table 6.6: Inventory of burin spalls by raw material

The 68 burin spalls were produced on chert $(\# 53=77.94 \%=20.82 \mathrm{~g})$, quartz $(\# 6=8.82 \%=0.89 \mathrm{~g})$, and quartzite $(\# 9=13.23 \%=3.69 \mathrm{~g})$. None of the burin spalls have cortex. Taking their average dimensions in each raw material and comparing them to the same average measurements in bladelets, then end result is Figure 6.15. 


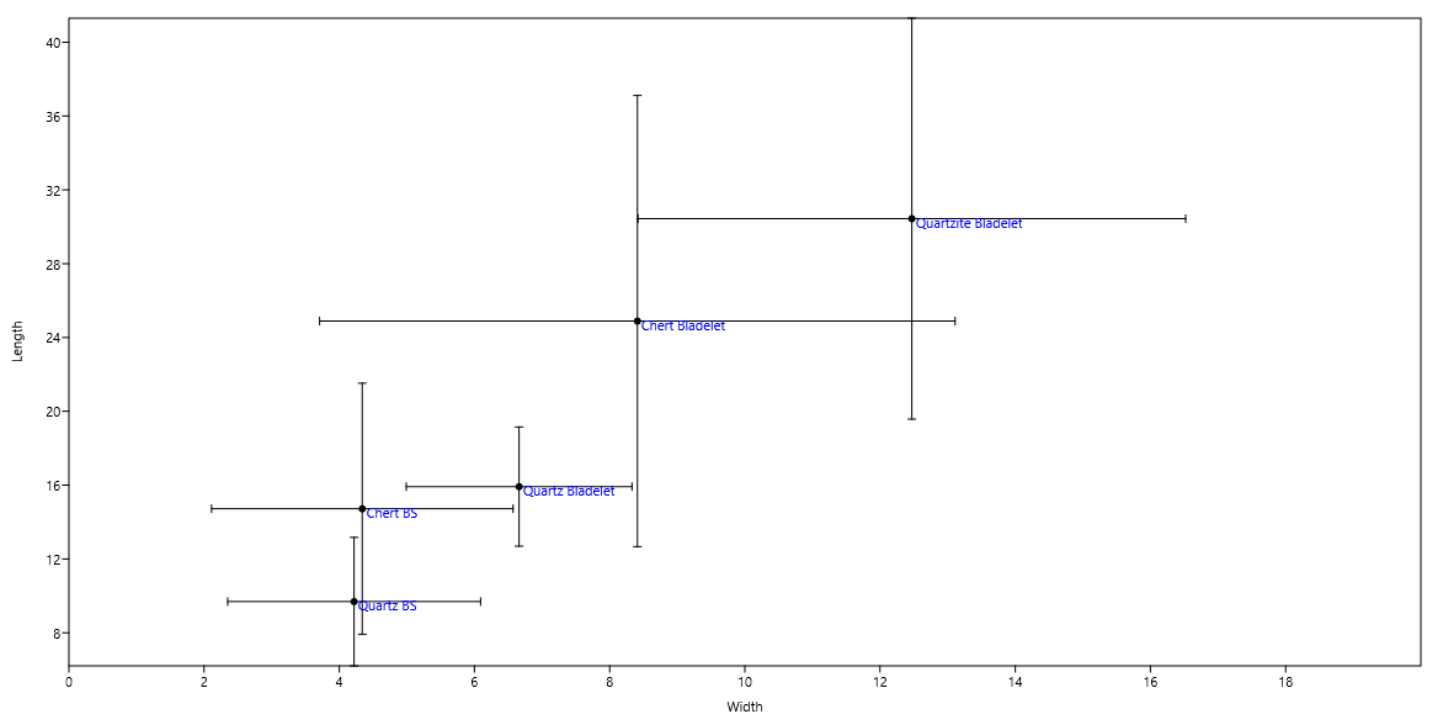

Figure 6.15: Average bladelet and burin spall size distribution by raw material with standard deviation

Length and width, while being variable across the various classes, are relatively proportionate in all raw materials by artifact type. Thickness however is where they are less proportionate. Despite being smaller in length and width, the thicknesses of the burin spalls are proportionate to their longer and wider counterparts in chert. Thus, instead of being elongated and thin like the bladelets, the burin spalls are short and thick. These short, thick, multi- edged implements were ideal for use as hunting barbs (Zilhão 1997a:157). Further analysis will need to be conducted to determine if the burin spalls recovered were used via residue analysis and/or identification of impact fractures. 
Layer F/G: Retouched Tools

\begin{tabular}{|c|ccc|c|}
\hline & Chert & Quartz & Quartzite & $\begin{array}{c}\text { Total by typological } \\
\text { assignment }\end{array}$ \\
\hline Backed Bladelets & 76 & 11 & 0 & 87 \\
Burins & 48 & 1 & 0 & 49 \\
Composite Tool & 5 & 0 & 0 & 5 \\
Denticulate & 4 & 0 & 1 & 5 \\
Notch & 16 & 4 & 1 & 21 \\
Perforator & 1 & 1 & 0 & 2 \\
Side Scraper & 7 & 0 & 0 & 7 \\
Thick Endscraper & 7 & 1 & 0 & 8 \\
Thin Endscraper & 14 & 0 & 0 & 14 \\
Truncation & 11 & 1 & 1 & 13 \\
\hline Total by Raw Material & 189 & 19 & 3 & 211 \\
\hline
\end{tabular}

Table 6.7: Retouched tool inventory

The 211 retouched tools were produced on chert $(\# 189=89.57 \%=$

$820.21 \mathrm{~g})$, quartz $(\# 19=9.00 \%=70.52 \mathrm{~g})$, and quartzite $(\# 3=1.42 \%=28.1 \mathrm{~g})$.

The retouched tool types identified consist of backed bladelets ( $\# 87=41.23 \%)$,

burins $(\# 49=23.22 \%)$, notches $(\# 21=9.95 \%)$, thin endscrapers $(\# 13=6.16 \%)$,

truncations $(\# 13=6.16 \%)$, thick endscrapers $(\# 8=3.79 \%)$, side scrapers $(\# 7=$ $3.31 \%)$, composite tools ( $\# 5=2.36 \%$ ), denticulates $(\# 5=2.36 \%)$, and a perforator $(\# 2=0.94 \%)$.

\section{Backed Bladelets}

\begin{tabular}{|c|c|c|c|c|c|}
\hline & & Chert & Quartz & Quartzite & Total \\
\hline \multirow{3}{*}{ Blank Type } & Bladelet & 40 & 1 & 0 & 41 \\
\hline & Blade/bladelet fragment & 29 & 10 & 0 & 39 \\
\hline & Burin Spall & 7 & 0 & 0 & 7 \\
\hline \multirow{5}{*}{ Platform Type } & Pointed & 4 & 0 & 0 & 4 \\
\hline & Plain & 24 & 1 & 0 & 25 \\
\hline & Faceted & 23 & 0 & 0 & 23 \\
\hline & Indeterminate & 3 & 0 & 0 & 3 \\
\hline & Unknown & 22 & 10 & 0 & 32 \\
\hline \multirow{3}{*}{ Dorsal Scar Pattern } & Unidirectional & 41 & 1 & 0 & 42 \\
\hline & Bidirectional & 7 & 0 & 0 & 7 \\
\hline & Unknown & 28 & 10 & 0 & 38 \\
\hline \multirow{5}{*}{ Termination } & Feather & 48 & 8 & 0 & 56 \\
\hline & Hinge & 0 & 0 & 0 & 0 \\
\hline & Plunge & 1 & 0 & 0 & 1 \\
\hline & Step & 7 & 0 & 0 & 7 \\
\hline & Unknown & 20 & 3 & 0 & 23 \\
\hline \multicolumn{2}{|c|}{ Total } & 76 & 11 & 0 & \\
\hline
\end{tabular}

Table 6.8: Inventory of backed bladelets by raw material 
The backed bladelet assemblage is composed $87.35 \%$ by chert and $12.64 \%$ by quartz. There were no backed bladelets found in quartzite (see Table 6.8). Of these, $47.12 \%$ are on bladelets, $8.04 \%$ on burin spalls, and $44.82 \%$ on blade/bladelet fragments. The high percentage of fragmentary implements could be the result of use and discard; however this would have to be investigated through further analysis. None of these possessed any cortex, thus these tools were detached when the core was already in an advanced stage of reduction but before being exhausted. These backed bladelets are often interpreted as hunting tips and barbs (see Table 6.9; Zilhão 1997a:157), thus it can be inferred that the site had some connection to hunting activities.

\begin{tabular}{|c|c|c|c|c|c|}
\hline \multicolumn{1}{|c|}{} & Chert & Quartz & Quartzite & Total \\
\hline \multirow{4}{*}{$\begin{array}{c}\text { Typological } \\
\text { Designation }\end{array}$} & Microgravette (51a) & 2 & 0 & 0 & $\mathbf{2}$ \\
\cline { 2 - 6 } & Rectilinear Backed Bladelet (85a) & 17 & 1 & 0 & $\mathbf{1 8}$ \\
\cline { 2 - 6 } & Double backed bladelet (85d) & 2 & 0 & 0 & $\mathbf{2}$ \\
\cline { 2 - 6 } & Fragment of backed bladelet (85f) & 25 & 9 & 0 & $\mathbf{3 4}$ \\
\cline { 2 - 6 } & Truncated backed bladelet (86a) & 8 & 0 & 0 & $\mathbf{8}$ \\
\cline { 2 - 6 } & Denticulated backed bladelet (88) & 1 & 0 & 0 & $\mathbf{1}$ \\
\cline { 2 - 6 } & Backed bladelet w/ Notch (89) & 7 & 1 & 0 & $\mathbf{7}$ \\
\cline { 2 - 6 } & Dufor bladelet (90a) & 3 & 0 & 0 & $\mathbf{3}$ \\
\hline & Fusiforme point (91d) & 11 & 0 & 0 & $\mathbf{1 1}$ \\
\hline
\end{tabular}

Table 6.9: Inventory of backed bladelet typologies 
Burins

\begin{tabular}{|c|c|c|c|c|c|}
\hline \multicolumn{1}{|c|}{} & Chert & Quartz & Quartzite & Total \\
\hline \multirow{4}{*}{ Blank Type } & Blade & 2 & 0 & 0 & $\mathbf{2}$ \\
\cline { 2 - 6 } & Blade/bladelet fragment & 7 & 0 & 0 & $\mathbf{7}$ \\
\cline { 2 - 6 } & Bladelet & 4 & 0 & 0 & $\mathbf{4}$ \\
\cline { 2 - 6 } & Burin spall & 3 & 0 & 0 & $\mathbf{3}$ \\
\cline { 2 - 6 } & Flake & 13 & 1 & 0 & $\mathbf{1 4}$ \\
\cline { 2 - 6 } & Flake fragment & 16 & 0 & 0 & $\mathbf{1 6}$ \\
\cline { 2 - 6 } & Prep. \& maint. product & 2 & 0 & 0 & $\mathbf{2}$ \\
\hline \multirow{4}{*}{ Platform } & Chunk & 1 & 0 & 0 & $\mathbf{1}$ \\
\cline { 2 - 6 } & Cortical & 4 & 0 & 0 & $\mathbf{4}$ \\
\cline { 2 - 6 } & Plain & 13 & 0 & 0 & $\mathbf{1 3}$ \\
\cline { 2 - 6 } & Faceted & 12 & 1 & 0 & $\mathbf{1 3}$ \\
\cline { 2 - 6 } & Indeterminate & 18 & 0 & 0 & $\mathbf{1 8}$ \\
\hline Dorsal Scar & Unknown & 1 & 0 & 0 & $\mathbf{1}$ \\
\cline { 2 - 6 } & Unidirectional & 15 & 0 & 0 & $\mathbf{1 5}$ \\
\cline { 2 - 6 } & Multidirectional & 1 & 1 & 0 & $\mathbf{2}$ \\
\cline { 2 - 6 } & Cortical & 2 & 0 & 0 & $\mathbf{2}$ \\
\cline { 2 - 6 } & Bidirectional & 7 & 0 & 0 & $\mathbf{7}$ \\
\hline Termination & Unknown & 23 & 0 & 0 & $\mathbf{2 3}$ \\
\cline { 2 - 6 } & Feather & 10 & 1 & 0 & $\mathbf{1 1}$ \\
\cline { 2 - 6 } & Hinge & 2 & 0 & 0 & $\mathbf{2}$ \\
\cline { 2 - 6 } & Step & 2 & 0 & 0 & $\mathbf{2}$ \\
\hline & Unknown & 34 & 0 & 0 & $\mathbf{3 4}$ \\
\hline & Total & $\mathbf{4 8}$ & $\mathbf{1}$ & $\mathbf{0}$ & \\
\hline
\end{tabular}

Table 6.10: Inventory of burins

The burin assemblage is composed $97.95 \%$ of chert and $2.04 \%$ by quartz. There were no burins found on quartzite (see Table 6.10), this could be due to burins being the result of barb (burin spall) production for use as hunting implements, or could be seen as evidence of those in quartzite being taken away from the site. Table 6.6 shows that there are quartzite burin spalls that were recovered from the site (none with retouch; Table 6.8), thus either the quartzite burin spalls were brought to the site, or the burins from which they were produced were removed (or yet to be recovered) from the site; this would require 
further research and analysis. The burins were produced on a wide variety of debitage types, but most commonly on flake and flake fragments. $89.79 \%$ of the burins possessed no cortex, thus their blanks were likely produced when the core was in an advanced stage of reduction, but before being exhausted. These burins represent both domestic tools and cores for barb production (see Table 6.11; Zilhão 1997a:157), thus it can be inferred that the site had some connection to hunting and domestic activities.

\begin{tabular}{|c|c|c|c|c|c|}
\hline & & Chert & Quartz & Quartzite & Total \\
\hline \multirow{13}{*}{$\begin{array}{l}\text { Typological } \\
\text { designation }\end{array}$} & Burin on Truncation (19) & 1 & 0 & 0 & 1 \\
\hline & Dihedral straight burin (27) & 4 & 0 & 0 & 4 \\
\hline & Dihedral diverted burin (28) & 4 & 0 & 0 & 4 \\
\hline & Angled dihedral burin (29) & 9 & 0 & 0 & 9 \\
\hline & Angled burin on fracture (30a) & 11 & 0 & 0 & 11 \\
\hline & Burin on straight truncation (34) & 3 & 1 & 0 & 4 \\
\hline & Burin on oblique truncation (35) & 4 & 0 & 0 & 4 \\
\hline & Burin on concave truncation (36) & 1 & 0 & 0 & 1 \\
\hline & Burin on convex truncation (37) & 3 & 0 & 0 & 3 \\
\hline & $\begin{array}{c}\text { Transversal burin on lateral } \\
\text { truncation (38) }\end{array}$ & 3 & 0 & 0 & 3 \\
\hline & Transversal burin on notch (39) & 3 & 0 & 0 & 3 \\
\hline & Multiple burins on truncation (40) & 1 & 0 & 0 & 1 \\
\hline & Bassaler burin (44b) & 1 & 0 & 0 & 1 \\
\hline & Total & 48 & 1 & 0 & \\
\hline
\end{tabular}

Table 6.11: Inventory of burin typologies 


\section{Composite tools}

\begin{tabular}{|c|c|c|c|c|c|}
\hline & & Chert & Quartz & Quartzite & Total \\
\hline \multirow{4}{*}{ Blank Type } & Blade & 1 & 0 & 0 & $\mathbf{1}$ \\
\cline { 2 - 6 } & $\begin{array}{c}\text { Blade/bladelet } \\
\text { fragment }\end{array}$ & 1 & 0 & 0 & $\mathbf{1}$ \\
\cline { 2 - 6 } & Flake & 2 & 0 & 0 & $\mathbf{2}$ \\
\cline { 2 - 6 } & Flake fragment & 1 & 0 & 0 & $\mathbf{1}$ \\
\hline \multirow{4}{*}{ Platform Type } & Cortical & 1 & 0 & 0 & $\mathbf{1}$ \\
\cline { 2 - 6 } & Faceted & 1 & 0 & 0 & $\mathbf{1}$ \\
\cline { 2 - 6 } & Indeterminate & 1 & 0 & 0 & $\mathbf{1}$ \\
\cline { 2 - 6 } & Unknown & 2 & 0 & 0 & $\mathbf{2}$ \\
\hline \multirow{3}{*}{ Dorsal Scar } & Unidirectional & 1 & 0 & 0 & $\mathbf{1}$ \\
\cline { 2 - 6 } & Bidirectional & 2 & 0 & 0 & $\mathbf{2}$ \\
\cline { 2 - 6 } & Unknown & 2 & 0 & 0 & $\mathbf{2}$ \\
\hline Termination & Unknown & 5 & 0 & 0 & $\mathbf{5}$ \\
\hline \multirow{2}{*}{} & Total & $\mathbf{5}$ & $\mathbf{0}$ & $\mathbf{0}$ & \\
\hline
\end{tabular}

Table 6.12: Inventory of composite tools

The composite tools are all endscraper-burins made on chert. This combination could be the result of three scenarios: 1.) that they were both utilized for their capabilities as domestic tools, 2.) that both tool types were the result of barb production for hunting implements, or 3.) that while they could have produced barbs for hunting implements, they were also utilized for domestic activities. $80 \%$ of these tools were found to have no cortex, indicating that their blanks were produced when the core was in an advanced stage of reduction, but before being exhausted (see figure 6.13; Zilhão 1997a:157).

\begin{tabular}{|c|c|c|c|c|c|}
\hline \multicolumn{2}{|c|}{} & Chert & Quartz & Quartzite & Total \\
\hline Typological designation & $\begin{array}{c}\text { Burin and } \\
\text { endscraper } \\
(17)\end{array}$ & 5 & 0 & 0 & $\mathbf{5}$ \\
\hline Total & & $\mathbf{5}$ & $\mathbf{0}$ & $\mathbf{0}$ & \\
\hline
\end{tabular}

Table 6.13: Inventory of composite tool typologies 


\section{Denticulates}

\begin{tabular}{|c|c|c|c|c|c|}
\hline & & Chert & Quartz & Quartzite & Total \\
\hline \multirow{3}{*}{ Blank Type } & Bladelet & 1 & 0 & 0 & 1 \\
\hline & Flake & 3 & 0 & 0 & 3 \\
\hline & Flake fragment & 0 & 0 & 1 & 1 \\
\hline \multirow{4}{*}{ Platform Type } & Cortical & 1 & 0 & 0 & 1 \\
\hline & Faceted & 1 & 0 & 0 & 1 \\
\hline & Plain & 2 & 0 & 0 & 2 \\
\hline & Unknown & 0 & 0 & 1 & 1 \\
\hline \multirow{3}{*}{$\begin{array}{c}\text { Dorsal Scar } \\
\text { Pattern }\end{array}$} & Multidirectional & 1 & 0 & 0 & 1 \\
\hline & Bidirectional & 1 & 0 & 0 & 1 \\
\hline & Unknown & 2 & 0 & 1 & 3 \\
\hline \multirow{3}{*}{ Termination } & Unknown & 2 & 0 & 1 & 3 \\
\hline & Plunge & 1 & 0 & 0 & 1 \\
\hline & Hinge & 1 & 0 & 0 & 1 \\
\hline \multicolumn{2}{|c|}{ Total } & 4 & 0 & 1 & \\
\hline
\end{tabular}

Table 6.14: Inventory of denticulates

The denticulate class is comprised $80 \%$ of chert artifacts and $20 \%$ of quartzite artifacts. There were no quartz denticulates identified within the assemblage (see Table 6.14). All of these artifacts possess less than $50 \%$ cortical coverage indicating that they are at an advanced stage of reduction. These tools were primarily produced on complete blanks indicating that they were either the intended initial product or the result of modification on an other wise exhausted blank. These tools are typically associated with domestic activities (see Table 6.15; Zilhão 1997a:157).

\begin{tabular}{|c|c|c|c|c|c|}
\hline \multicolumn{2}{|c|}{} & Chert & Quartz & Quartzite & Total \\
\hline $\begin{array}{c}\text { Typological } \\
\text { designation }\end{array}$ & Denticulate (75) & 4 & 0 & 1 & $\mathbf{5}$ \\
\hline \multicolumn{2}{|c|}{ Total } & $\mathbf{4}$ & $\mathbf{0}$ & $\mathbf{1}$ & \\
\hline
\end{tabular}

Table 6.15: Inventory of denticulate typology 
Notches

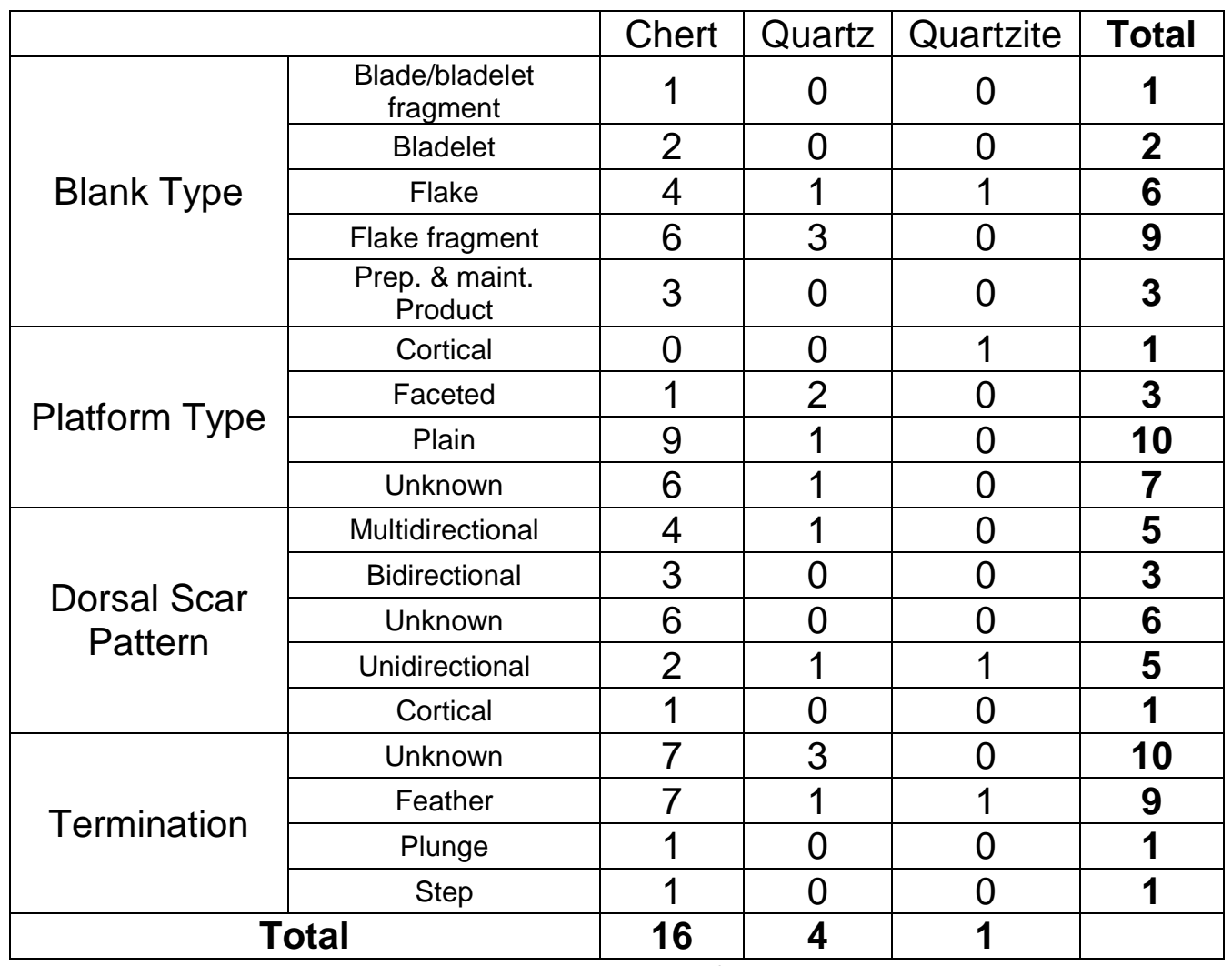

Table 6.16: Inventory of notches

The notches are $76.19 \%$ chert, $19.04 \%$ quartz, and $4.76 \%$ quartzite (see

Table 6.16$) .76 .19 \%$ were found to possess no cortex, meaning that the majority of their blanks were reduced when the core was in an advanced stage of reduction, but before being exhausted. This is corroborated by $47.61 \%$ of these tools being produced on fragments of blanks, indicating that these tools were modified from previously broken/exhausted blanks. These tools are associated with domestic activities (see Table 6.17; Zilhão 1997a:157).

\begin{tabular}{|c|c|c|c|c|c|}
\hline \multicolumn{2}{|c|}{} & Chert & Quartz & Quartzite & Total \\
\hline Typological designation & $\begin{array}{c}\text { Notch } \\
(74)\end{array}$ & 16 & 4 & 1 & $\mathbf{2 1}$ \\
\hline Total & & $\mathbf{1 6}$ & $\mathbf{4}$ & $\mathbf{1}$ & \\
\hline
\end{tabular}

Table 6.17: Inventory of notch typology 


\section{$\underline{\text { Perforators }}$}

\begin{tabular}{|c|c|c|c|c|c|}
\hline \multicolumn{2}{|c|}{} & Chert & Quartz & Quartzite & Total \\
\hline \multirow{2}{*}{ Blank Type } & $\begin{array}{c}\text { Blade/bladelet } \\
\text { fragment }\end{array}$ & 1 & 0 & 0 & $\mathbf{1}$ \\
\cline { 2 - 6 } & Flake & 0 & 1 & 0 & $\mathbf{1}$ \\
\hline \multirow{2}{*}{ Platform Type } & Cortical & 0 & 1 & 0 & $\mathbf{1}$ \\
\cline { 2 - 6 } & Faceted & 1 & 0 & 0 & $\mathbf{1}$ \\
\hline \multirow{2}{*}{$\begin{array}{c}\text { Dorsal Scar } \\
\text { Pattern }\end{array}$} & Bidirectional & 1 & 0 & 0 & $\mathbf{1}$ \\
\cline { 2 - 6 } Termination & Cortical & 0 & 1 & 0 & $\mathbf{1}$ \\
\cline { 2 - 6 } & Unknown & 0 & 1 & 0 & $\mathbf{1}$ \\
\cline { 2 - 6 } & Feather & 1 & 0 & 0 & $\mathbf{1}$ \\
\hline \multicolumn{2}{|c|}{ Total } & $\mathbf{1}$ & $\mathbf{1}$ & $\mathbf{0}$ & \\
\hline
\end{tabular}

Table 6.18: Inventory of perforators

The perforators are made from chert and quartz. They both possess less than $50 \%$ cortical coverage indicating that their blanks were produced when the core was in an advanced stage of reduction, but before being exhausted. These tools are associated with domestic activities (see Table 6.19; Zilhão 1997a:157).

\begin{tabular}{|c|c|c|c|c|c|}
\hline \multicolumn{2}{|c|}{} & Chert & Quartz & Quartzite & Total \\
\hline $\begin{array}{l}\text { Typological } \\
\text { designation }\end{array}$ & Perforator (73) & 1 & 1 & 0 & 2 \\
\hline \multicolumn{2}{|c|}{ Total } & 1 & 1 & 0 & \\
\hline
\end{tabular}

Table 6.19: Inventory of perforator typology 
$\underline{\text { Side Scrapers }}$

\begin{tabular}{|c|c|c|c|c|c|}
\hline \multicolumn{1}{|c|}{} & Chert & Quartz & Quartzite & Total \\
\hline \multirow{4}{*}{ Blank Type } & $\begin{array}{c}\text { Blade/bladelet } \\
\text { fragment }\end{array}$ & 1 & 0 & 0 & $\mathbf{1}$ \\
\cline { 2 - 6 } & Flake & 3 & 0 & 0 & $\mathbf{3}$ \\
\cline { 2 - 6 } & $\begin{array}{c}\text { Flake } \\
\text { fragment }\end{array}$ & 2 & 0 & 0 & $\mathbf{2}$ \\
\cline { 2 - 6 } & Burin spall & 1 & 0 & 0 & $\mathbf{1}$ \\
\hline \multirow{4}{*}{ Platform Type } & Cortical & 1 & 0 & 0 & $\mathbf{1}$ \\
\cline { 2 - 6 } & Unknown & 1 & 0 & 0 & $\mathbf{1}$ \\
\cline { 2 - 6 } & Plain & 1 & 0 & 0 & $\mathbf{1}$ \\
\cline { 2 - 6 } & Faceted & 3 & 0 & 0 & $\mathbf{3}$ \\
\hline \multirow{3}{*}{ Dorsal Scar } & Unidirectional & 3 & 0 & 0 & $\mathbf{3}$ \\
\cline { 2 - 6 } & Cortical & 1 & 0 & 0 & $\mathbf{1}$ \\
\cline { 2 - 6 } & Unknown & 3 & 0 & 0 & $\mathbf{3}$ \\
\hline \multirow{2}{*}{ Termination } & Unknown & 6 & 0 & 0 & $\mathbf{6}$ \\
\cline { 2 - 6 } & Feather & 1 & 0 & 0 & $\mathbf{1}$ \\
\hline \multicolumn{2}{|c|}{ Total } & $\mathbf{7}$ & $\mathbf{0}$ & $\mathbf{0}$ & \\
\hline
\end{tabular}

Table 6.20: Inventory of side scrapers

All of the side scrapers were produced from chert. $85.71 \%$ of these

artifacts possessed less than $50 \%$ cortex, indicating their blanks were produced when the core was in an advanced stage of reduction, but before being exhausted. These tools are associated with domestic activities (see Table 6.21; Zilhão 1997a:157).

\begin{tabular}{|c|c|c|c|c|c|}
\hline \multicolumn{2}{|c|}{} & Chert & Quartz & Quartzite & Total \\
\hline Typological designation & $\begin{array}{c}\text { Side Scraper } \\
(77)\end{array}$ & 7 & 0 & 0 & 7 \\
\hline \multicolumn{2}{|c|}{ Total } & 7 & 0 & 0 & \\
\hline
\end{tabular}




\section{End Scrapers}

Endscrapers are divided between thick and thin; thick can be associated with being cores to produce bladelets, often with twisted profiles, and thin being associated with domestic tasks (Zilhão 1997a:157).

\begin{tabular}{|c|c|c|c|c|c|}
\hline & & Chert & Quartz & Quartzite & Total \\
\hline \multirow{4}{*}{ Blank Type } & Bladelet & 2 & 0 & 0 & 2 \\
\hline & Flake & 3 & 0 & 0 & 3 \\
\hline & Flake fragment & 1 & 1 & 0 & 2 \\
\hline & $\begin{array}{l}\text { Prep. \& maint. } \\
\text { Product }\end{array}$ & 1 & 0 & 0 & 1 \\
\hline \multirow{3}{*}{ Platform Type } & Faceted & 2 & 0 & 0 & 2 \\
\hline & Unknown & 1 & 1 & 0 & 2 \\
\hline & Plain & 4 & 0 & 0 & 4 \\
\hline \multirow{5}{*}{$\begin{array}{c}\text { Dorsal Scar } \\
\text { Pattern }\end{array}$} & Unidirectional & 1 & 0 & 0 & 1 \\
\hline & Bidirectional & 3 & 0 & 0 & 3 \\
\hline & Cortical & 1 & 0 & 0 & 1 \\
\hline & Convergent & 1 & 0 & 0 & 1 \\
\hline & Unknown & 1 & 1 & 0 & 2 \\
\hline \multirow{3}{*}{ Termination } & Unknown & 4 & 1 & 0 & 5 \\
\hline & Feather & 2 & 0 & 0 & 2 \\
\hline & Hinge & 1 & 0 & 0 & 1 \\
\hline \multicolumn{2}{|c|}{ Total } & 7 & 1 & 0 & \\
\hline
\end{tabular}

Table 6.22: Inventory of thick endscrapers

The thick endscrapers are $87.5 \%$ chert and $12.5 \%$ quartz; none were found to be produced on quartzite (see Table 6.22). Thick endscrapers were found to be used as bladelet cores in the Portuguese Upper Paleolithic; this production results in bladelets with twisted profiles (Zilhão 1997; Almeida 2000). In the assemblage, we have 25 bladelets (chert =\#24, quartz =\#1) that possess twisted profiles that are indicative of being produced from utilizing thick endscrapers as cores. As there were no quartzite thick endscrapers, there were also no bladelets with twisted profiles in quartzite. This demonstrated that these tools were utilized in one of two potential manners: 1.) purely as cores for 
bladelets or 2.) as cores for bladelets and as domestic tools themselves (see Table 6.23; Zilhão 1997a:157). However, this would require further investigation through refitting and usewear analysis.

\begin{tabular}{|c|c|c|c|c|c|}
\hline \multicolumn{1}{|c|}{} & Chert & Quartz & Quartzite & Total \\
\hline \multirow{4}{*}{$\begin{array}{c}\text { Typological } \\
\text { designation }\end{array}$} & Scraper on blade (8) & 1 & 0 & 0 & $\mathbf{1}$ \\
\cline { 2 - 6 } & Carinated Endscraper (11) & 3 & 0 & 0 & $\mathbf{3}$ \\
\cline { 2 - 6 } & $\begin{array}{c}\text { Atypical carinated } \\
\text { endscraper (12) }\end{array}$ & 1 & 0 & 0 & $\mathbf{1}$ \\
\cline { 2 - 6 } & Thick scraper (13) & 1 & 1 & 0 & $\mathbf{2}$ \\
\cline { 2 - 6 } & Nucleiform scraper (15) & 1 & 0 & 0 & $\mathbf{1}$ \\
\hline Total & & $\mathbf{7}$ & $\mathbf{1}$ & $\mathbf{0}$ & \\
\hline
\end{tabular}

Table 6.23: Inventory of thick endscraper typologies

\begin{tabular}{|c|c|c|c|c|c|}
\hline & & Chert & Quartz & Quartzite & Total \\
\hline \multirow{4}{*}{ Blank Type } & Bladelet & 4 & 0 & 0 & 4 \\
\hline & $\begin{array}{c}\text { Blade/bladelet } \\
\text { fragment }\end{array}$ & 3 & 0 & 0 & 3 \\
\hline & Flake & 4 & 0 & 0 & 4 \\
\hline & $\begin{array}{c}\text { Flake } \\
\text { fragment }\end{array}$ & 3 & 0 & 0 & 3 \\
\hline \multirow{3}{*}{ Platform Type } & Faceted & 3 & 0 & 0 & 3 \\
\hline & Unknown & 9 & 0 & 0 & 9 \\
\hline & Plain & 2 & 0 & 0 & 2 \\
\hline \multirow{3}{*}{$\begin{array}{l}\text { Dorsal Scar } \\
\text { Pattern }\end{array}$} & Unidirectional & 6 & 0 & 0 & 6 \\
\hline & Bidirectional & 1 & 0 & 0 & 1 \\
\hline & Unknown & 7 & 0 & 0 & 7 \\
\hline Termination & Unknown & 14 & 0 & 0 & 14 \\
\hline \multicolumn{2}{|c|}{ Tot } & 14 & 0 & 0 & \\
\hline
\end{tabular}

Table 6.24: Inventory of thin endscrapers

All of the thin endscrapers are produced from chert. $78.57 \%$ possess no cortex, indicating that they are at an advanced stage of reduction; this is further corroborated by $42.85 \%$ of these being represented on fragments of blanks indicating that these tools were produced from previously broken/exhausted 
blanks. These tools are associated with domestic activities (see Table 6.25; Zilhão 1997a:157).

\begin{tabular}{|c|c|c|c|c|c|}
\hline & Chert & Quartz & Quartzite & Total \\
\hline \multirow{4}{*}{$\begin{array}{c}\text { Typological } \\
\text { designation }\end{array}$} & $\begin{array}{c}\text { Simple scraper on end of } \\
\text { bladelet (1a) }\end{array}$ & 4 & 0 & 0 & $\mathbf{4}$ \\
\cline { 2 - 6 } & $\begin{array}{c}\text { Simple scraper on end of } \\
\text { flake (1b) }\end{array}$ & 1 & 0 & 0 & $\mathbf{1}$ \\
\cline { 2 - 6 } & $\begin{array}{c}\text { Atypical scraper on end of } \\
\text { flake (2b) }\end{array}$ & 4 & 0 & 0 & $\mathbf{4}$ \\
\cline { 2 - 6 } & $\begin{array}{c}\text { Scraper on end of retouched } \\
\text { bladelet (5a) }\end{array}$ & 2 & 0 & 0 & $\mathbf{2}$ \\
\cline { 2 - 6 } & Scraper on flake (8) & 1 & 0 & 0 & $\mathbf{1}$ \\
\hline & Unguiforme scraper (10) & 2 & 0 & 0 & $\mathbf{2}$ \\
\hline
\end{tabular}

Table 6.25: Inventory of thin endscraper typologies

Truncations

\begin{tabular}{|c|c|c|c|c|c|}
\hline & Chert & Quartz & Quartzite & Total \\
\hline \multirow{4}{*}{ Blank Type } & Bladelet & 5 & 0 & 0 & 5 \\
\hline & $\begin{array}{c}\text { Blade/bladelet } \\
\text { fragment }\end{array}$ & 3 & 0 & 0 & 3 \\
\hline & Flake & 3 & 0 & 1 & 3 \\
\hline & Flake fragment & 0 & 1 & 0 & 1 \\
\hline \multirow{4}{*}{$\begin{array}{l}\text { Platform } \\
\text { Type }\end{array}$} & Faceted & 5 & 0 & 0 & 5 \\
\hline & Unknown & 2 & 0 & 0 & 2 \\
\hline & Indeterminate & 2 & 1 & 0 & 3 \\
\hline & Plain & 2 & 0 & 1 & 3 \\
\hline \multirow{4}{*}{$\begin{array}{c}\text { Dorsal Scar } \\
\text { Pattern }\end{array}$} & Unidirectional & 5 & 0 & 0 & 5 \\
\hline & Cortical & 0 & 0 & 1 & 1 \\
\hline & Bidirectional & 4 & 0 & 0 & 4 \\
\hline & Unknown & 2 & 1 & 0 & 3 \\
\hline Termination & Unknown & 11 & 1 & 1 & 13 \\
\hline \multicolumn{2}{|r|}{ Total } & 11 & 1 & 1 & \\
\hline
\end{tabular}

Table 6.26: Inventory of truncations

The truncations are $84.61 \%$ chert, $7.69 \%$ quartz, and $7.69 \%$ quartzite (see Table 6.26). $92.30 \%$ were found to possess no cortex, thus the majority of these artifacts were their blanks were produced when the core was in an advanced 
stage of reduction, but before being exhausted. $30.76 \%$ of these tools are produced on fragments of blanks, indicating that these tools were modified from previously broken/exhausted blanks. These tools are associated with hunting activities (see Table 6.27; Zilhão 1997a:157).

\begin{tabular}{|c|c|c|c|c|c|}
\hline & Chert & Quartz & Quartzite & Total \\
\hline \multirow{4}{*}{$\begin{array}{c}\text { Typological } \\
\text { designation }\end{array}$} & \begin{tabular}{c} 
Truncation on bladelet (60) \\
\cline { 2 - 6 }
\end{tabular} & 6 & 0 & 0 & $\mathbf{6}$ \\
\cline { 2 - 6 } & $\begin{array}{c}\text { Oblique truncation on bladelet } \\
(61)\end{array}$ & 4 & 0 & 0 & $\mathbf{4}$ \\
\cline { 2 - 6 } & $\begin{array}{l}\text { Bi-truncated bladelet (64a) } \\
\text { Concave truncation on } \\
\text { bladelet or flake (62) } \\
\text { Total }\end{array}$ & 1 & 0 & 0 & $\mathbf{1}$ \\
\hline \multicolumn{2}{|c|}{ Tala } & $\mathbf{1 1}$ & $\mathbf{1}$ & $\mathbf{1}$ & $\mathbf{2}$ \\
\hline
\end{tabular}

Table 6.27: Inventory of truncation typologies 


\section{CHAPTER VII:}

DISCUSSION, CONCLUSIONS, AND FUTURE RESEARCH OPPORTUNITIES

\section{$\underline{\text { Analysis Interpretation }}$}

This analysis of the lithic assemblage from Layer F/G at Lapa do Picareiro presented in the previous chapter will be utilized to interpret raw material economy, lithic economy, and site function during the late Magdalenian. Lapa do Picareiro's lithic data will then be compared with other regionally contemporaneous collections to determine similarities and differences between the sites.

Raw Material and Lithic Economy

\begin{tabular}{|c|c|c|c|}
\hline & $\begin{array}{c}\text { Number of } \\
\text { artifacts }\end{array}$ & Weight (g) & $\begin{array}{c}\text { \% of } \\
\text { assemblage }\end{array}$ \\
\hline Chert & 2,126 & $2,625.97$ & 64.81 \\
\hline Quartz & 638 & 782.03 & 19.45 \\
\hline Quartzite & 503 & $13,664.74$ & 15.33 \\
\hline Miscellaneous & 13 & 987.26 & 0.39 \\
\hline Total & $\mathbf{3 , 2 8 0}$ & $\mathbf{1 8 , 0 6 0 g}$ & $\mathbf{9 9 . 9 8 \%}$ \\
\hline
\end{tabular}

Table 7.1: Assemblage represented by number, weight, and percent representation

The Layer F/G assemblage weighs 18,060g ( $\approx 39.82 \mathrm{lbs}$.); excluding chips (See Chapter IV, this volume). Of that, chert makes up 2,625.97g (5.79 lbs.) representing $14.54 \%$ of the assemblage; quartz represents $782.03 \mathrm{~g}(\approx 1.72 \mathrm{lbs}$.) or $4.33 \%$ of the assemblage; quartzite represents $13,664.74 \mathrm{~g}(\approx 30.13 \mathrm{lbs}$.) or $75.66 \%$ of the assemblage; While the remainder of the raw materials make up 
$987.26 \mathrm{~g}(\approx 2.18 \mathrm{lbs}$.$) or 5.46 \%$ of the assemblage and is composed of limestone $(\# 7=667 \mathrm{~g})$, sandstone $(\# 1=287.50 \mathrm{~g})$, schist $(\# 1=27.70 \mathrm{~g})$, basalt $(\# 1=3.70 \mathrm{~g})$, and rock crystal $(\# 3=1.36 \mathrm{~g})$. Chert far out numbers quartz and quartzite in terms of number of artifacts, however quartzite far out weights chert, quartz, and the miscellaneous raw materials (See Figure 7.1 and Figure 7.2).

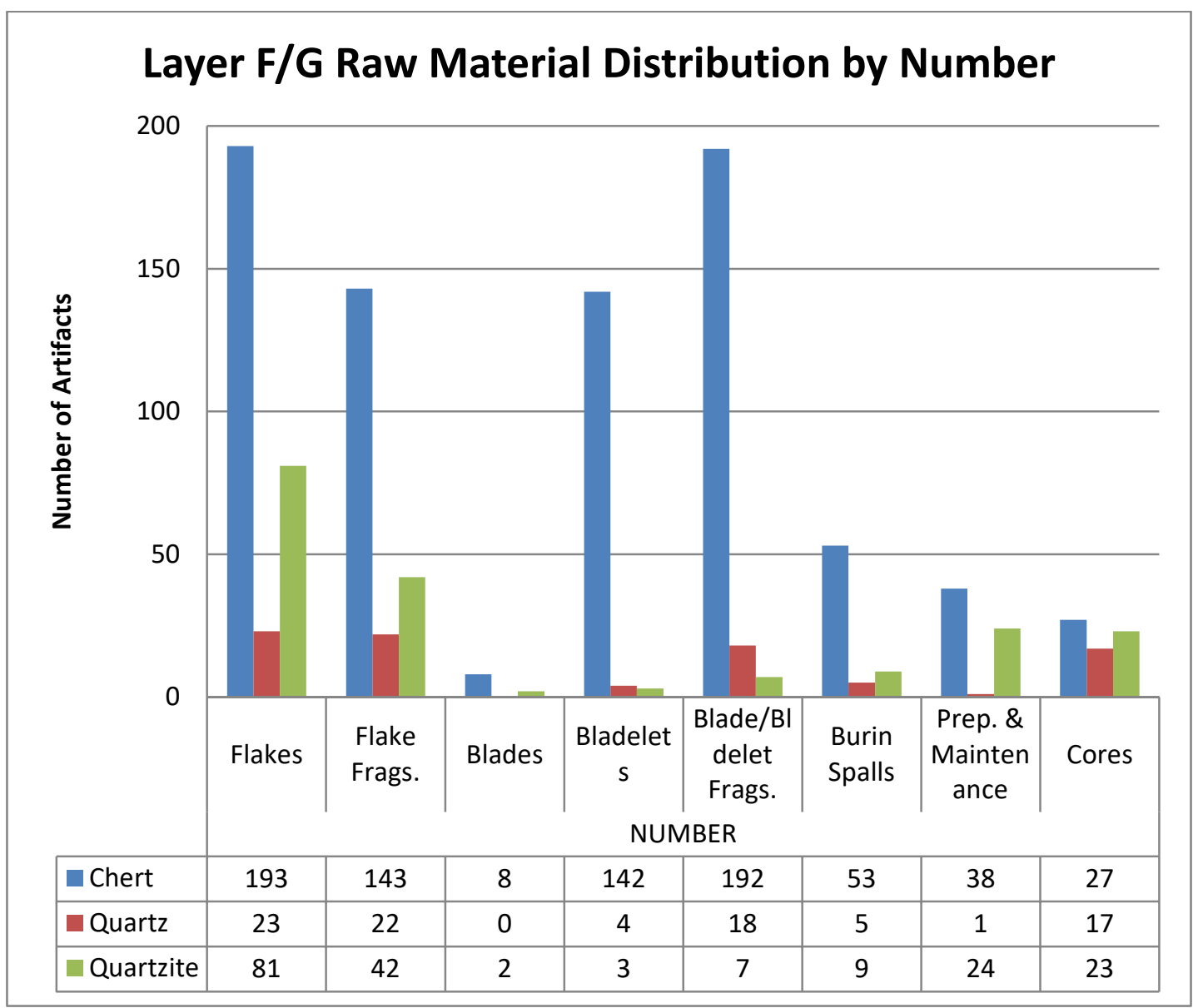

Figure 7.1: Raw material distribution by number less chips 


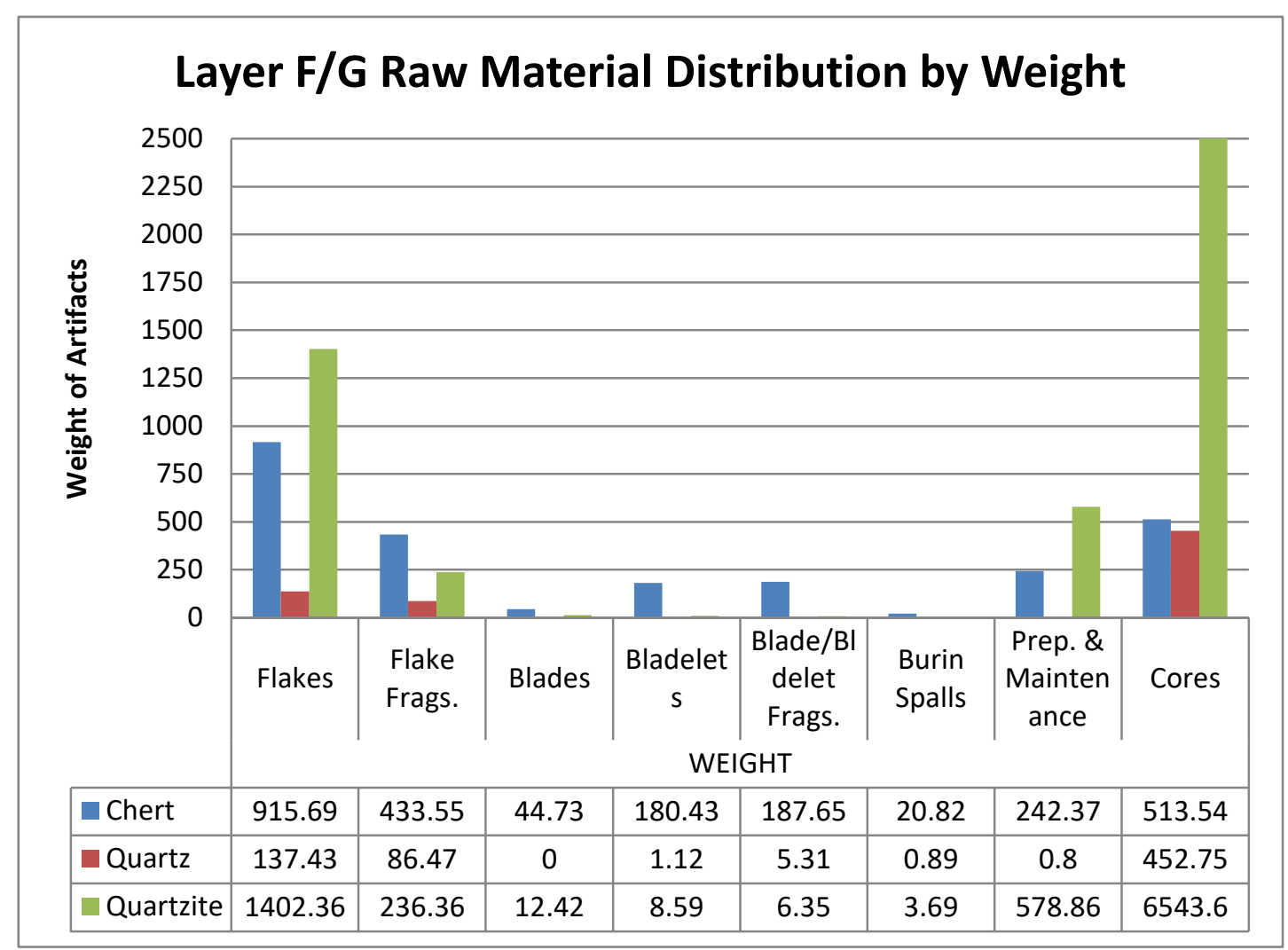

Figure 7.2: Raw material distribution by weight less chips

\begin{tabular}{|c|c|c|}
\hline & \# of Artifacts & \# of retouched tools \\
\hline Chert & 825 & 189 \\
\hline Quartz & 103 & 19 \\
\hline Quartzite & 245 & 3 \\
\hline Total & $\mathbf{1 1 8 4}$ & $\mathbf{2 1 1}$ \\
\hline
\end{tabular}

Table 7.2: Raw material representation by number of artifacts (less chips) and number of retouched tools

These raw materials were brought to the site with preliminary testing and/or preparation, as $92.98 \%(\# 1,101)$ of the assemblage has less than $50 \%$ cortex present. Further corroborating this is the size of the artifacts recovered from the site. The assemblage (less chips) consists of small sized artifacts, $91.65 \%$ smaller than $40 \mathrm{~mm}$ long, and $18.9 \%$ less than $20 \mathrm{~mm}$ long; the largest artifact (not including cores) is a quartzite flake measuring $91.34 \mathrm{~mm}$ long. Preliminary preparation of the cores before being brought to Picareiro could have 
played a role in the size of the artifacts being produced. Taking the data gathered from the previous analysis of Picareiro's lithic assemblage (see Chapter IV), it is agreed that core preparation (except in the case of quartzite) occurred prior to the cores being transported to the site (Bicho et al. 2006; Pereira 2010; Mendonça 2011). The role of chips, due to their size and quantity, are interpreted as resulting from tool resharpening and retouch (Bicho et al. 2006; Mendonça 2011); however, the analysis presented here besides confirming this it also points for the possibility of an intentional production of very small implements with cutting edges to be used as barbs, thus the need for further investigation.

Once at the site, the raw materials were subjected to different intensities of reduction. Table 7.2 show the number of artifacts for each raw material (less chips) and the number of those which are retouched. From this, $22.9 \%$ chert, $18.44 \%$ quartz, and $1.22 \%$ quartzite artifacts were retouched. The traditional functional attribution for each retouch tool indicates that, from complete artifacts to fragments, the quartzite retouched artifacts are primarily domestic tools, the quartz ones are majority fragments of hunting implements, and those on chert are hunting implements and domestic tools.

The unretouched blanks can be interpreted primarily in three ways: 1.) as blanks produced for use as tools; 2.) as blanks produced with the intent to retouch and use as tools; 3 .) as blanks produced as debris from another tools production. These conjectures however would need further investigation through refitting and use wear analysis. 


\section{Discerning Site Function from the Assemblage Analysis}

One of the primary objectives of this thesis is to identify site function and patterns in human behavior during the Late Magdalenian occupation of Layer F/G at Lapa do Picareiro. Zilhão (1997a: 156-157,161; 167) provides several indices designed to evaluate the contents of a lithic assemblage to determine site function based upon identified site types in the region. Zilhão states that "the various archaeological contexts currently known in the [Portuguese] Paleolithic can be grouped into five categories" (1997a: 167). These five categories, or groups, are meant to assist in the identification of site function based upon variation within a sites lithic assemblage (1997a: 164-165, 168) (see Appendix III, this volume for detailed quantitative analysis).

The Production Index (PI) established by Zilhão (1997a:157) is meant to discern the proportion of domestic tools being produced at the site. This is calculated by taking the number of cores and comparing it to the number of retouched tools considered to be for domestic use (this is not including burins, thick endscrapers, or functionally ambiguous typological groups such as composites and truncations, nor hunting implements). For the Layer F/G assemblage, this ratio is 68 cores: 49 domestic tools. This ration demonstrates that while there are a significant amount of cores, there is also a significant amount of domestic tools (nearly $1 / 4$ the retouched tool assemblage). Thus, the site has more than just logistical activities being carried out.

The Barb Production Index (CPI) (Zilhão 1997a: 161) is a means to discern if the assemblage possesses reduction geared towards production of 
logistical tools. This is done by taking the percentage of total retouched tools that are also identified as being bladelet cores (i.e. burins and thick endscrapers). There are 57 of these artifacts identified, and when compared to the total number of retouched tools (211), they represent $27.01 \%$ of the retouched tool assemblage. However, backed bladelets are removed from the equation, these core types representing $45.96 \%$ of the retouched tool assemblage. This index demonstrates the focus on bladelet production at Picareiro.

The Export Indices (IE) that Zilhão (1997a) established are utilized to help discern what was being produced and then transported from the site. IE1 is calculated by establishing a ratio between the number of prismatic cores and the minimum number of bladelets (including complete and proximal fragments of bladelets). For Layer F/G, this ratio is 19:225. The high ratio of bladelets to the small ratio of cores is indicative of intensive bladelet production. IE2 is the percentage of blades with no cortex and a trapezoidal cross section present in the retouched tool assemblage. For Layer F/G this is $1.89 \%$. This is representative of a very low incidence of blades at the site, thus bladelets were the intended product, the cores were of small volume resulting in bladelets, or the blades were exported from the site. The cores, as discussed in Chapter VI, were brought to the site in a stage of preliminary reduction, thus lending to the possibility that core size could have played a role, but since the other contemporaneous sites also possess such a low representation of blades, it could be inferred that it was an intended (cultural) choice to produce bladelets instead of blades. 
The Logistical Activity Indices (IAL) looks at the ratio of retouched tools associated with hunting (backed bladelets) to those raw materials associated with domestic activities (not including composites and truncations due to their ambiguous use, or burins and thick endscrapers due to their use as bladelet cores). Of the two indices, ILA2 is utilized because it applies to the typology of the Magdalenian. For Layer F/G this ratio is 87 backed bladelets: 49 domestic tools. Despite being of relatively high value, this ratio demonstrates that there is not a monopoly one way or another towards production being logistically or residentially focused.

How will applying these indices allude to as to the function of Lapa do Picareiro during the late Magdalenian? The Indices produce a means by which to take the data that was just produced and then equate them to a certain site type. As stated previously, Zilhão (1997a: 164-165, 168) established five identifiable site types in the Portuguese Upper Paleolithic; which are: Group 1: Quarries, Group 2: Residential camps, Group 3: Temporary hunting camps, Group 4: Cache, and Group 5: Episodic specialized hunting camps. After evaluating the requirements for attributing a site to one of the groups, it was determined that Lapa do Picareiro fits the attributes of Group 3: Temporary hunting camp and Group 5: Episodic specialized hunting camp.

Group 3 is defined as being a temporary hunting camp, with both logistical and domestic tools present. The raw materials utilized to produce the majority of the retouched tools would have been brought to the site, while those of largely domestic nature would have been procured from relatively local raw materials 
(quartz and quartzite). This group is differentiated from Group 2, residential/base camps, by possessing a high value in the Logistical Activities Index (IAL2; see above).

Group 5 is defined as having many of the same characteristics as Group 3 , however the tools attributed to hunting activities are not predominantly made from imported raw materials (chert) but also from locally available raw materials (quartz and quartzite). Group 5 also possesses a characteristic often assigned to Group 4, that being a high CPI index. Which, as stated above, Lapa do Picareiro possesses a relatively high CPI percentage.

So what does this mean as far as site function? Following these indexes and groups that are traditionally considered in the paleoethnographic of the Portuguese Paleolithic, it means that Lapa do Picareiro seems to have been utilized during the late Magdalenian as a temporary hunting camp, but also for specialized hunting expeditions. They could be one in the same, or they could represent different events. The tools recovered from the assemblage are indicative of hunting and processing of game animals. The domestic tools are those traditionally associated with animal processing. When we look at the faunal data from Lapa do Picareiro (Haws n.d.; see Table 3.1), it is evident that the primary game being hunted were red deer (Cervus elaphus), wild boar (Sus scrofa), and rabbit (Oryctolagus cuniculus). Further investigation and analysis of the distribution of the lithic assemblage, faunal assemblage, and features identified within the site would provide a unique insight into whether there is any distribution synchrony. 
Almeida (2004) hypothesizes that Lapa dos Coelhos and Lapa do Picareiro could potentially be sites occupied by individuals associated with the same nomadic group. The climatic changes that occurred during the YD and the resulting fluctuation in animal migrations across the landscape could have potentially resulted in the oscillation between the sites being habituated (Foraging Theory). However, to establish this hypothesis, further research beyond the scope of this Master's thesis would need to be done.

\section{Regional Site Comparisons}

There has been an influx of new information over the past several years, and it has led to a better understanding of hunter-gatherer raw material use and lithic technological adaptation during the latter half of the Upper Paleolithic in the Portuguese Estremadura (Gameiro 2012, Pereira 2010, Bicho 2000). There are now 12 sites with layers radiometrically dated to the Magdalenian (roughly 20 to 10 ka cal BP). Most of these dates were obtained from the sites of Cabeço do Porto Marinho (CPM) (Marks et al. 1994), Lapa do Picareiro (Bicho et al. 2000; See Appendix I this volume), Lapa do Suão (Zilhão 1997a; Haws 2003), and Lapa dos Coelhos (Almeida et al. 2004); All of which have had at least preliminary analysis of their lithic materials dating to this period analyzed. Now with the data acquired from the analysis of the late Magdalenian layer of $F / G$ from Lapa do Picareiro, it too can be introduced into the discussion about regional human behavior and ecodynamics at the end of the Pleistocene. This can be done by comparing assemblages that are contemporaneous with one another. In the case of Estremadura, the majority of the data on Magdalenian 
lithic technology is derived from CPM and Lapa dos Coelhos (Zilhão 1997a, Bicho 2000). Thus, these two sites make for good comparative collections with Picareiro because they possess similar occupational time scales, CPM and Coelhos have both under gone thorough analysis and thus have been well situated within the chronologically defined Magdalenian in central Portugal, and they are all in located within the same region (See Figures 7.3, 7.4, and 7.5).

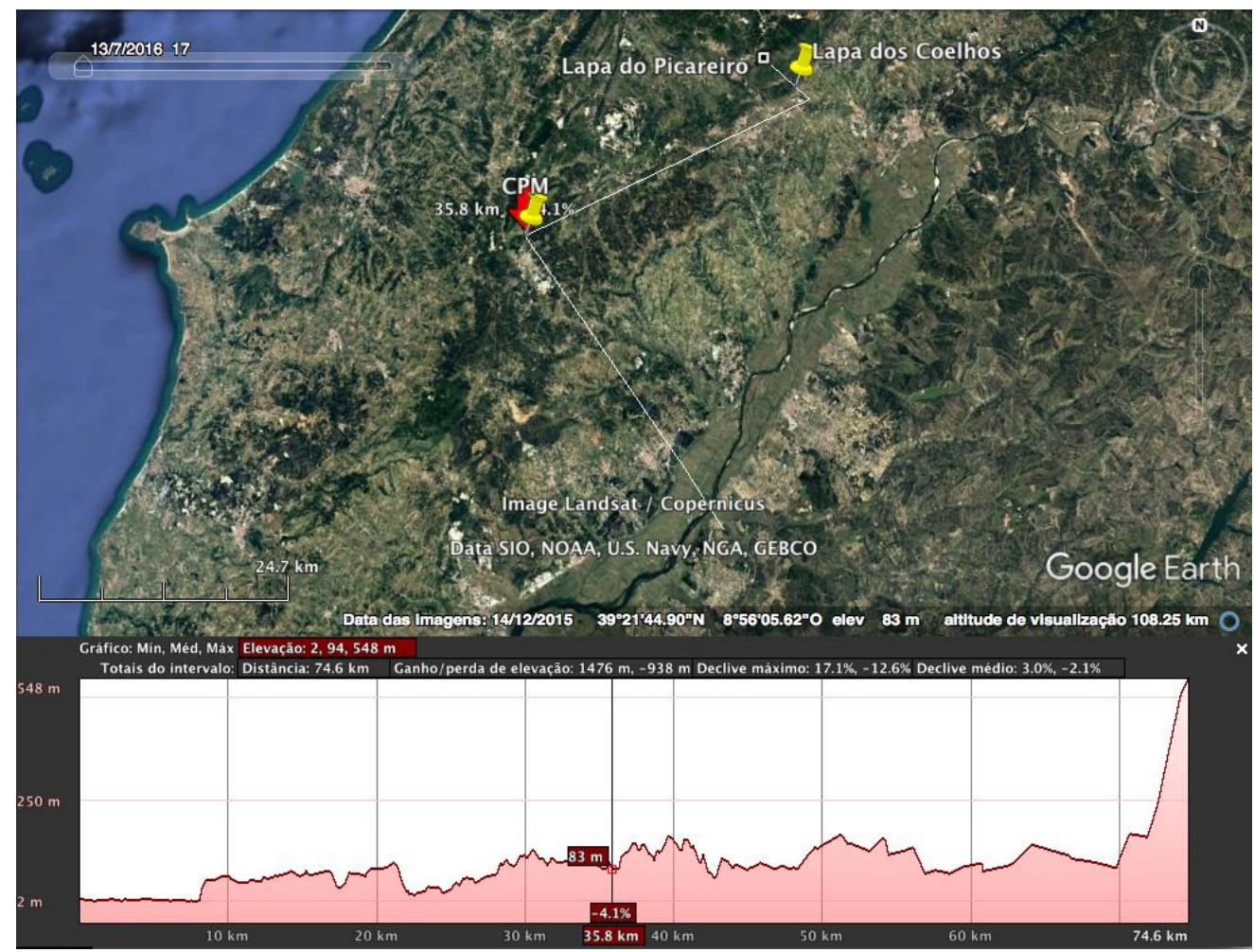

Figure 7.3: Location of CPM in relation to Coelhos and Picareiro. Elevation indicated in bottom of image. 


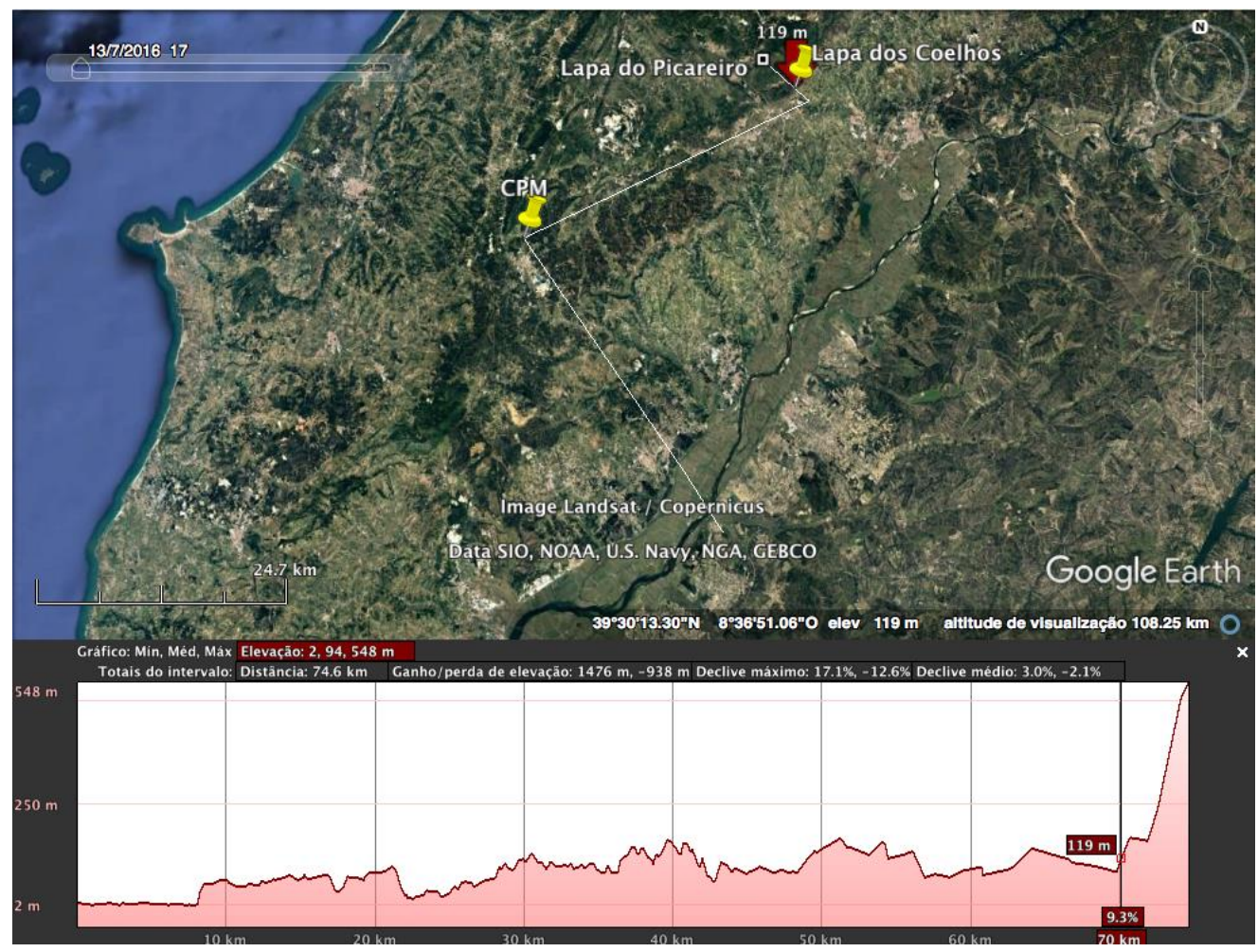

Figure 7.4: Location of Coelhos in relation to CPM and Picareiro. Elevation indicated in bottom of image.

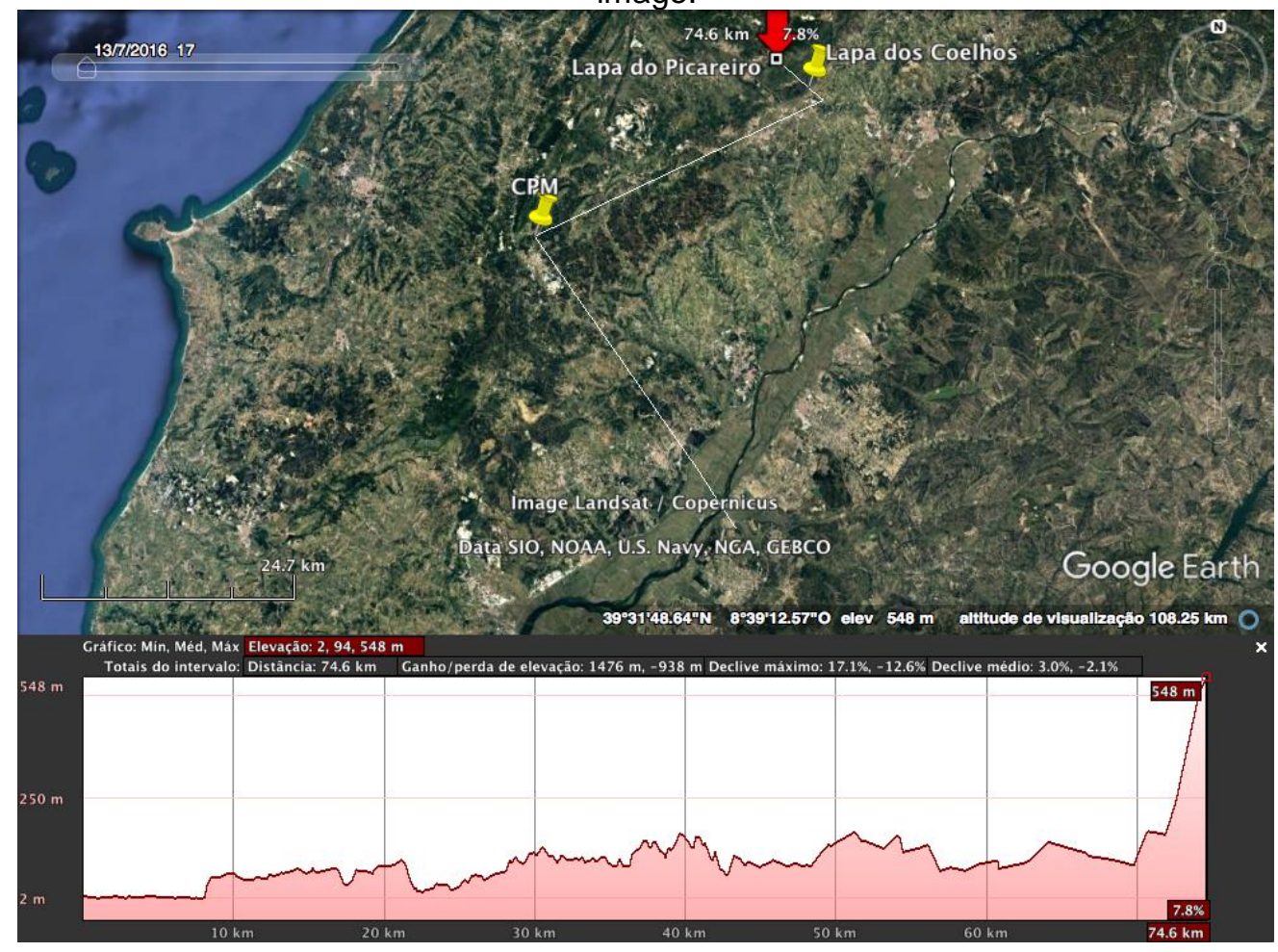

Figure 7.5: Location of Picareiro in relation to Coelhos and CPM. Elevation indicated in bottom of image. 
Figure 7.6 and Table 7.6 provide a general comparison of blank type, core, and retouched tool representations from each of the sites. Looking at the ratios displayed in Table 7.6 several trends can be identified. For example, there was very little emphasis on blade production at all of the sites, which is typical in the Portuguese Magdalenian. Another example is that Picareiro and Coelhos possess very similar bladelet to retouched tool ratios, whereas CPM possesses far more retouched tools than bladelets indicated by the same bladelet to retouched tool ratio.

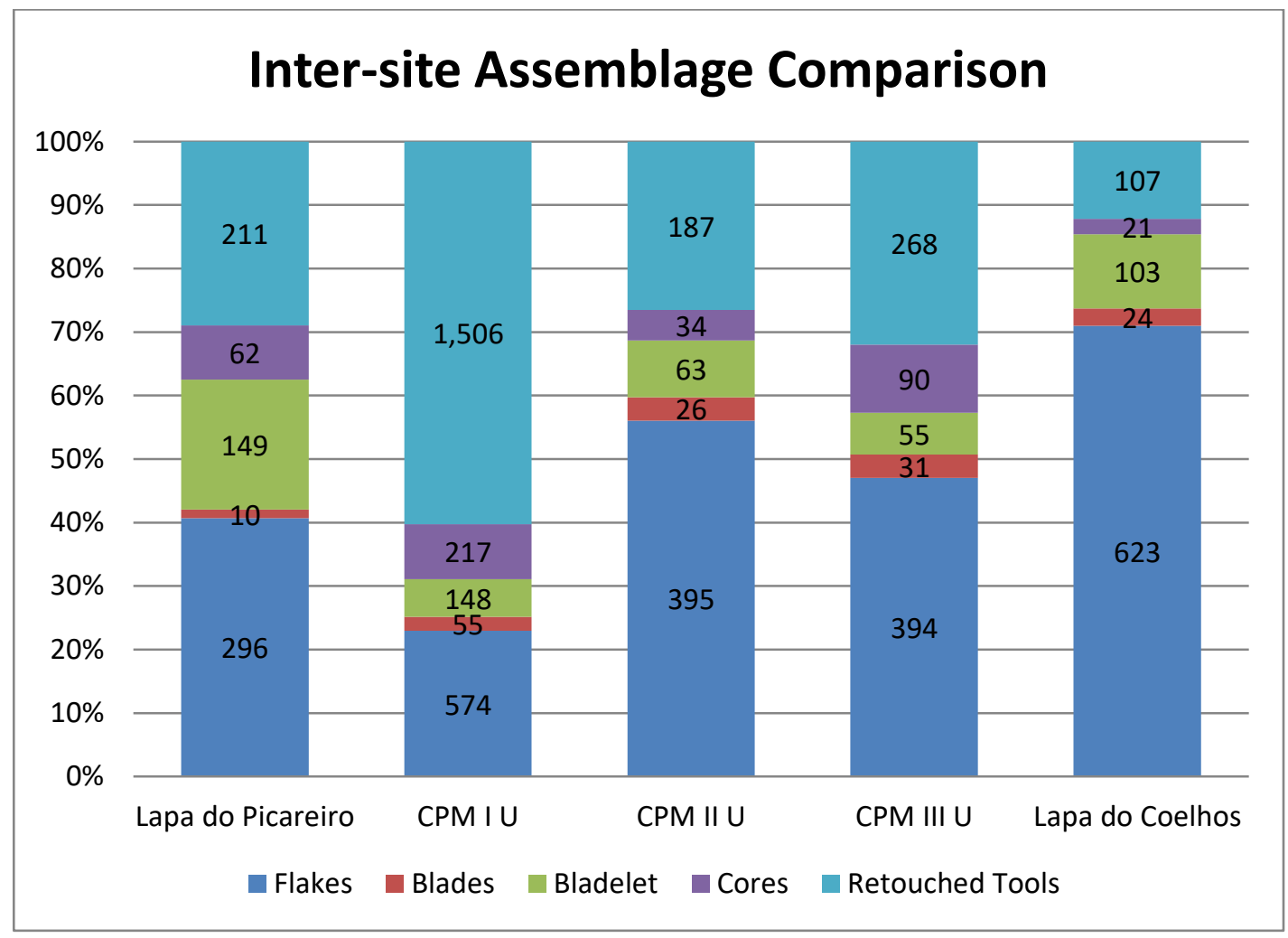

Figure 7.6: Inter-site comparison between Lapa do Picareiro, Cabeço de Porto Marinho (CPM) I Upper, CPM II Upper, and Lapa dos Coelhos (Zilhão 1997b; Bicho 1992; Almeida 2004) 


\begin{tabular}{|c|c|c|c|c|c|}
\hline Ratios & Picareiro & CPM I & CMP II & CPM III & Coelhos \\
\hline Bladelet: Retouched Tools & 0.70 & 0.09 & 0.33 & 0.20 & 0.96 \\
\hline Flake: Retouched Tools & 1.40 & 0.38 & 2.11 & 1.40 & 5.82 \\
\hline Blades: Retouched Tools & 0.05 & 0.04 & 0.13 & 0.12 & 0.22 \\
\hline $\begin{array}{c}\text { Bladelet+Blades+Flakes: Retouched } \\
\text { Tools }\end{array}$ & 2.16 & 0.51 & 2.58 & 1.79 & 7.00 \\
\hline Bladelet:Flake & 0.50 & 0.26 & 0.16 & 0.13 & 0.17 \\
\hline $\begin{array}{c}\text { Bladelet+Blades+Flakes+Retouched } \\
\text { Tools: Cores }\end{array}$ & 10.74 & 10.52 & 19.74 & 8.31 & 40.81 \\
\hline
\end{tabular}

Table 7.6: Inter-site comparison ratios.

Differential representation of artifacts, such as that shown in these diagrams, is ultimately conducive to discerning what a site was utilized for. Utilizing Zilhão's (1997a) definition of site types, CPM is representative of residential base camp, while Picareiro and Coelhos are hunting encampments. Thus, seeing the contrast in artifact type representation is interesting in that it highlights the differences in site types or function. For example, the large quantity of retouched tools and lower representation of bladelets at CPM are characteristic in this region and during this time period of residential sites, while the high occurrence of bladelets and lower representation of retouched tools found at Picareiro and Coelhos is similarly indicative to hunting camps (Zilhão 1997a). An in depth morphological and typological comparison of the blank types and retouched tools present at each site needs to be done to provide a complete picture of the variations in sites. From this general comparison however, it is still possible to identify an apparent trend in site function using artifact types. It is, after all, these subtle variations in lithic economy that can be the defining trait in discerning one site type from another. 


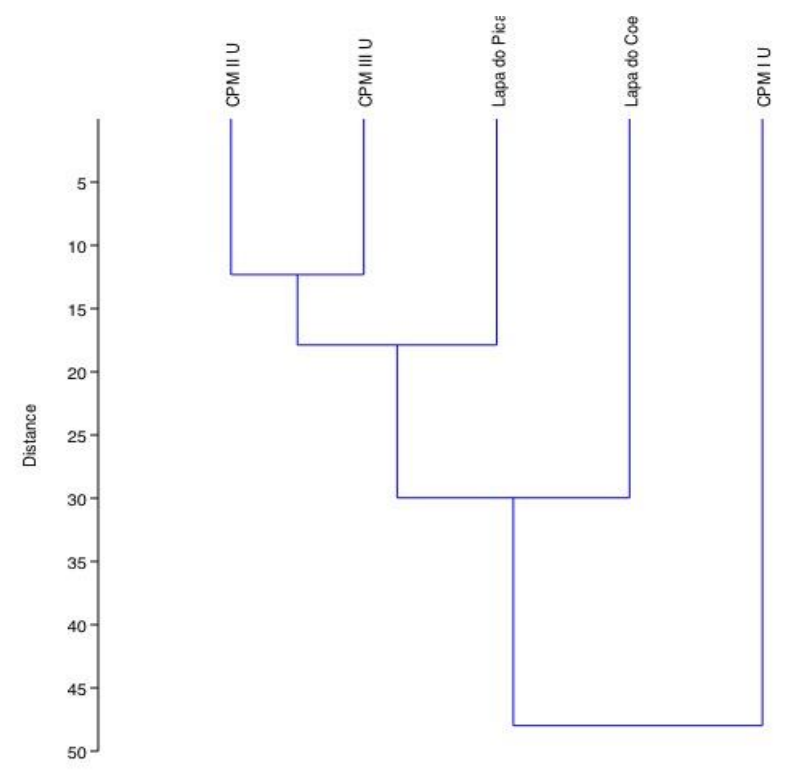

Figure 7.7: Cluster analysis of similarities between sites based upon blank type, core, and retouched tool representation at each site

Figure 7.7 is a cluster analysis for these sites based upon representative quantities of blank types, core presence, and retouched tool presence at each site; they do not represent specific tool or core types. As it has been shown, these sites possess several differences, while also sharing apparent similarities. CPM IU, CPM IIU, CPM IIIU, and Coelhos' assemblages possess similarities to Picareiro's Late Magdalenian assemblage in terms of raw material representation, use, and reduction. All of these sites possess chert, quartz, and quartzite as their primary raw materials selected and they are similar in that they all exercised preferential raw material reduction, for example, quartzite was the least represented in all five sites in the retouched tool assemblages (Zilhão 1997a, Bicho 2000; Marks et al. 1994). With that in mind and looking at Figure 7.7, it offers a visual representation that Lapa do Picareiro's Late Magdalenian lithic assemblage fits in with other regionally contemporaneous sites when considering just numeric quantities alone. 
It is important however to keep in mind that location could have also played a role in site function (See Images 7.1, 7.2, and 7.3). CPM is located on a terrace the possesses ample access to high quality raw material gravels sitting at only $83 \mathrm{~m}$ above sea level; Coelhos is located on the Eastern face of the Sierra d'Aire mountain range, at $119 \mathrm{~m}$ above sea level, with the nearby Tagus river providing the site with access to water, aquatic species, and transported raw material cobbles; Then there is Picareiro, towering at $570 \mathrm{~m}$ above sea level on the Western face of the Sierra d'Aire mountains. These sites are all located in different areas possessing different elevations and access to resources, thus site location could have played a role in site function. As previously stated however, a more comprehensive comparison and in depth analysis of these assemblages would need to occur to better understand these variations in site types.

Another site that would be interesting to add to this comparative analysis would be Lapa do Suão. The site is regionally contemporaneous to the others and possesses similar depositional chronology. Unfortunately however, the data recovery methods employed resulted in the production of data sets that are difficult to compare with such a specific time range as is being utilized in this analysis (i.e. Late Magdalenian). An in depth analysis of the assemblage done by Cláudia Manso (2015) could potentially be utilized for future data comparison encompassing a wider time frame or in bulk analysis.

\section{$\underline{\text { Conclusion and Future Research Opportunities }}$}

Much work is still left to be done to further evaluate Picareiro's role during the Late Magdalenian, not only within its own assemblage, but within the 
region. The Layer F/G assemblage should undergo further investigation in some of the following manners: 1.) Analysis of the core negatives and those artifacts classified as chips; were these chips produced intentionally or were they just debris as a product of knapping? 2.) Investigation of the role of cores for bladelets (i.e. burins, thick endscrapers); were these simply domestic tools? Were they cores for bladelets? Or were they tools and cores for bladelets? Use wear analysis and refitting could potentially shed some light on this. 3.) Analysis of burin spalls to determine if their production was the result of producing a useable burin or for the use of the burin spalls as hunting tools; Use wear analysis and investigation as to the presence or absence of impact fractures would be needed. 4.) Investigation into where the quartzite burin spalls came from; where are the associated burins? 5.) Analysis of the backed bladelets, including those that are fragmentary, to establish use; were they cutting tools or were they inset as barb hunting tips? Use wear analysis and investigation as to the presence or absence of impact fractures would be needed. 6.) An in depth analysis of the role of unretouched blanks. Were these used as tools without further modification or were they produced with intent to eventually retouch into specific tools? This would require use wear analysis. 7.) Analyzing the complete Magdalenian sequence from Picareiro; the analysis presented in this thesis only represents one layer associated within the Magdalenian occupations of the cave, could analysis of the other layers influence the interpretation of site function during the Magdalenian? Would it affect how the site is perceived when compared with the other regionally contemporaneous sites? 8.) Identification and 
attribution of raw materials to specific sources to allow for a better understanding of material transport and provide more information about the amount of cortical presence identified on the materials at the site (i.e. were they getting the raw material from a quarry or gravels). 9.) Refitting of artifacts would be pertinent to understanding spatial distribution within the cave which would allow for paleoethnographic interpretations of the artifact, fauna, and charcoal concentrations. Refitting would also be pertinent to understanding the reduction sequence at the cave. Pereira (2010) demonstrated that refittings exist in quartzite within the assemblage, thus it can be expected to find refits in other raw materials as well. Refittings can also provide insight into the importation and exportation of blanks and tools by potentially showing the presence or absence of some specific elements.

This thesis demonstrates the value of utilizing a lithic analytic approach to answering important questions about prehistoric cultural ecology. Having presented an in-depth analysis of the lithic materials recovered from the Late Magdalenian occupation Layer F/G has allowed for information pertaining to raw material use, reduction phase representation, and identification of specific typologies indicative of site functionality to be discerned and utilized to contextualize Lapa do Picareiro within the broader context of the Late Magdalenian in Estremadura. The data presented here allows for the introduction of the Late Magdalenian lithic assemblage from Layer F/G at Lapa do Picareiro to enter the regional discussion about human behavior and ecodynamics during the end of the Pleistocene. 


\section{REFERENCES}

Almeida, Francisco

2000 The Terminal Gravettian of Portuguese Estremadura. Dallas: Southern Methodist University.

Almeida, Francisco, Cristina Gameiro, and João Zilhão

2002 The Artifact Assemblages. In Portrait of the artist as a child. The Gravettian human skeleton from the Abrigo do Lagar Velho and its archeological context edited by J. Zilhão and E. Trinkaus, pp. 202-219. Instituto Português de Arqueologia: Lisboa.

Almeida, Francisco, Diego E. Angelucci , Cristina Gameiro, José Correia, and Teresa Pereira

2004 Novos dados para o Paleolítico Superior final da Estremadura Portuguesa: resultados preliminares dos trabalhos arqueológicos de 1997-2003 na Lapa dos Coelhos (Casais Martanes, Torres Novas). Promontoria 2 (2): 157-192.

Aubry, Thierry, Francisco Imeida, Ana Cristina Arújo, and Marc Tiffagom 2008 L'Exploita des Matieres Premieres Lithiques au Magdalenien Final en Estremadure Portugaise: Donnees Sur Les Sites de Lapa do Coelhos et de L'abri 1 de Vale dos Covões. Proceedings of the XV World Cngress of 
the International Union for Prehistoric and Protohistorical Sciences: 5767. Lisbon.

Aubry, Thierry and Marina de Araújo Igreja

2009 Economy of lithic raw material during the Upper Paleolithic of the Côa Valley and the Sicó Massif (Portugal): technological and functional perspectives. Proceedings of the Workshop Functional Studies of Non Flint Stone Tools: Methodological Improvements and Archaeological Inferences: 1-25. Lisbon.

Bicho, Nuno Ferreira 2000 Technological Change in the Final Upper Paleolithic of Rio Maior. CEIPHAR, Tomar, Portugal.

2002 Lithic Raw Material Economy and Hunter-Gatherer Mobility in the Late Glacial and Early Postglacial in Portuguese Prehistory. Lithic Raw Material Economies in Late Glacial and Early Postglacial Europe. L. E. Fisher and B. V. Eriksen, Archaeopres: 161-179.

Bicho, Nuno and Jonathan Haws 2012 The Magdalenian in central and southern Portugal: Human ecology at the end of the Pleistocene. Quaternary International 272-273: 6-16.

Bicho, Nuno, Jonathan Haws, and Bryan Hockett 2006 Two Sides of the same coin- rocks, bones, and site function of Picareiro Cave, Central Portugal. Journal of Anthropological Archaeology 25(4): 485-499. 
Bicho, Nuno, Bryan Hockett, Jonathan Haws, and William Belcher 2000 Hunter-Gatherer subsistence at the end of the Pleistocene: Preliminary results from Picareiro Cave, Central Portugal. Antiquity 74(285): 500-506.

Binford, Lewis Roberts

1979 Organization and formation processes: looking at curated technologies. Journal of Anthropological Research 35:255-273.

Bleed, Peter

1986 The optimal design of hunting weapons: maintainability or reliability. American Antiquity 51(4): 737-747.

Bousman, C. Britt

1993 Hunter-gatherer adaptations, economic risk and tool design. Lithic Technology 18:59-86.

Combourieu Nebout, Nathalie, O. Peyron, I. Dormoy, Stéphanie Desprat, Celia Beaudouin, U. Kotthoff, and Fabienne Marret

2009 Rapid climatic variability in the west Mediterranean during the last 25,000 years from high resolution pollen data. Climate of the Past 5: 503-521.

De Sonneville-Bordes, Denise

1963 Upper Paleolithic Cultures in Western Europe. Science 142(3590): 347-355.

De Sonneville-Bordes, Denise and Jean Perrot 1954 Lexique typologique du Paléolithique supérieur. Bulletin de la Société Préhistorique Française 51: 327-335. 
1955 Lexique typologique du Paléolithique supérieur. Bulletin de la Société Préhistorique Française 52: 76-79.

1956 Lexique typologique du Paléolithique supérieur. Bulletin de la Société Préhistorique Française 53: 408-412,547-559.

Fletcher, William and Maria Fernanda Sánchez Goñi

2008 Orbital- and sub-orbital-scale climate impacts on vegetation of the western Mediterranean basin over the last 48,000yr. Quaternary Research 70: 451-464.

Gamiero, Cristina

2007 Bladelet debitage microliths and production during the Portuguese tardiglacial. Presentation of the program for the revision of available data. Proceedings of the Congress of Archaeology Peninsular 4: 173184. Faro.

2012 La variabilité régionale des industries lithiques de la fin du Paléolithique supérieur au Portugal. Unpublished Ph.D. dissertation, Department of History, Art, and Archaeology, Univeristy of Paris I- PanthéonSorbonne, Paris.

Gameiro, Cristina and Francisco Almeida

2004 A ocupação da camada 3 da Lapa dos Coelhos (Casais Martanes, Torres Novas). Novos elementos sobre a produção de suportes lamelares durante o Magdalenense Final da Estremadura Portuguesa. Promontoria 2(2): 193-238. 
Haws, Jonathan

2003 An Investigation of Late Upper Paleolithic and Epipaleolithic HunterGatherer Subsistence and Settlement Patterns in Central Portugal. Unpublished Ph.D. dissertation, Department of Anthropology, University of Wisconsin. Madison.

Inizan, Marie-Louise, Michéle Reduron-Ballinger, Hélène Roche, and Jacques Tixier 1999 Technology and Termonology of Knapped Stone. Translated by J. Féblot-Augustins. Cercle de Recherches et d'Etudes Préhistoriques, Nanterre.

Manso, Cláudia Maria Ferreirinha de Sousa 2015 Indústrias Líticas do Plistocénico Superior no Vale do Rôto (Bombarral): Lapa do Suão. Unpublished Master's thesis, Department of Arts and Humanities, University of Algarve. Faro.

Marks, Anthony, Nuno Bicho, João Zilhão, and C. Reid Ferring 1994 Upper Pleistocene Prehistory in Portuguese Estremadura. Journal of Field Archaeology 21(1): 53-68.

Matias, Henrique Afonso Manuel 2012 O Aprovisionamento de Matérias-primas Líticas na Gruta da Oliveira (Torres Noves). Unpublished Master's thesis. Department of Geology, University of Lisbon. Lisbon. 
Moreno, Eva, Nicolas Thouveny, Doriane Delanghe, I. Nick McCave, and Nick J. Shackleton

2002 Climate and oceanographic changes in the Northeast Atlantic reflected by magnetic properties of sediments deposited on the Portuguese Margin during the last 340 ka. Earth and Planetary Science Letters 2002: 465480.

National Oceanic and Atmospheric Administration

2008 Heinrich and Dansgaard-Oeschger events. Electronic document, https://www.ncdc.noaa.gov/paleo/abrupt/data3.html, accessed January 23, 2017.

Naughton, Filipa, Maria Fernanda Sanchez Goñi, T. Rodrigues, Emília Salgueiro, Susana Costas, Stéphanie Desprat, Ellinor Michel, L. Rossignol, Sébastien Zaragosi, and Antje Helga Luise Voelker

2015 Climate variability across the last deglaciation in NW Iberia and its margin. Quaternary International, in press.

Pereira, Telmo Jorge Ramos

2010 A Exploração do Quartzito na Faixa Atlântica Peninsular no Final do Plistocénico. Unpublished Ph.D. dissertation, Department of Human and Social Sciences, University of Algarve, Faro.

Pereira, Telmo and Michael M. Benedetti

2013 A model for raw material management as a response to local and global environmental constraints. Quaternary International 318: 19-32. 
Pereira, Telmo, João Cascalheira, João Marreiros, Francisco Almeida, Nuno Bicho

2012a Variations in quartzite exploitation during the Upper Paleolithic of

Southwest Iberian Peninsula. Trabajos de Prehistoria 69(2): 232-256

Pereira, Telmo, Francisco Almeida, Juan Gibaja, Trenton Holliday, and Nuno Bicho

2012b Hot They Did It: Gravettian Quartzite Flakes From Western Iberia. In Flakes Not Blades: The Role of Flake Production at the Onset of the Upper Paleolithic in Europe, edited by Andreas Pastoors and Marco Persani, pp. 25-50. Mettmann, Germany.

Pereira, Telmo, Caterina Andrade, Mafalda Costa, Anne Farias, José Mirão, and António Faustino Carvalho

2015 Lithic economy and territory of Epipaleolithic hunter-gatherers in the Middle Tagus: The case of Pena d'Agua (Portugal). Quaternary International, in press.

Salgueiro, Emília, Filipa Naughton, Antje Helga Luise Voelker, Lucia de Abreu, Ana Alberto, Linda Rossignol, Josette Duprat, Vitor H. Magalhães, Sandra Vaqueiro. Jean-Louis Turon, and Fatima Abrantes

2014 Past circulation along the western Iberian margin: a time slice vision from the Last Glacial to the Holocene. Quaternary Science Reviews 106: 316-329. 
Sánchez Goñi, Maria Fernanda, Frédérique Eynaud, Jean-Louis Turon, and Nicholas Shackleton

1999 High Resolution palynological record off the lberian margin: direct landsea correlation for the Last Interglacial complex. Earth and Planetary Science Letters 171: 123-137.

Sánchez Goñi, Maria Fernanda, Jean-Louis Turon, Frédérique Eynaud, and Sandra Gendreau

2000 European Climatic Response to Millennial-Scale Changes in the Atmosphere-Ocean System during the Last Glacial Period. Quaternary Research 54: 394-403.

Sánchez Goñi, Maria Fernanda and Francesco d'Errico

2005 La Historia de la vegetación y el clima del ultimo ciclo climático (OIS5OIS1, 140.000-10.000 años BP) en la Península lbérica y su possible impacto sobre los grupos paleolíticos. Museo de Altamira Monografías 20: $115-129$.

Sánchez Goñi, Maria Fernanda, Amaelle Landais, William J. Fletcher, Filipa Naughton, Stéphanie Desprat, and Josette Duprat 2008 Contrasting impacts of Dansgaard-Oeschger events over a western European latitudinal transect modulated by orbital parameters. Quaternary Science Reviews 27: 1136-1151.

Straus, Lawrence Guy

1996 The Archaeology of the Pleistocene-Holocene Transition in Southwest Europe. In Humans at the End of the Ice Age: The Archaeology of the 
Pleistocene-Holocene Transition, edited by Lawrence Guy Straus, Berit Valentin Eriksen Jon M. Erlandson, and David R. Yesner, pp.83-99.

Plenum Press, New York.

Thacker, Paul

1996 Hunter Gatherer Lithic Economy and Settlement Systems:

Understanding Regional Assemblage Variability in the Upper

Paleolithic of Portuguese Estremadura. In Stone Tools: Theoretical

Insights into Human Prehistory, edited by George H. Odell, pp. 101-124.

Plenum Press, New York.

Zilhão, João

1997a O Paleolítico Superior da Estremadura portuguesa Volume I. Colibri. Lisboa.

1997b O Paleolítico Superior da Estremadura portuguesa Volume II. Colibri. Lisboa 


\section{APPENDIX I: SITE CHRONOLOGY}

\section{This table presents the current absolute dates for Lapa do Picareiro}

\section{(provided by Haws 2017). Layer F/G is highlighted.}

\begin{tabular}{|c|c|c|c|c|c|c|c|c|c|c|}
\hline Level & Sample ID & $\begin{array}{l}\text { Depth } \\
\text { (cm) }\end{array}$ & $\begin{array}{l}\text { Cultural } \\
\text { affiliation }\end{array}$ & $\begin{array}{l}\text { Lab } \\
\text { number }\end{array}$ & $\begin{array}{l}\text { Sample } \\
\text { material }\end{array}$ & ${ }^{14} \mathrm{C}$ age & $\begin{array}{c}\text { cal BP } \\
\text { range }^{a} \\
(2- \\
\text { sigma })\end{array}$ & $\begin{array}{l}\delta^{13} \mathrm{C} \\
(\% \circ)\end{array}$ & $\% \mathrm{C}$ & $\mathrm{C}: \mathrm{N}$ \\
\hline \multicolumn{11}{|l|}{$\mathrm{A}$} \\
\hline \multirow[t]{2}{*}{ B } & LP.C5.B & -85 & Epipaleolithic & $\begin{array}{l}\text { UGAMS- } \\
9098\end{array}$ & charcoal & $8,500 \pm 30$ & $\begin{array}{l}9,535- \\
9,475\end{array}$ & -25.0 & & \\
\hline & LP.I5.top & -75 & Epipaleolithic & $\begin{array}{l}\text { UGAMS- } \\
9099\end{array}$ & charcoal & $8,700 \pm 30$ & $\begin{array}{c}9,735- \\
9,550\end{array}$ & -24.5 & & \\
\hline $\begin{array}{c}\mathrm{C} \\
\text { (outside) }\end{array}$ & LP.K13.2B & & Neolithic & Wk-7439 & charcoal & $6,580 \pm 90$ & & -25.9 & & \\
\hline $\begin{array}{c}\mathrm{Ca} \\
\text { (outside) }\end{array}$ & LP.K13.3 & & Neolithic & Wk-7440 & charcoal & $6,970 \pm 80$ & & -27.7 & & \\
\hline $\begin{array}{c}\mathrm{C} \\
\text { (inside) }\end{array}$ & LP.E12.C1 & $\begin{array}{c}-110- \\
115\end{array}$ & & Wk-41388 & bone & $10,716 \pm 42$ & $\begin{array}{c}12,727- \\
12,589\end{array}$ & $\mathrm{n} / \mathrm{a}$ & & $\mathrm{n} / \mathrm{a}$ \\
\hline $\mathrm{D}$ & LP.G4.D1 & $\begin{array}{c}-115- \\
125\end{array}$ & Epipaleolithic & Wk-6676 & charcoal & $8,310 \pm 130$ & $\begin{array}{l}9,528- \\
9,014\end{array}$ & -25.2 & & \\
\hline E upper & LP.D6.E5 & $\begin{array}{c}-145- \\
150\end{array}$ & Magdalenian & Wk-4217 & charcoal & $10,070 \pm 80$ & $\begin{array}{c}11,980- \\
11,307\end{array}$ & -24.2 & & \\
\hline E middle & LP.D6.E8 & $\begin{array}{c}-160- \\
165\end{array}$ & Magdalenian & Wk-5431 & charcoal & $11,700 \pm 120$ & $\begin{array}{c}13,764- \\
13,296\end{array}$ & -24.7 & & \\
\hline \multirow[t]{2}{*}{ E lower } & LP.D6.E10 & $\begin{array}{c}-170- \\
175\end{array}$ & Magdalenian & Wk-4218 & charcoal & $11,550 \pm 120$ & $\begin{array}{c}13,605- \\
13,119\end{array}$ & -24.3 & & \\
\hline & LP.D8.E14 & $\begin{array}{c}-185- \\
190\end{array}$ & & Wk-10434 & charcoal & $12,498 \pm 159$ & $\begin{array}{c}15,228- \\
14110\end{array}$ & -23.1 & & \\
\hline \multirow[t]{2}{*}{$\mathrm{F}$} & LP.D6.F3 & $\begin{array}{c}-190- \\
195\end{array}$ & Magdalenian & Wk-4219 & charcoal & $11,780 \pm 90$ & $\begin{array}{r}13,772- \\
13,442\end{array}$ & -24.7 & & \\
\hline & LP.F5.F10 & $\begin{array}{c}-215- \\
220\end{array}$ & & Wk-6677 & charcoal & $12,210 \pm 100$ & $\begin{array}{c}14,607- \\
13,778\end{array}$ & -24.3 & & \\
\hline G & LP.D5 & & Magdalenian & OxA-5527 & charcoal & $12,320 \pm 90$ & $\begin{array}{c}14,824- \\
14,011\end{array}$ & -23.7 & & \\
\hline $\mathrm{H}$ & & & $\mathrm{n} / \mathrm{a}$ & & & & & & & \\
\hline $\begin{array}{c}\mathrm{I}(\mathrm{SB} \\
\text { surface) }\end{array}$ & LP.ZZ9.1271 & -240 & Magdalenian & Wk-41257 & bone & $12,260 \pm 33$ & $\begin{array}{c}14,323- \\
14,028\end{array}$ & -20.8 & 37.67 & 3.47 \\
\hline $\begin{array}{c}\mathrm{I}(\mathrm{SB} \\
\text { surface })\end{array}$ & LP.ZZ10.1279 & -229 & Magdalenian & $\begin{array}{l}\text { UGAMS- } \\
20480\end{array}$ & charcoal & $11,760 \pm 30$ & $\begin{array}{c}13,719- \\
13,467\end{array}$ & -25.2 & & \\
\hline \multirow[t]{3}{*}{$\mathrm{J}$} & LP.D5.J6 & $\begin{array}{c}-290- \\
295\end{array}$ & Magdalenian & Wk-10433 & charcoal & $10,486 \pm 110$ & $\begin{array}{c}12,678- \\
12,052\end{array}$ & -24.3 & & \\
\hline & LP.D5.J10.49 & -310 & & Wk-12129 & bone & $12,121 \pm 65$ & $\begin{array}{c}14,150- \\
13,777\end{array}$ & -20.8 & & 2.97 \\
\hline & LP.D7.J2 & $\begin{array}{c}-240- \\
245\end{array}$ & & Wk-6678 & charcoal & $11,877 \pm 81$ & $\begin{array}{c}13,950- \\
13,485\end{array}$ & -24.1 & & \\
\hline $\mathrm{K}$ & LP.F6.K5.5 & $\begin{array}{l}-271 \\
\mathrm{~cm}\end{array}$ & Magdalenian & Wk-31354 & bone & $15,035 \pm 87$ & $\begin{array}{c}18,512- \\
18,006\end{array}$ & -20.7 & 41.99 & 3.38 \\
\hline L & LP.E9.L & $\begin{array}{l}-282 \\
\mathrm{~cm}\end{array}$ & Magdalenian & $\begin{array}{c}\text { UGAMS- } \\
17664\end{array}$ & charcoal & $15,680 \pm 40$ & $\begin{array}{c}19,035- \\
18,800\end{array}$ & -23.7 & & \\
\hline \multicolumn{11}{|l|}{$\mathrm{M}$} \\
\hline $\mathrm{N}$ & LP.D5.N1.9 & $\begin{array}{l}-332 \\
\mathrm{~cm}\end{array}$ & & Wk-16417 & bone & $16,389 \pm 111$ & $\begin{array}{c}20,070- \\
19,511\end{array}$ & -19.5 & 13.7 & 3.52 \\
\hline \multirow[t]{3}{*}{$\mathrm{O}$} & LP.G9.O & $\begin{array}{l}-300 \\
\mathrm{~cm}\end{array}$ & Solutrean? & $\begin{array}{c}\text { Beta- } \\
247965\end{array}$ & charcoal & $17,480 \pm 100$ & $\begin{array}{l}21,450- \\
20,805\end{array}$ & -24.4 & & \\
\hline & LP.YY11.115 & $\begin{array}{l}-340 \\
\mathrm{~cm}\end{array}$ & & $\begin{array}{c}\text { UGAMS- } \\
23724\end{array}$ & charcoal & $16,280 \pm 40$ & $\begin{array}{c}19,854- \\
19,497\end{array}$ & -24.3 & & \\
\hline & LP.YY10.327 & $\begin{array}{l}-368 \\
\mathrm{~cm}\end{array}$ & & $\begin{array}{l}\text { UGAMS- } \\
24606\end{array}$ & charcoal & $17,570 \pm 45$ & $\begin{array}{l}21,451- \\
21,002\end{array}$ & -22.8 & & \\
\hline \multicolumn{11}{|l|}{$\mathrm{P}$} \\
\hline$Q$ & & & Solutrean & & & & & & & \\
\hline \multirow[t]{3}{*}{$\mathrm{R}$} & LP.E6.R1.5 & $\begin{array}{l}-383 \\
\mathrm{~cm}\end{array}$ & Solutrean & $\begin{array}{l}\text { Beta- } \\
234370\end{array}$ & charcoal & $8,670 \pm 40$ & & -25.0 & & \\
\hline & LP.E7.R & $\begin{array}{l}-385 \\
\mathrm{~cm}\end{array}$ & & $\begin{array}{l}\text { UGAMS- } \\
03415\end{array}$ & charcoal & $19,100 \pm 70$ & $\begin{array}{c}23,335- \\
22,758\end{array}$ & -24.3 & & \\
\hline & LP.B7.337 & $\begin{array}{l}-412 \\
\mathrm{~cm}\end{array}$ & & $\begin{array}{c}\text { UGAMS- } \\
23719\end{array}$ & charcoal & $19,090 \pm 50$ & $\begin{array}{l}23,272- \\
22,772\end{array}$ & -25.1 & & \\
\hline \multirow[t]{2}{*}{ S } & LP.E6.S1.31 & $\begin{array}{l}-406 \\
\mathrm{~cm}\end{array}$ & Solutrean & $\begin{array}{c}\text { Beta- } \\
234371\end{array}$ & charcoal & $19,290 \pm 80$ & $\begin{array}{l}23,510- \\
22,965\end{array}$ & -24.4 & & \\
\hline & LP.B7.344 & $\begin{array}{l}-420 \\
\mathrm{~cm}\end{array}$ & & $\begin{array}{c}\text { UGAMS- } \\
23720\end{array}$ & charcoal & $18,930 \pm 50$ & $\begin{array}{l}23,001- \\
22,569\end{array}$ & -24.4 & & \\
\hline
\end{tabular}




\begin{tabular}{|c|c|c|c|c|c|c|c|c|c|c|}
\hline $\mathrm{T}$ & LP.F8.T5.1032 & $\begin{array}{l}-421 \\
\mathrm{~cm}\end{array}$ & & Wk-37655 & bone & $18,957 \pm 79$ & $\begin{array}{l}23,069- \\
22,551\end{array}$ & -20.3 & 43.67 & 3.22 \\
\hline & LP.B7.505 & $\begin{array}{l}-466 \\
\mathrm{~cm}\end{array}$ & & $\begin{array}{l}\text { UGAMS- } \\
23721\end{array}$ & charcoal & $20,710 \pm 55$ & $\begin{array}{l}25,248- \\
24,615\end{array}$ & -22.6 & & \\
\hline & LP.B7.788 & $\begin{array}{c}-488 \\
\mathrm{~cm}\end{array}$ & & $\begin{array}{l}\text { UGAMS- } \\
23722\end{array}$ & charcoal & $20,630 \pm 55$ & $\begin{array}{l}25,146- \\
24,530 \\
\end{array}$ & -23.3 & & \\
\hline & LP.B9.92 & $\begin{array}{l}-449 \\
\mathrm{~cm}\end{array}$ & & $\begin{array}{l}\text { UGAMS- } \\
23718\end{array}$ & charcoal & $20,240 \pm 50$ & $\begin{array}{l}24,508- \\
24,104\end{array}$ & -23.7 & & \\
\hline & LP.YY11.436 & $\begin{array}{l}-446 \\
\mathrm{~cm}\end{array}$ & & $\begin{array}{l}\text { UGAMS- } \\
23725 \\
\end{array}$ & charcoal & $20,320 \pm 50$ & $\begin{array}{l}24,586- \\
24,177 \\
\end{array}$ & -25.0 & & \\
\hline & LP.YY11.666 & $\begin{array}{l}-451 \\
\mathrm{~cm}\end{array}$ & & $\begin{array}{l}\text { UGAMS- } \\
23726\end{array}$ & charcoal & $20,530 \pm 50$ & $\begin{array}{l}24,999- \\
24,437\end{array}$ & -22.9 & & \\
\hline & LP.XX12.21 & $\begin{array}{l}-456 \\
\mathrm{~cm}\end{array}$ & & $\begin{array}{l}\text { UGAMS- } \\
23727\end{array}$ & charcoal & $19,530 \pm 50$ & $\begin{array}{l}23,761- \\
23,276\end{array}$ & -26.0 & & \\
\hline \multirow[t]{2}{*}{ (T4) } & E5.T4 & $\begin{array}{l}-455- \\
460\end{array}$ & Solutrean? & $\begin{array}{c}\text { Beta- } \\
208221\end{array}$ & charcoal & $20,240 \pm 110$ & $\begin{array}{l}24,615- \\
23,984\end{array}$ & -23.6 & & \\
\hline & E5.T4 & $\begin{array}{c}-455- \\
460 \\
\end{array}$ & & $\begin{array}{c}\text { Beta- } \\
229781\end{array}$ & bone & $20,700 \pm 100$ & $\begin{array}{l}25,276- \\
24,545\end{array}$ & -21.0 & & \\
\hline (T8) & LP.E7.T8.46 & $\begin{array}{l}-486 \\
\mathrm{~cm}\end{array}$ & Gravettian? & Wk- 37656 & charcoal & $23,097 \pm 131$ & $\begin{array}{l}27,641- \\
27,146\end{array}$ & -23.8 & & \\
\hline \multirow[t]{3}{*}{ U } & LP.E6.U & $\begin{array}{c}-490- \\
495 \\
\end{array}$ & Gravettian? & $\begin{array}{c}\text { Beta- } \\
208222\end{array}$ & charcoal & $22,660 \pm 240$ & $\begin{array}{l}27,461- \\
26,395 \\
\end{array}$ & -26.1 & & \\
\hline & LP.F6.U1 & $\begin{array}{l}-488 \\
\mathrm{~cm}\end{array}$ & & $\begin{array}{c}\text { Beta- } \\
234373\end{array}$ & charcoal & $22,560 \pm 110$ & $\begin{array}{l}27,220- \\
26,525\end{array}$ & -23.1 & & \\
\hline & LP.F6.U3 & $\begin{array}{l}-505 \\
\mathrm{~cm}\end{array}$ & & $\begin{array}{c}\text { Beta- } \\
234374\end{array}$ & charcoal & $22,590 \pm 110$ & $\begin{array}{l}27,246- \\
26,550 \\
\end{array}$ & -23.8 & & \\
\hline V & LP.F6.V1.2071 & $\begin{array}{l}-525 \\
\mathrm{~cm}\end{array}$ & & Wk-31353 & bone & $25,579 \pm 173$ & $\begin{array}{l}30,320- \\
29,254 \\
\end{array}$ & -20.2 & 44.27 & 3.31 \\
\hline W & LP.F8.W1.1105 & $\begin{array}{l}-516 \\
\mathrm{~cm}\end{array}$ & Gravettian & Wk-30539 & bone & $26,505 \pm 270$ & $\begin{array}{l}31,164- \\
30,184\end{array}$ & -19.4 & 42.3 & 3.2 \\
\hline $\mathrm{x}$ & LP.D10.27 & $\begin{array}{l}-516 \\
\mathrm{~cm}\end{array}$ & & $\begin{array}{l}\text { UGAMS- } \\
23723\end{array}$ & charcoal & $27,230 \pm 80$ & $\begin{array}{l}31,331- \\
30,996\end{array}$ & -24.2 & & \\
\hline Y & LP.E9.Y.89 & $\begin{array}{l}-563 \\
\mathrm{~cm}\end{array}$ & & Wk-41389 & bone & $28,430 \pm 210$ & $\begin{array}{l}33,041- \\
31,633 \\
\end{array}$ & -19.0 & 41.04 & 3.29 \\
\hline \multirow[t]{3}{*}{ Z } & LP.F7.Z1 & $\begin{array}{c}-560- \\
565 \\
\end{array}$ & Gravettian? & $\begin{array}{l}\text { UGAMS- } \\
03417\end{array}$ & bone & $22,190 \pm 80$ & & -20.3 & & \\
\hline & $\begin{array}{l}\text { LP.F7.Z2.1117 + } \\
\text { F6.Z1.2081 }\end{array}$ & $\begin{array}{c}-572 \\
\mathrm{~cm} \\
-573 \\
\mathrm{~cm}\end{array}$ & & Wk-30538 & bone & $28,161 \pm 329$ & $\begin{array}{l}32,984- \\
31,307\end{array}$ & -19.6 & 43.5 & 3.3 \\
\hline & LP.G6.Z1.10 & $\begin{array}{l}-564 \\
\mathrm{~cm}\end{array}$ & & Wk-32280 & bone & $29,054 \pm 224$ & $\begin{array}{l}33,769- \\
32,690 \\
\end{array}$ & -19.4 & 43.48 & 3.24 \\
\hline \multicolumn{11}{|l|}{ AA } \\
\hline BB & LP.E7.BB.2000 & $\begin{array}{l}-592 \\
\mathrm{~cm}\end{array}$ & & Wk-32281 & bone & $30,027 \pm 207$ & $\begin{array}{l}34,512- \\
33,745\end{array}$ & -19.4 & 42.93 & 3.24 \\
\hline \multicolumn{11}{|l|}{$\mathrm{CC}$} \\
\hline \multicolumn{11}{|l|}{ DD } \\
\hline EE & & & & & & & & & & \\
\hline \multirow[t]{5}{*}{$\mathrm{FF}$} & LP.F7.FF & $\begin{array}{l}-625- \\
635 \\
\end{array}$ & Middle P & $\begin{array}{c}\text { Beta- } \\
247964 \\
\end{array}$ & charcoal & $28,610 \pm 300$ & $\begin{array}{l}3,485- \\
31,705 \\
\end{array}$ & -22.3 & & \\
\hline & LP.F7.FF.1140 & $\begin{array}{l}-644 \\
\mathrm{~cm}\end{array}$ & & Wk-28843 & bone & $27,721 \pm 260$ & $\begin{array}{l}32,291- \\
31,087\end{array}$ & $\mathrm{n} / \mathrm{a}$ & & $n / a$ \\
\hline & LP.F7.FF.1132 & $\begin{array}{l}-640 \\
\mathrm{~cm}\end{array}$ & & Wk-32219 & bone & $32,997 \pm 263$ & $\begin{array}{l}38,086- \\
36,355\end{array}$ & -19.3 & 43.02 & 3.25 \\
\hline & LP.E9.FF & $\begin{array}{c}\sim-625 \\
\mathrm{~cm}\end{array}$ & & Wk-41259 & charcoal & $33,238 \pm 419$ & $\begin{array}{c}38,524- \\
36,381 \\
\end{array}$ & $\mathrm{n} / \mathrm{a}$ & & \\
\hline & LP.F9.FF & $\begin{array}{c}\sim-610 \\
\mathrm{~cm}\end{array}$ & & $\begin{array}{l}\text { UGAMS- } \\
20479 \\
\end{array}$ & charcoal & $32,200 \pm 90$ & $\begin{array}{l}36,355- \\
35,800\end{array}$ & -24.0 & 57.04 & \\
\hline GG & LP.G6.GG.1090 & $\begin{array}{c}-633 \\
\mathrm{~cm}\end{array}$ & & Wk-41258 & bone & $32,063 \pm 336$ & $\begin{array}{l}36,726- \\
35,173 \\
\end{array}$ & -19.0 & 38.74 & 3.44 \\
\hline \multicolumn{11}{|l|}{$\mathrm{HH}$} \\
\hline \multicolumn{11}{|l|}{ II } \\
\hline JJ & LP.F7.JJ1 & $\begin{array}{l}-690- \\
700 \\
\end{array}$ & Middle P & $\begin{array}{l}\text { UGAMS- } \\
03416 \\
\end{array}$ & bone & $24,160 \pm 100$ & & -19.6 & & \\
\hline (JJ4) & LP.F7.JJ4.3003 & $\begin{array}{l}-744 \\
\mathrm{~cm}\end{array}$ & & Wk-28844 & bone & $40,078 \pm 1239$ & $\begin{array}{c}46,381- \\
42,094 \\
\end{array}$ & -19.9 & 39.53 & 3.4 \\
\hline (JJ4) & LP.F7.JJ4 & $\begin{array}{l}-750 \\
\mathrm{~cm}\end{array}$ & & $\begin{array}{c}\text { UGAMS- } \\
07769\end{array}$ & charcoal & $41,480 \pm 220$ & $\begin{array}{c}45,420- \\
44,451 \\
\end{array}$ & -25.1 & 55.54 & \\
\hline \multicolumn{11}{|l|}{ KK } \\
\hline \multicolumn{11}{|l|}{$\mathrm{LL}$} \\
\hline \multicolumn{11}{|l|}{$\mathrm{MM}$} \\
\hline $\mathrm{NN}$ & & & & & & & & & & \\
\hline
\end{tabular}

${ }^{a}$ Paula J Reimer, Edouard Bard, Alex Bayliss, J Warren Beck, Paul G Blackwell, Christopher Bronk Ramsey, Pieter M Grootes, Thomas P Guilderson, Haflidi Haflidason, Irka Hajdas, Christine Hatté, Timothy J Heaton, Dirk L Hoffmann, Alan G Hogg, Konrad A Hughen, K Felix Kaiser, Bernd Kromer, Sturt W Manning, Mu Niu, Ron W Reimer, David A Richards, E Marian Scott, John R Southon, Richard A Staff, Christian S M Turney, Johannes van der Plicht. 2013. IntCal13 and Marine13 Radiocarbon Age Calibration Curves 0-50,000 Years cal BP. Radiocarbon 55(4): 1869-1887. 
APPENDIX II: ANALYTIC INDEXES

- Assemblage Integrity:

○ (Chips/All assemblage ${ }^{*} 100$

○ $(2,023 / 3,207)^{*} 100=63.08 \%$

\subsection{QUANTITATIVE ANALYSIS}

- Raw Material Use:

- Acquisition: Nodules/Pebbles/Cobbles + Tested nodules + Blanks (complete and proximal) with more than $50 \%$ of cortex.

- Acquisition for all material types:

- $5+(47+1)=53$

- $(53 / 3,207)^{\star} 100=1.65 \%$

- Less Chips: $(53 / 1,184)^{*} 100=4.48 \%$

- Acquisition for Chert:

- $0+(20+1)=20$

- $(20 / 3,207)^{\star} 100=0.62 \%$

- Less Chips: $(20 / 1,184)^{\star} 100=1.70 \%$

- Acquisition for Quartzite:

- $5+(21+0)=26$

- $(26 / 3,207)^{\star} 100=0.81 \%$

- Less Chips: $(26 / 1,184)^{*} 100=2.20 \%$ 
- Acquisition for Quartz:

- $0+(4+0)=4$

- $(4 / 3,207)^{*} 100=0.12 \%$

- Less Chips: $(4 / 1,184)^{*} 100=0.34 \%$

- Production: Blanks (complete and proximal) + Cores

- Production for Complete Assemblage:

- $(300+62)+69=431$

- $(431 / 3,207)^{\star} 100=13.44 \%$

- Less Chips: $(431 / 1,184)^{*} 100=36.40 \%$

○ Production for Chert:

- $(193+40)+27=260$

- $(260 / 3,207)^{*} 100=8.11 \%$

- Less Chips: $(260 / 1,184)^{*} 100=21.94 \%$

- Production for Quartzite:

- $(81+12)+23=116$

- $(116 / 3,207)^{\star} 100=3.62 \%$

- Less Chips: $(116 / 1,184)^{*} 100=9.80 \%$

- Production for Quartz:

- $(24+10)+18=52$

- $(52 / 3,207) * 100=1.62 \%$

- Less Chips: $(52 / 1,184)^{\star} 100=4.39 \%$ 
○ Retouch: Retouched tools

- Retouch for Complete Assemblage:

- 211

- $(211 / 3,207)^{*} 100=6.60 \%$

- Less Chips: $(211 / 1,184)^{\star} 100=17.82 \%$

○ Retouch for Chert:

- 189

- $(189 / 3,207)^{*} 100=5.89 \%$

- Less Chips: $(189 / 1,184)^{*} 100=15.96 \%$

○ Retouch for Quartzite:

- 3

- $(3 / 3,207)^{\star} 100=0.09 \%$

- Less Chips: $(3 / 1,184)^{*} 100=0.25 \%$

○ Retouch for Quartz:

- 19

- $(19 / 3,207)^{*} 100=0.59 \%$

- Less Chips: $(19 / 1,184)^{*} 100=1.60 \%$ 
- Representation of the Phases of Reduction Sequence:

- Acquisition/Production and Retouch/Production

- All Material Types:

- Acquisition/Production:

- $[(53 / 3,207) /(431 / 3,207)]^{*} 100=12.29 \%$

- Less Chips: $[(53 / 1,184) /(431 / 1,184)]^{*} 100=12.29 \%$

- Retouch/Production:

- $[(211 / 3,207) /(431 / 3,207)]^{*} 100=48.96 \%$

- Less Chips: $[(211 / 1,184) /(431 / 1,184)]^{*} 100=48.96 \%$

○ Chert:

- Acquisition/Production:

- $[(20 / 3,207) /(431 / 3,207)]^{\star} 100=4.64 \%$

- Less Chips: $[(20 / 1,184) /(431 / 1,184)]^{\star} 100=4.64 \%$

- Retouch/Production:

- $[(189 / 3,207) /(431 / 3,207)]^{*} 100=43.85 \%$

- Less Chips: $[(189 / 1,184) /(431 / 1,184)]^{\star} 100=43.85 \%$

○ Quartzite:

- Acquisition/Production:

- $[(26 / 3,207) /(431 / 3,207)]^{\star} 100=6.03 \%$

- Less Chips: $[(26 / 1,184) /(431 / 1,184)]^{*} 100=6.03 \%$

- Retouch/Production:

- $[(3 / 3,207) /(431 / 3,207)]^{*} 100=0.69 \%$

- Less Chips: $[(3 / 1,184) /(431 / 1,184)]^{\star} 100=0.69 \%$ 


\section{○ Quartz:}

- Acquisition/Production:

- $[(4 / 3,207) /(431 / 3,207)]^{\star} 100=0.93 \%$

- Less Chips: $[(4 / 1,184) /(431 / 1,184)]^{\star} 100=0.93 \%$

- Retouch/Production:

- $[(19 / 3,207) /(431 / 3,207)]^{\star} 100=4.41 \%$

- Less Chips: $[(19 / 1,184) /(431 / 1,184)]^{*} 100=4.41 \%$

\section{- Productivity by Raw Material}

- Blanks (Complete and Proximal) / Cores

- All Material Types:

- $(300+62) / 69=5.24$

- Chert:

- $(193+40) / 27=8.62$

○ Quartzite:

- $(81+12) / 23=4.04$

○ Quartz:

- $(24+10) / 18=1.89$ 


\section{- Debitage Preference}

○ Complete + Proximal (for each blank type by raw material); Percentage of assemblage with and without chips

○ Chert:

- Flake: $193+40=233$

- $(233 / 3,207)^{*} 100=7.26 \%$

- Less Chips : $(233 / 1,184)^{*} 100=19.67 \%$

- Blade: 8

- $(8 / 3,207)^{*} 100=0.24 \%$

- Less Chips: $(8 / 1,184)^{\star} 100=0.67 \%$

- Bladelet: $142+72=214$

- $(214 / 3,207)^{\star} 100=6.67 \%$

- Less Chips: $(214 / 1,184)^{*} 100=18.07 \%$

- Burin Spall: 53

- $(53 / 3,207)^{\star} 100=1.65 \%$

- Less Chips: $(53 / 1,184)^{\star} 100=4.48 \%$

\section{○ Quartzite:}

- Flake: $81+12=93$

- $(93 / 3,207)^{\star} 100=2.89 \%$

- Less Chips: $(93 / 1,184)^{\star} 100=7.85 \%$

- Blade: 2

- $(2 / 3,207)^{*} 100=0.06 \%$

- Less Chips: $(2 / 1,184)^{*} 100=0.17 \%$ 
- Bladelet: $3+2=5$

- $(5 / 3,207)^{*} 100=0.15 \%$

- Less Chips: $(5 / 1,184)^{*} 100=0.42 \%$

- Burin Spall: 9

- $(9 / 3,207)^{*} 100=0.28 \%$

- Less Chips: $(9 / 1,184)^{*} 100=0.76 \%$

\section{○ Quartz:}

- Flake: $24+10=34$

- $(34 / 3,207)^{\star} 100=1.06 \%$

- Less Chips: $(34 / 1,184)^{\star} 100=2.87 \%$

- Blade: 0

- $(0 / 3,207)^{\star} 100=0 \%$

- Less Chips: $(0 / 1,184)^{\star} 100=0 \%$

- Bladelet: $4+3=7$

- $(7 / 3,207)^{*} 100=0.22 \%$

- Less Chips: $(7 / 1,184)^{*} 100=0.59 \%$

- Burin Spall: 6

- $(6 / 3,207)^{*} 100=0.18 \%$

- Less Chips: $(6 / 1,184)^{*} 100=0.51 \%$ 


\section{- Debitage Technology}

- Frequency of core types by raw material; total cores in assemblage: 69

○ Chert:

- Bipolar: 1

- $(1 / 69)^{*} 100=1.45 \%$

- Chopper: 0

- $(0 / 69)^{*} 100=0 \%$

- Chipped Stone: 2

- $(2 / 69)^{*} 100=2.89 \%$

- Multidirectional: 8

- $(8 / 69)^{*} 100=11.59 \%$

- Prismatic: 14

- $(14 / 69)^{*} 100=20.29 \%$

- Pebble/Nodule: 0

- $(0 / 69)^{\star} 100=0 \%$

\section{- Quartzite:}

- Bipolar: 0

- $(0 / 69)^{*} 100=0 \%$

- Chopper: 13

- $(13 / 69)^{*} 100=18.84 \%$

- Chipped Stone: 0

- $(0 / 69)^{\star} 100=0 \%$ 
- Multidirectional: 1

- $(1 / 69)^{\star} 100=1.45 \%$

- Prismatic: 2

- $(2 / 69)^{\star} 100=2.89 \%$

- Pebble/Nodule: 0

- $(0 / 69)^{\star} 100=0 \%$

\section{○ Quartz:}

- Bipolar: 3

- $(3 / 69)^{\star} 100=4.34 \%$

- Chopper: 1

- $(1 / 69)^{*} 100=1.45 \%$

- Chipped Stone: 7

- $(7 / 69)^{*} 100=10.14 \%$

- Multidirectional: 2

- $(2 / 69)^{*} 100=2.89 \%$

- Prismatic: 2

- $(2 / 69)^{*} 100=2.89 \%$

- Pebble/Nodule: 1

- $(1 / 69)^{*} 100=1.45 \%$ 


\section{APPENDIX II: ASSEMBLAGE ANALYSIS}

\section{1:STATISTICAL BREAKDOWN}

\section{Layer F/G: Cores}

\begin{tabular}{|c|c|c|c|c|c|}
\hline \multicolumn{7}{|c|}{ Layer F/G Chert Cores } \\
\hline Length $(\mathrm{mm})$ & \multicolumn{2}{|c|}{ Width $(\mathrm{mm})$} & \multicolumn{2}{c|}{ Thickness $(\mathrm{mm})$} \\
\hline Mean & 28.34 & Mean & 23.81 & Mean & 16.77 \\
\hline Median & 24.76 & Median & 21.33 & Median & 15.49 \\
\hline Mode & \#N/A & Mode & \#N/A & Mode & 25.38 \\
\hline $\begin{array}{c}\text { Standard } \\
\text { Deviation }\end{array}$ & 11.02 & $\begin{array}{c}\text { Standard } \\
\text { Deviation }\end{array}$ & 8.42 & $\begin{array}{l}\text { Standard } \\
\text { Deviation }\end{array}$ & 6.87 \\
\hline
\end{tabular}

Table 6.1: Statistical breakdown of chert cores

\begin{tabular}{|c|c|c|c|c|c|}
\hline \multicolumn{7}{|c|}{ Layer F/G Quartz Cores } \\
\hline \multicolumn{2}{|c|}{ Length $(\mathrm{mm})$} & \multicolumn{2}{|c|}{ Width $(\mathrm{mm})$} & \multicolumn{2}{c|}{ Thickness $(\mathrm{mm})$} \\
\hline Mean & 30.70 & Mean & 27.16 & Mean & 14.67 \\
\hline Median & 25.63 & Median & 23.47 & Median & 12.35 \\
\hline Mode & \#N/A & Mode & \#N/A & Mode & \#N/A \\
\hline $\begin{array}{c}\text { Standard } \\
\text { Deviation }\end{array}$ & 16.44 & $\begin{array}{c}\text { Standard } \\
\text { Deviation }\end{array}$ & 11.20 & $\begin{array}{l}\text { Standard } \\
\text { Deviation }\end{array}$ & 8.19 \\
\hline
\end{tabular}

Table 6.2: Statistical breakdown of quartz cores

\begin{tabular}{|c|c|c|c|c|c|}
\hline \multicolumn{5}{|c|}{ Layer F/G Quartzite Cores } \\
\hline \multicolumn{2}{|c|}{ Length $(\mathrm{mm})$} & \multicolumn{2}{c|}{ Width $(\mathrm{mm})$} & \multicolumn{2}{c|}{ Thickness $(\mathrm{mm})$} \\
\hline Mean & 68.11 & Mean & 66.31 & Mean & 46.58 \\
\hline Median & 58.5 & Median & 66.02 & Median & 47.1 \\
\hline Mode & \#N/A & Mode & \#N/A & Mode & \#N/A \\
\hline $\begin{array}{l}\text { Standard } \\
\text { Deviation }\end{array}$ & 38.54 & $\begin{array}{l}\text { Standard } \\
\text { Deviation }\end{array}$ & 15.87 & $\begin{array}{c}\text { Standard } \\
\text { Deviation }\end{array}$ & 14.99 \\
\hline
\end{tabular}

Table 6.3: Statistical breakdown of quartzite cores 


\section{Layer F/G: Flakes}

\begin{tabular}{|c|c|c|c|c|c|}
\hline \multicolumn{5}{|c|}{ Layer F/G Chert Flakes } \\
\hline \multicolumn{2}{|c|}{ Length $(\mathrm{mm})$} & \multicolumn{2}{c|}{ Width $(\mathrm{mm})$} & \multicolumn{2}{c|}{ Thickness $(\mathrm{mm})$} \\
\hline Mean & 23.44 & Mean & 20.54 & Mean & 5.95 \\
\hline Median & 21.43 & Median & 18.96 & Median & 4.88 \\
\hline Mode & 36.83 & Mode & 26.43 & Mode & 2.78 \\
\hline $\begin{array}{c}\text { Standard } \\
\text { Deviation }\end{array}$ & 11.30 & $\begin{array}{c}\text { Standard } \\
\text { Deviation }\end{array}$ & 9.427 & $\begin{array}{c}\text { Standard } \\
\text { Deviation }\end{array}$ & 3.94 \\
\hline
\end{tabular}

Table 6.4: Statistical breakdown of chert flakes

\begin{tabular}{|c|c|c|c|c|c|}
\hline \multicolumn{7}{|c|}{ Layer F/G Quartz Flakes } \\
\hline Length $(\mathrm{mm})$ & \multicolumn{2}{|c|}{ Width $(\mathrm{mm})$} & \multicolumn{2}{c|}{ Thickness $(\mathrm{mm})$} \\
\hline Mean & 23.57 & Mean & 20.19 & Mean & 7.26 \\
\hline Median & 21.54 & Median & 16.77 & Median & 6.79 \\
\hline Mode & 14.69 & Mode & 21.01 & Mode & \#N/A \\
\hline $\begin{array}{l}\text { Standard } \\
\text { Deviation }\end{array}$ & 13.1 & $\begin{array}{l}\text { Standard } \\
\text { Deviation }\end{array}$ & 11.67 & $\begin{array}{l}\text { Standard } \\
\text { Deviation }\end{array}$ & 3.57 \\
\hline
\end{tabular}

Table 6.5: Statistical breakdown of quartz flakes

\begin{tabular}{|c|c|c|c|c|c|}
\hline \multicolumn{5}{|c|}{ Layer F/G Quartzite Flakes } \\
\hline \multicolumn{2}{|c|}{ Length $(\mathrm{mm})$} & \multicolumn{2}{c|}{ Width $(\mathrm{mm})$} & \multicolumn{2}{l|}{ Thickness $(\mathrm{mm})$} \\
\hline Mean & 35.96 & Mean & 31.62 & Mean & 9.88 \\
\hline Median & 32.55 & Median & 29.38 & Median & 8.44 \\
\hline Mode & \#N/A & Mode & \#N/A & Mode & 16.9 \\
\hline $\begin{array}{l}\text { Standard } \\
\text { Deviation }\end{array}$ & 16.91 & $\begin{array}{l}\text { Standard } \\
\text { Deviation }\end{array}$ & 14.46 & $\begin{array}{l}\text { Standard } \\
\text { Deviation }\end{array}$ & 5.32 \\
\hline
\end{tabular}

Table 6.6: Statistical breakdown of quartzite flakes

\section{Layer F/G: Blades}

\begin{tabular}{|c|c|c|c|c|c|}
\hline \multicolumn{5}{|c|}{ Layer F/G Chert Blades } \\
\hline \multicolumn{2}{|c|}{ Length $(\mathrm{mm})$} & \multicolumn{2}{c|}{ Width $(\mathrm{mm})$} & \multicolumn{2}{c|}{ Thickness $(\mathrm{mm})$} \\
\hline Mean & 39.16 & Mean & 16.09 & Mean & 5.48 \\
\hline Median & 40.19 & Median & 17.64 & Median & 5.24 \\
\hline Mode & \#N/A & Mode & \#N/A & Mode & \#N/A \\
\hline $\begin{array}{c}\text { Standard } \\
\text { Deviation }\end{array}$ & 16.61 & $\begin{array}{c}\text { Standard } \\
\text { Deviation }\end{array}$ & 5.64 & $\begin{array}{l}\text { Standard } \\
\text { Deviation }\end{array}$ & 2.64 \\
\hline
\end{tabular}

Table 6.7: Statistical breakdown of chert blades 


\begin{tabular}{|c|c|c|c|c|c|}
\hline \multicolumn{7}{|c|}{ Layer F/G: Quartzite Blades } \\
\hline Length $(\mathrm{mm})$ & \multicolumn{2}{|c|}{ Width $(\mathrm{mm})$} & \multicolumn{2}{c|}{ Thickness $(\mathrm{mm})$} \\
\hline Mean & 38.96 & Mean & 19.27 & Mean & 7.86 \\
\hline Median & 38.96 & Median & 19.27 & Median & 7.86 \\
\hline Mode & \#N/A & Mode & \#N/A & Mode & \#N/A \\
\hline $\begin{array}{c}\text { Standard } \\
\text { Deviation }\end{array}$ & 12.52 & $\begin{array}{c}\text { Standard } \\
\text { Deviation }\end{array}$ & 5.607 & $\begin{array}{c}\text { Standard } \\
\text { Deviation }\end{array}$ & 0.54 \\
\hline
\end{tabular}

Table 6.8: Statistical breakdown of quartzite blades

Layer F/G: Bladelets

\begin{tabular}{|c|c|c|c|c|c|}
\hline \multicolumn{7}{|c|}{ Layer F/G Chert Bladelets } \\
\hline \multicolumn{2}{|c|}{ Length } & \multicolumn{2}{c|}{ Width } & \multicolumn{2}{c|}{ Thickness } \\
\hline Mean & 24.89 & Mean & 8.41 & Mean & 3.35 \\
\hline Median & 22.41 & Median & 7.84 & Median & 2.81 \\
\hline Mode & 15.4 & Mode & 16.9 & Mode & 1.57 \\
\hline $\begin{array}{c}\text { Standard } \\
\text { Deviation }\end{array}$ & 12.22 & $\begin{array}{l}\text { Standard } \\
\text { Deviation }\end{array}$ & 4.7 & $\begin{array}{c}\text { Standard } \\
\text { Deviation }\end{array}$ & 1.9 \\
\hline
\end{tabular}

Table 6.9: Statistical breakdown of chert bladelets

\begin{tabular}{|c|c|c|c|c|c|}
\hline \multicolumn{7}{|c|}{ Layer F/G: Quartz Bladelets } \\
\hline \multicolumn{2}{|c|}{ Length $(\mathrm{mm})$} & \multicolumn{2}{|c|}{ Width $(\mathrm{mm})$} & \multicolumn{2}{|c|}{ Thickness $(\mathrm{mm})$} \\
\hline Mean & 15.9 & Mean & 6.66 & Mean & 3.36 \\
\hline Median & 16.6 & Median & 7.02 & Median & 3.19 \\
\hline Mode & \#N/A & Mode & \#N/A & Mode & \#N/A \\
\hline $\begin{array}{l}\text { Standard } \\
\text { Deviation }\end{array}$ & 3.23 & $\begin{array}{c}\text { Standard } \\
\text { Deviation }\end{array}$ & 1.67 & $\begin{array}{c}\text { Standard } \\
\text { Deviation }\end{array}$ & 1.22 \\
\hline
\end{tabular}

Table 6.10: Statistical breakdown of quartz bladelets

\begin{tabular}{|c|c|c|c|c|c|}
\hline \multicolumn{7}{|c|}{ Layer F/G: Quartzite Bladelets } \\
\hline \multicolumn{2}{|c|}{ Length $(\mathrm{mm})$} & \multicolumn{2}{|c|}{ Width $(\mathrm{mm})$} & \multicolumn{2}{c|}{ Thickness $(\mathrm{mm})$} \\
\hline Mean & 30.45 & Mean & 12.47 & Mean & 6.82 \\
\hline Median & 29.96 & Median & 11.3 & Median & 5.36 \\
\hline Mode & \#N/A & Mode & \#N/A & Mode & \#N/A \\
\hline $\begin{array}{c}\text { Standard } \\
\text { Deviation }\end{array}$ & 10.87 & $\begin{array}{c}\text { Standard } \\
\text { Deviation }\end{array}$ & 4.05 & $\begin{array}{c}\text { Standard } \\
\text { Deviation }\end{array}$ & 4.13 \\
\hline
\end{tabular}

Table 6.11: Statistical breakdown of quartzite bladelets 


\section{Layer F/G Burin Spalls:}

\begin{tabular}{|c|c|c|c|c|c|}
\hline \multicolumn{7}{|c|}{ Layer F/G Chert Burin Spalls } \\
\hline Length $(\mathrm{mm})$ & \multicolumn{2}{|c|}{ Width $(\mathrm{mm})$} & \multicolumn{2}{c|}{ Thickness $(\mathrm{mm})$} \\
\hline Mean & 14.72 & Mean & 4.34 & Mean & 3.1 \\
\hline Median & 14.01 & Median & 4 & Median & 2.56 \\
\hline Mode & \#N/A & Mode & 4 & Mode & 1.91 \\
\hline $\begin{array}{c}\text { Standard } \\
\text { Deviation }\end{array}$ & 6.804 & $\begin{array}{l}\text { Standard } \\
\text { Deviation }\end{array}$ & 2.23 & $\begin{array}{l}\text { Standard } \\
\text { Deviation }\end{array}$ & 1.53 \\
\hline
\end{tabular}

Table 6.12: Statistical breakdown of chert burin spalls

\begin{tabular}{|c|c|c|c|c|c|}
\hline \multicolumn{5}{|c|}{ Layer F/G Quartz Burin Spalls } \\
\hline Length $(\mathrm{mm})$ & \multicolumn{2}{c|}{ Width $(\mathrm{mm})$} & \multicolumn{2}{l|}{ Thickness $(\mathrm{mm})$} \\
\hline Mean & 9.69 & Mean & 4.22 & Mean & 3.04 \\
\hline Median & 9.6 & Median & 4.03 & Median & 2.38 \\
\hline Mode & \#N/A & Mode & \#N/A & Mode & \#N/A \\
\hline $\begin{array}{c}\text { Standard } \\
\text { Deviation }\end{array}$ & 3.48 & $\begin{array}{l}\text { Standard } \\
\text { Deviation }\end{array}$ & 1.87 & $\begin{array}{l}\text { Standard } \\
\text { Deviation }\end{array}$ & 1.58 \\
\hline
\end{tabular}

Table 6.13: Statistical breakdown of quartz burin spalls

\begin{tabular}{|c|c|c|c|c|c|}
\hline \multicolumn{7}{|c|}{ Layer F/G: Quartzite Burin Spalls } \\
\hline \multicolumn{2}{|c|}{ Length $(\mathrm{mm})$} & \multicolumn{2}{|c|}{ Width $(\mathrm{mm})$} & \multicolumn{2}{|c|}{ Thickness $(\mathrm{mm})$} \\
\hline Mean & 13.2 & Mean & 4.45 & Mean & 3.86 \\
\hline Median & 10.78 & Median & 4.04 & Median & 3.125 \\
\hline Mode & \#N/A & Mode & \#N/A & Mode & \#N/A \\
\hline $\begin{array}{c}\text { Standard } \\
\text { Deviation }\end{array}$ & 7.57 & $\begin{array}{c}\text { Standard } \\
\text { Deviation }\end{array}$ & 1.27 & $\begin{array}{c}\text { Standard } \\
\text { Deviation }\end{array}$ & 2.49 \\
\hline
\end{tabular}

Table 6.14: Statistical breakdown of quartzite burin spall 


\section{2: IMAGERY APPENDIX}

$\underline{\text { Cores }}$

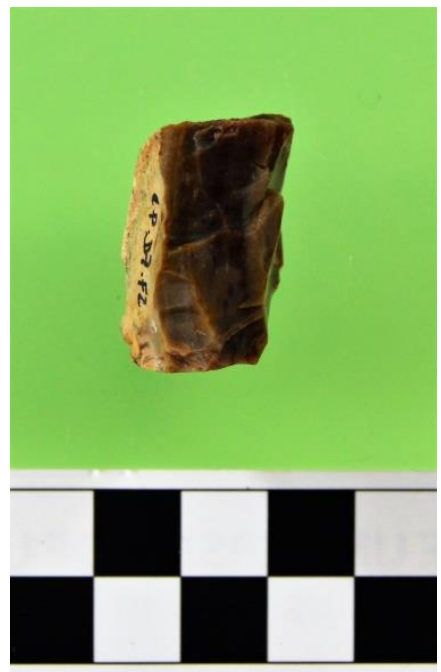

Chert; Prismatic Core

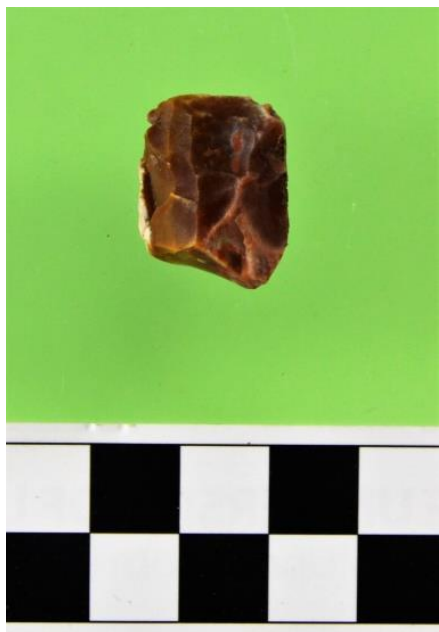

Chert; Prismatic Core

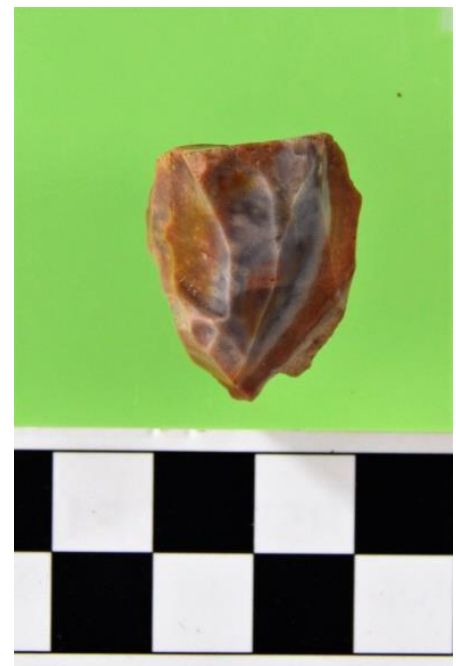

Chert; Prismatic Core

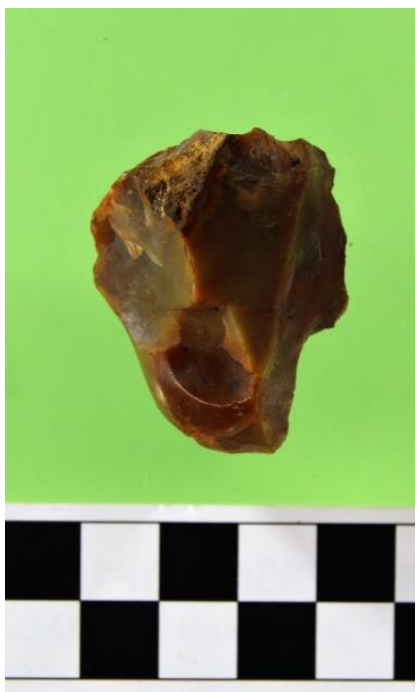

Chert; Multidirectional Core 


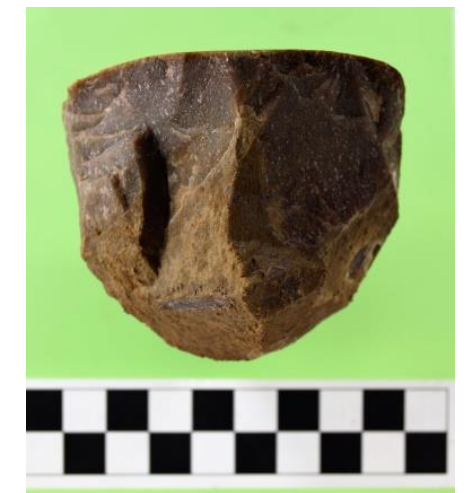

Quartzite; Prismatic Core

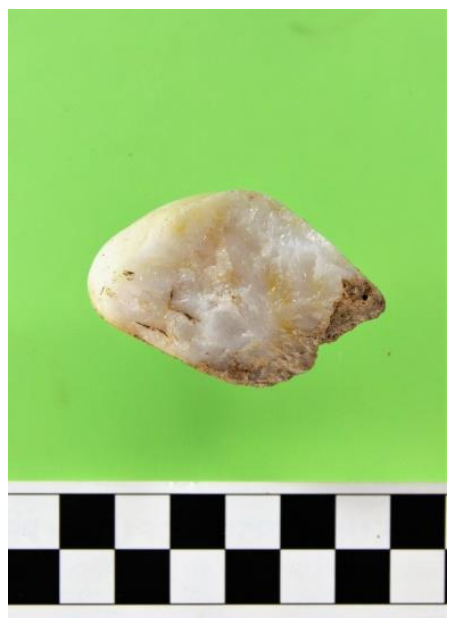

Quartz; Prismatic Core
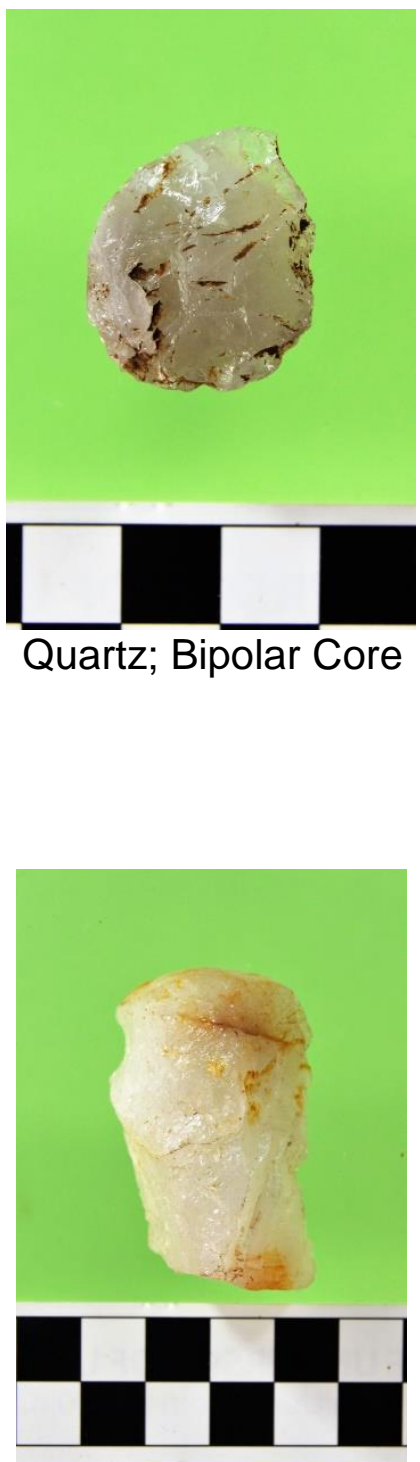

Quartz; Core Fragment 


\section{Unretouched Blanks}

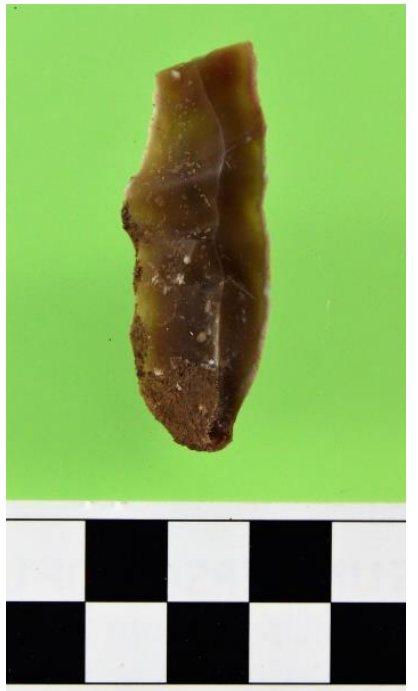

Chert; Blade/bladelet Fragment

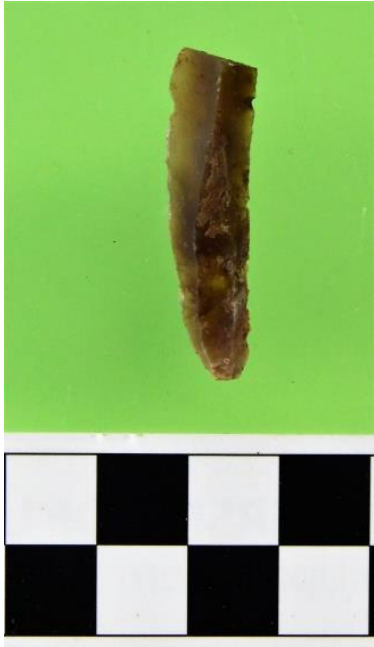

Chert; Bladelet
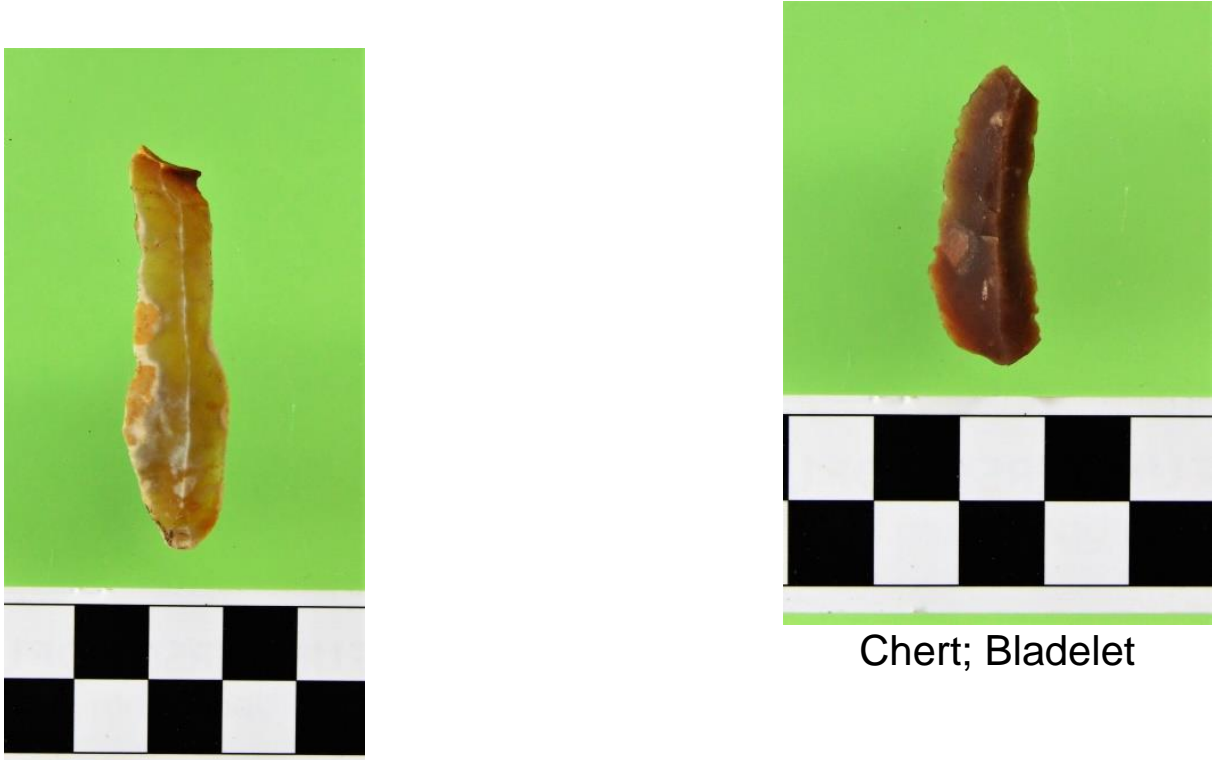

Chert; Bladelet

Chert; Bladelet 

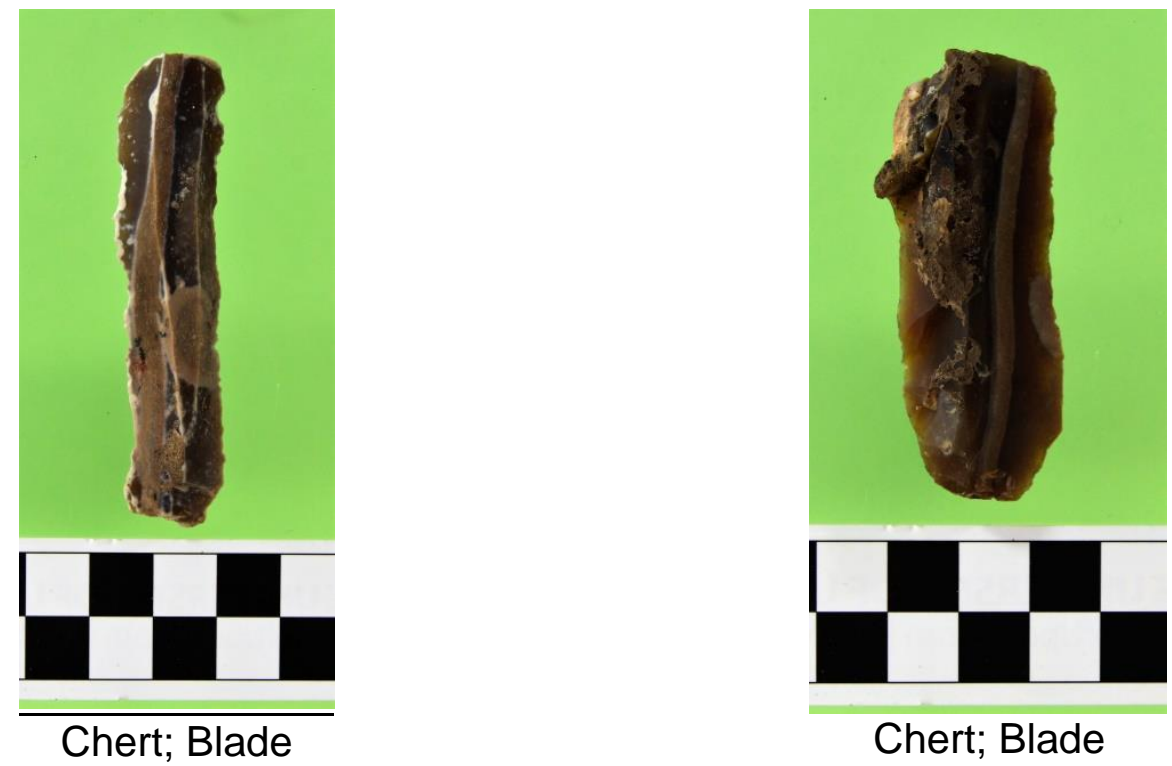

$\underline{\text { Preparatory and Maintenance Products }}$

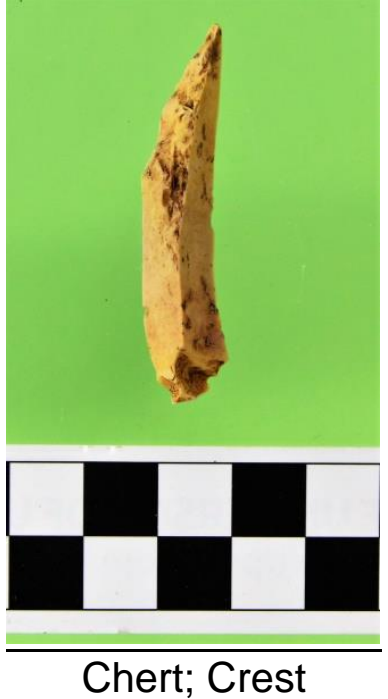




\section{Retouched Tools}

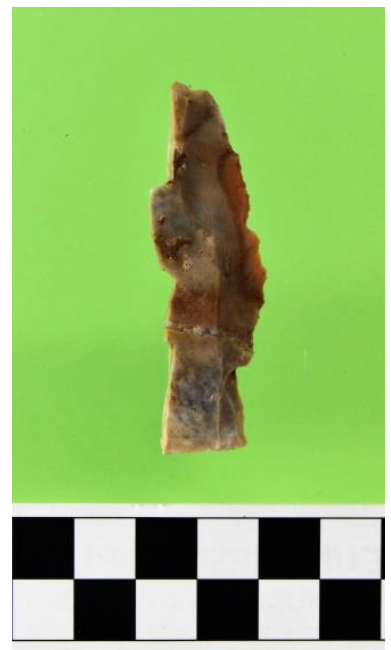

Chert; Burin

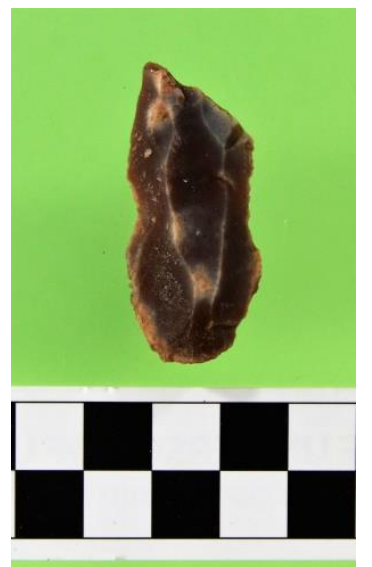

Chert; Burin
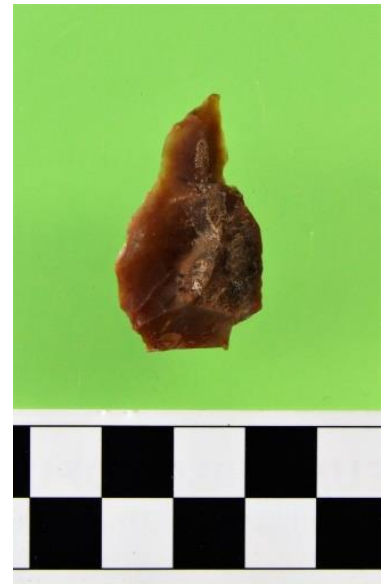

Chert; Burin

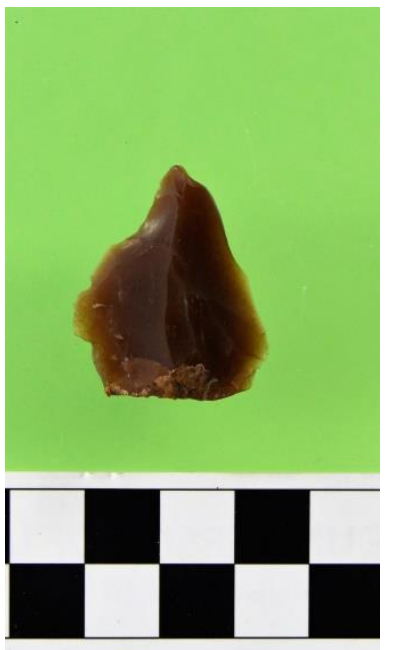

Chert; Burin

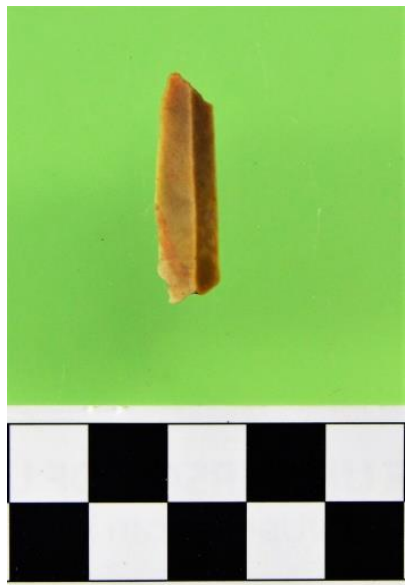

Chert; Truncation

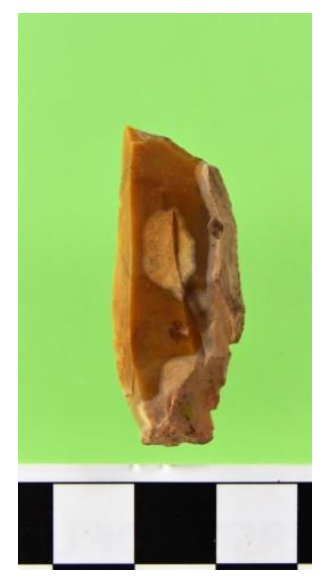

Chert; Truncation 

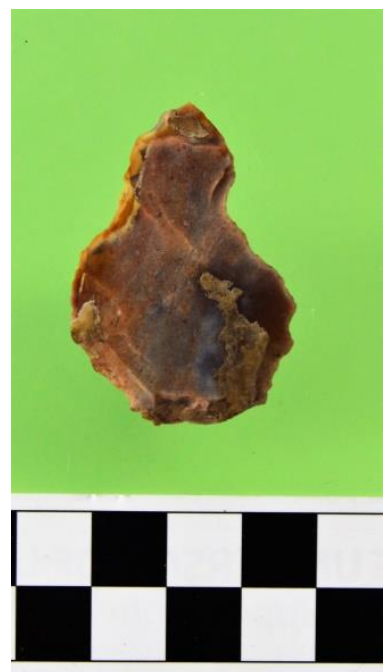

Chert; Side Scraper

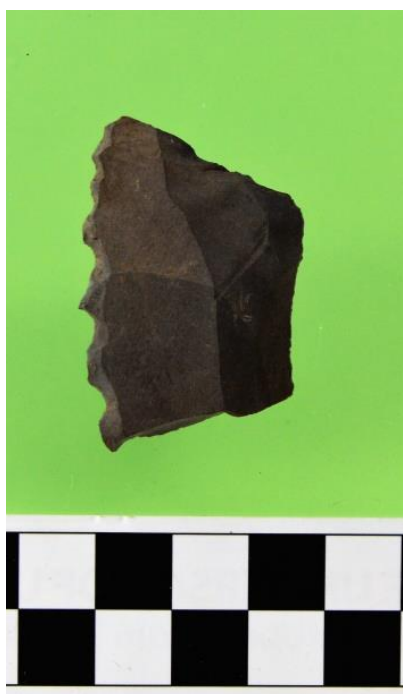

Quartzite; Denticulate

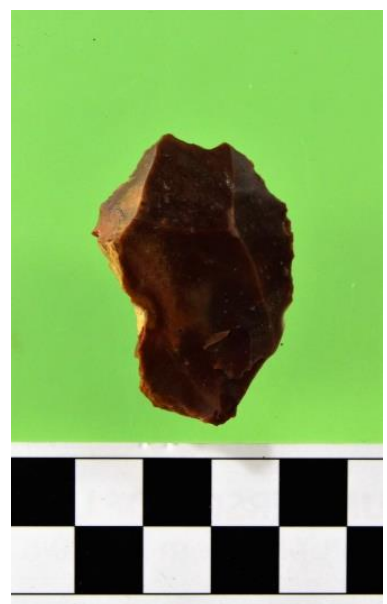

Chert; Notch
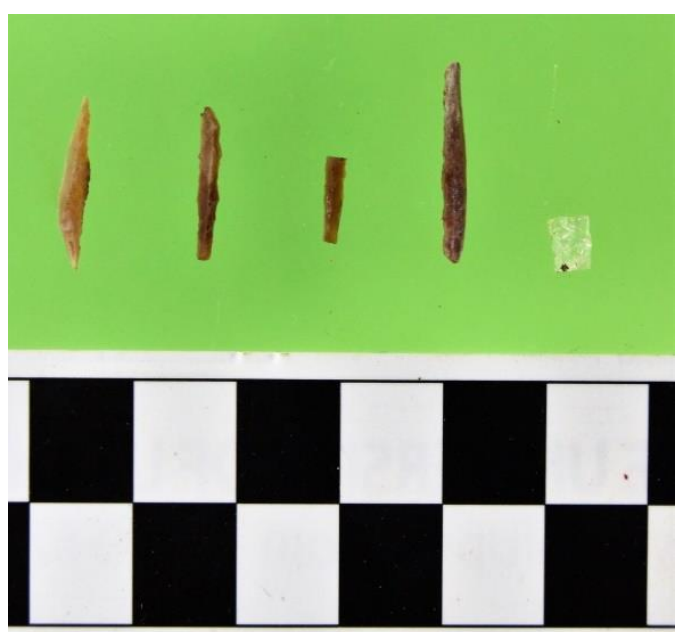

Chert (\#4) and Quartz (\#1); Backed

Bladelet

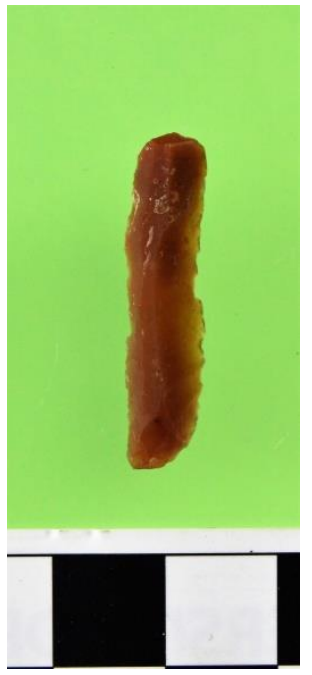

Chert; Backed Bladelet

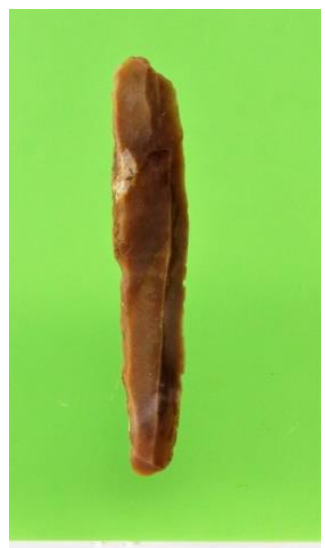

Chert; Backed Bladelet 


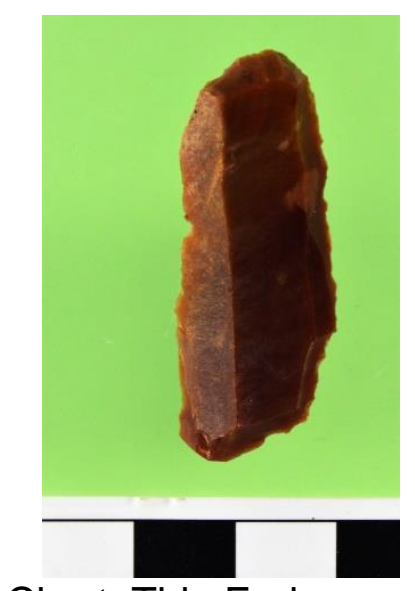

Chert; Thin Endscraper

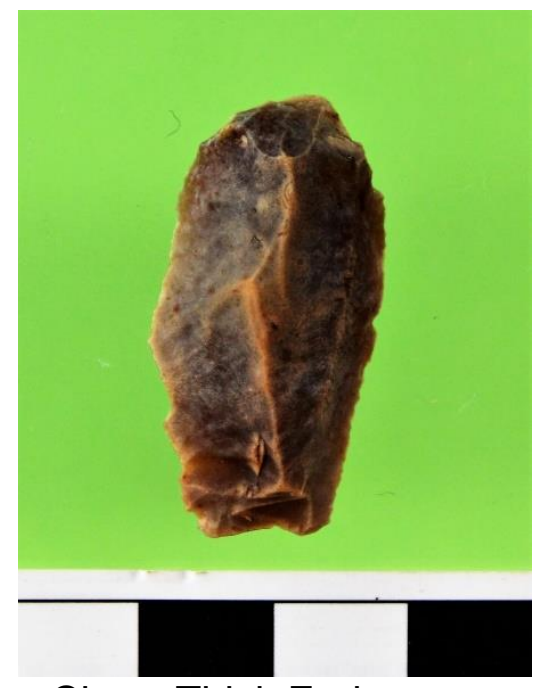

Chert; Thick Endscraper

\section{$\underline{\text { Chips }}$}

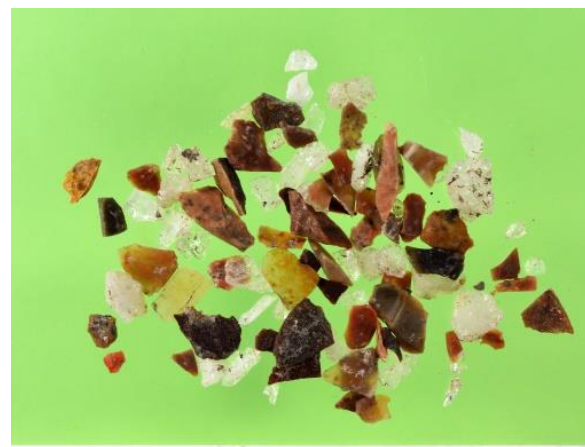

I

$\underline{\text { Refits }}$
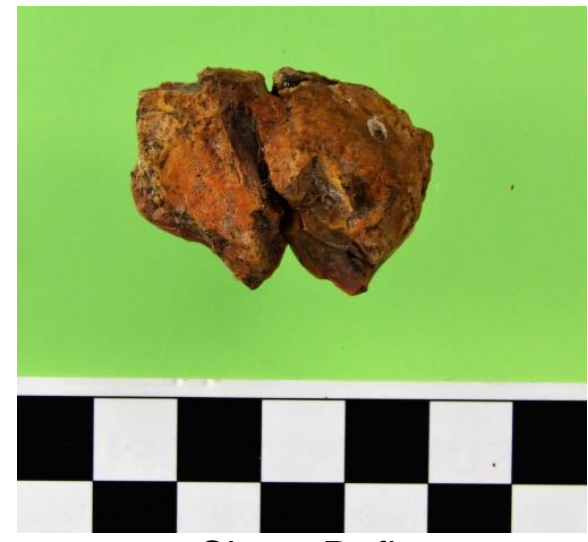

Chert; Refit 


\title{
CURRICULUM VITAE
}

\author{
MELISSA J. HOLST \\ 8311 Locust Drive, Charlestown, IN 47111 \\ Melissa.Jean.Holst@gmail.com \\ (502) 345-6703
}

\section{Higher Education Experience}

Master of Arts in Anthropology

GPA: 4.0

University of Louisville, Louisville, Kentucky

May 2017

Bachelor of Arts in Anthropology

GPA: 3.2

University of Louisville, Louisville, Kentucky

May 2013

\section{Research and Teaching Experience}

Graduate Research Assistant

University of Louisville Archaeology Laboratory

Philip DiBlasi

August 2016-May 2017

Conducted independent research

- Assisted students with research projects and laboratory exercises

- Assisted in the preservation and management of cultural resources stored at the laboratory

Graduate Teaching Assistant

Ceramics

University of Louisville Archaeology Laboratory

Dr. Anna Browne Ribeiro

January 2017-May 2017

- Assisted in instructing class lectures and demonstrations

- Coached students in laboratory identification and analysis techniques

- Instructed independent study sessions 
Graduate Teaching Assistant

Lithics

University of Louisville Archaeology Laboratory

Dr. Amanuel Beyin

August 2016-December 2016

- Assisted in instructing class lectures and demonstrations

- Coached students in hands-on knapping experiments

- Instructed independent study sessions

Archaeological Excavation

Lapa do Picareiro, Central Portugal

Dr. Jonathan Haws

July 2012-August 2016

This project is titled Neanderthal and Modern Human Response to Environmental Change at the Middle-Upper Paleolithic Transition, Lapa do Picareiro, Portugal. The site has been under excavation by Dr. Jonathan Haws since 2005 and it contains roughly 10 meters of sediments spanning about 50,000 years. Excavation of the site is continuing to produce high resolution data sets pertaining to site function, lithic technological organization, and subsistence practices. This project has been funded by the National Science Foundation, the Wenner-Gren Foundation for Anthropological Research, the Archaeological Institute of America, the National Geographic Society, and the University of Louisville. During this project I assisted in excavation, manual screening of sediment, laboratory processing of recovered materials, faunal and lithic analysis, and total station set-up and data recording.

Archaeological Survey

June 2013-July 2013

Southwestern Coast of Portugal

Dr. Jonathan Haws

This project was titled Human responses to late Pleistocene environmental change in the coastal zone of Portuguese Estremadura. The project involved geoarchaeological survey of the coastal region between São Pedro de Muel and Peniche, with the goal of finding evidence of coastal settlements during the Paleolithic. This project was funded by the National Science Foundation. During this project I assisted in systematic pedestrian survey, artifact identification, excavation of test pits, and laboratory processing of recovered artifacts. 
Laboratory Research and Analysis

University of Algarve Archaeology Laboratory, Faro, Portugal

Dr. Telmo Pereira

December 2015, June 2016

This study was conducted as part of an ongoing independent Master's thesis research project. It involved the macroscopic and microscopic analysis of a previously unstudied late Magdalenian lithic assemblage recovered from the cave site of Lapa do Picareiro in Portugal. This project was funded by the University of Louisville Anthropology Department Research Fund, University of Louisville Portuguese Studies Fund, Graduate Student Council Research and Travel Fund Grants, and the Graduate Network in the Arts and Sciences Graduate Research Grant. During this study I was responsible for the analysis and identification and curation of each artifact within the assemblage. After analysis, each artifact was then coded and put into a database that I created for the study.

\section{Completed/Presented Works}

"New Data on Late Magdalenian Lithic Technological Organization at Lapa do Picareiro" with Dr. Jonathan Haws, poster presented at the Society for American Anthropology Annual Meeting in Orlando, Florida, April 2016.

"Late Magdalenian Lithic Technological Organization: New Data from Lapa do Picareiro, Portugal" with Dr. Jonathan Haws, poster presented at the Graduate Student Regional Research Conference in Louisville, Kentucky, April 2016.

"Late Magdalenian Lithic Technology at Lapa do Picareiro, Central Portugal" with Dr. Jonathan Haws, poster to be presented at the Graduate Student Regional Research Conference in Louisville, Kentucky, March 2017.

"Late Magdalenian Lithic Technology at Lapa do Picareiro, Central Portugal" with Dr. Jonathan Haws, poster to be presented at the Society for American Anthropology Annual Meeting in Vancouver, B.C., Canada, March 2017.

"Late Magdalenian Lithic Technological Organization at Lapa do Picareiro, Central Portugal." Thesis submitted to the Faculty of the College of Arts and Sciences of the University of Louisville in Partial Fulfillment of the Requirements for the Degree of Master of Arts. April 2017. 


\section{Honors and Awards}

Graduate Research Assistantship

2016-2017

Graduate Student Council Travel Fund Grant

2016, 2017

Portuguese Studies Program Travel Grant

2012, 2013, 2015, 2016

Graduate Student Council Research Fund Grant

2015

Anthropology Departmental Research Grant

2015

Graduate Network in Arts and Sciences Graduate Student Research Grant 2015

\section{Professional Development Experience}

School of Arts and Sciences Research Spotlight 2017

Kentucky Academy of Science $102^{\text {nd }}$ Annual Meeting Volunteer 2016

Paleoanthropology Society Annual Meeting Attendee 2017

Society of American Archaeology Annual Conference Attendee 2016, 2017

Kentucky Heritage Council Archaeology Annual Conference Attendee 2017

Graduate Student Regional Research Conference Attendee

2016, 2017

Anthropology Graduate Student Association Secretary

2016-2017

Grant Writing Academy Member

2015

Publishing Academy Member

2016

Graduate Teaching Assistantship Academy

\section{Professional Society Memberships}

(From - Until)

Kentucky Academy of Science

2017 - Current

Paleoanthropology Society

2017 - Current

Archaeological Institute of America

2012 - Current

Society for American Archaeology

2015 - Current

Lambda Alpha Anthropological Honors Society

2012 - Lifetime

Sigma Alpha Lambda Leadership Honors Society

2012 - Lifetime

Golden Key International Honors Society

2012 - Lifetime

Tau Sigma Honor Society for Transfer Students

2012 - Lifetime 